\title{
La fundación arcaica de Gadir. La construcción historiográfica de una ciudad ¿real o inventada?*
}

\section{Gadir archaic foundation. An historiographic construction of a city: real or invented?}

\author{
Ana M. ${ }^{a}$ Niveau de Villedary y Mariñas ${ }^{1}$ \\ Departamento de Historia, Geografía y Filosofía. Universidad de Cádiz
}

\begin{abstract}
Aquí está la ciudad de Gadir, [... ]
ciudad grande y opulenta en tiempos antiguos;

ahora es pobre, ahora pequeña,

ahora abandonada, ahora un montón de ruinas.
\end{abstract}

Avieno, O. M., 269-272

\section{RESUMEN}

La investigación de la antigua ciudad fenicia de Gadir ha estado condicionada históricamente por la falta de evidencias materiales urbanas, lo que ha propiciado que durante siglos se fijara una imagen en extremo idealizada de la ciudad basada en la lectura acrítica de los testimonios literarios y su (re) interpretación por la historiografía posterior. El panorama cambia a raíz del hallazgo de materiales, contextos y secuencias estratigráficas de época arcaica que permiten la reconstrucción de lo que hubo de ser la ciudad fenicia a partir de la evidencia científica y no desde el anhelo de lo "imaginado". A pesar de ello la tendencia a recrear una ciudad más deseada que real se mantiene aún viva entre ciertos sectores, a los que les cuesta renunciar a esta secular "tradición inventada", entendida esta en los términos acuñados por Hobsbawm.

\footnotetext{
* Este trabajo ha sido realizado gracias a una estancia de investigación en la Universidad de Oxford entre los meses de febrero y abril de 2017 dentro del Programa "Salvador de Madariaga" del Plan Estatal de Investigación Científica, Técnica e Innovadora (2013-2016) del Ministerio de Educación, Cultura y Deporte, y se inscribe en el marco de actuación del Grupo de Investigación HUM-509 del PAIDI (PHOENIX MEDITERRA$N E A$. Protohistoria de Andalucía Occidental) y del Campus Internacional de Excelencia del Mar (CEIMar).

Hace tiempo que acostumbro a comenzar los trabajos de corte historiográfico reivindicando la figura de Juan Ramón Ramírez Delgado, historiador y arqueólogo, investigador curioso, pionero, profundo conocedor de la historia y de la historiografía de la ciudad, de sus entresijos y de su intrahistoria, persona en extremo amable y locuaz, siempre dispuesto a compartir su sabiduría y, no obstante, tan olvidado en el mundo científico y académico. Su obra "Los primitivos núcleos de asentamiento de la ciudad de Cádiz", publicado por el Consistorio gaditano en 1982, debía ser libro de cabecera para todos
}

\section{SUMMARY}

The research on the ancient Phoenician city of Gadir has been historically conditioned by the lack of urban material evidences. This circumstance has led for centuries to the developing of an extremely idealized image of the city based on the uncritical reading of classical literary testimonies and their (re) interpretation by subsequent historiography. However, the situation have changed after the new findings of materials, contexts and stratigraphic sequences of the Archaic period, since they allow us to reconstruct, from a scientific basis rather than from the "imagined", what it might be the Phoenician city. Nevertheless, the tendency to recreate a city more imaginary than real is still alive in certain sectors unwilling to abandon this secular "invented tradition", in the sense of the expression coined by Hobsbawn.

PALABRAS CLAVE: Gadir; colonización fenicia; ciudad arcaica; historiografía; Historia idealizada vs. Historia científica.

KEY WORDS: Gadir; Phoenician colonization; archaic city; historiography; idealizing History vs. scientific History.

COMO CITAR ESTE ARTÍCULO / CITATION: Niveau de Villedary y Mariñas, A. M. ${ }^{a} 2019$ : "La fundación arcaica de Gadir. La construcción historiográfica de una ciudad ¿real o inventada?", Archivo Español de Arqueología 92, 7-41. https://doi.org/10.3989/aespa.092.019.001

aquellos que aspiramos a rescatar un trozo de la historia de la ciudad. Por ello, y una vez más, gracias Juan Ramón.

1 anamaria.niveau@uca.es / ORCID iD: https://orcid. org/0000-0002-8888-1169

Copyright: () 2019 CSIC. Este es un artículo de acceso abierto distribuido bajo los términos de una licencia de uso y distribución Creative Commons Reconocimiento 4.0 Internacional (CC-by 4.0). 


\section{LA IMAGEN MÍTICA DE GADIR COMO CONSTRUCTO HISTORIOGRÁFICO}

Según la tradición, Gadir fue fundada por los fenicios de Tiro 80 años después de la caída de Troya (ca. 1104-1003 a. C.) en el lugar donde hoy se sitúa la actual ciudad de Cádiz (suroeste de España, latitud: 36 $32^{\circ} 01^{\prime \prime} \mathrm{N}$, longitud: $06^{\circ} 17^{\prime} 58^{\prime}$ 'W), en el extremo occidente del Mediterráneo (Veleyo Paterculo, Hist. Rom, I, 2, 3 y I, 8, 4; Estrabón, I, 3, 2; Mela, III, 6, 46; Plinio, N.H., XIX, 216; Pseudo-Aristóteles, De mirabil. ausc. 134) (Fig. 1).

La leyenda de la fundación que recoge Estrabón (III, 5, 5) da buena fe de la gran antigüedad que para los habitantes de la propia ciudad tendría no solo esta, sino también el templo dedicado a Melqart, levantado al mismo tiempo por los tirios en el extremo sur del archipiélago original (Fig. 2). Una idea, la de la dualidad ciudad-templo, que permanece inmutable en el tiempo y que ha contribuido a fijar la localización de ambos en los lugares tradicionales: al norte la ciudad, en los alrededores del punto topográfico más alto de la misma (donde se ubica el Palacio de los Marqueses de Recaño-Torre Tavira) y en el extremo meridional el templo, en los alrededores del actual islote de Sancti Petri, respectivamente.
En cuanto a la antigua topografía, los autores clásicos coinciden en describir un archipiélago. Según Plinio (HN IV, 36, 120), la ciudad fenicia se encontraba en la isla pequeña (llamada Erytheia, Afrodisias o isla de Iuno), situada al norte y consagrada a Venus Marina (Avieno, OM, 319-317), posiblemente la fenicia Astarté. Separada por una lengua de mar se encuentra la isla mayor, de forma alargada, llamada Kotinoussa por Timeo (Plinio, HN, IV, 4, 119-120). En esta isla se levantaron los templos dedicados a Kronos (en origen Baal-Hammón) en el extremo norte y a Herakles (el fenicio Melqart) en el sur. Ante la falta de espacio, la ciudad se extiende en época romana a la isla mayor que, en cualquier caso y siempre siguiendo a Estrabón, nunca debió ser de dimensiones considerables, si tenemos en cuenta que el propio geográfo griego se hace eco de las reducidas dimensiones del orbe, incluso después de la ampliación de Balbo (Estrabón III, 5, 3).

El análisis crítico de las (escasas y sesgadas) noticias sobre los orígenes y la situación de la ciudad fenicia pone de relieve la falta de atención que los escritores griegos prestaron a la realidad del Extremo Occidente, que entienden como un territorio límite que solo interesa como parte de una estrategia de mitificación que convierte todos los confines del mundo conocido en territorios ignotos, poblados por seres mitológicos y

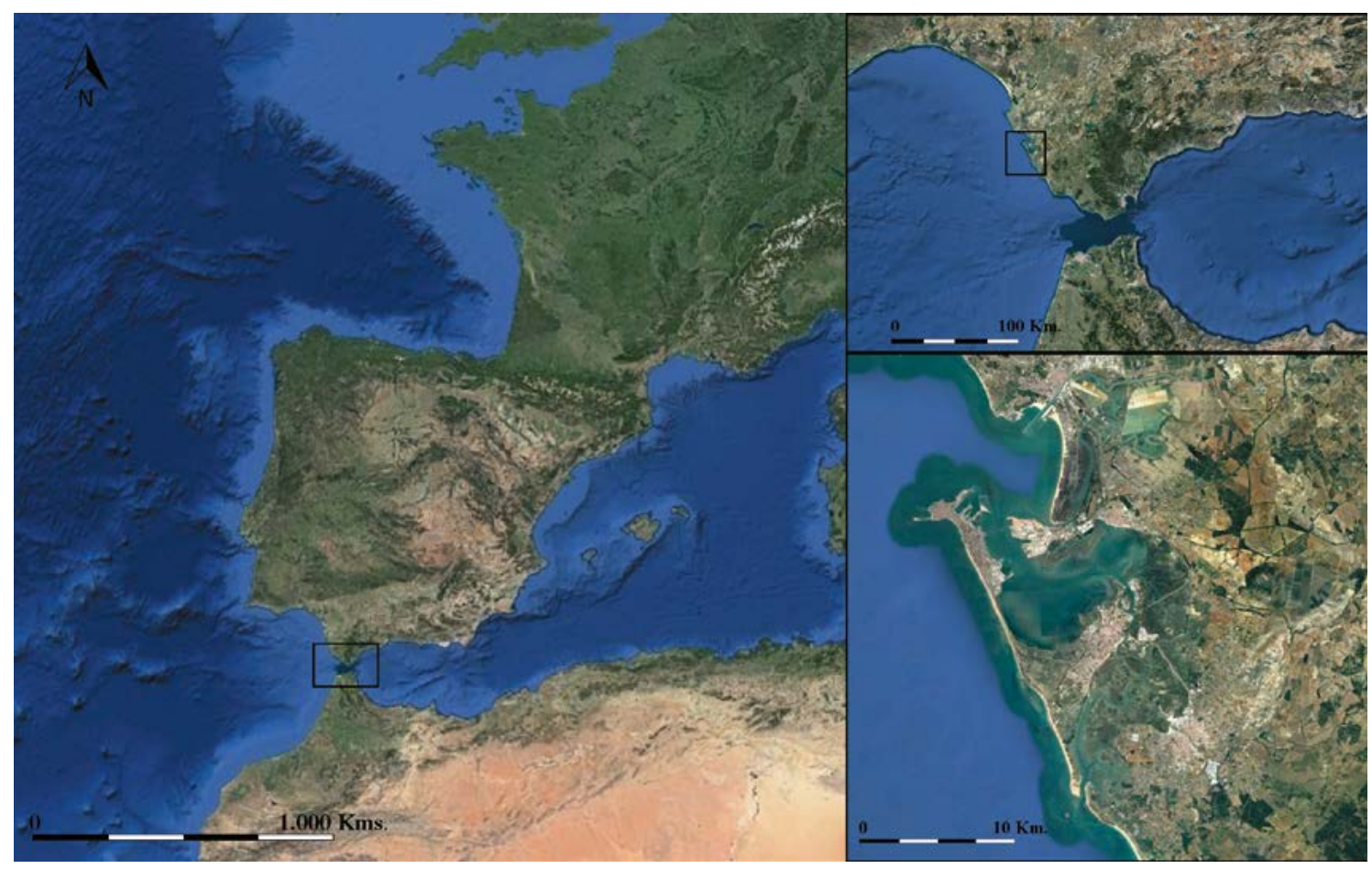

Figura 1. Localización de la ciudad de Cádiz (España) (@ autora, a partir de Google Earth). 


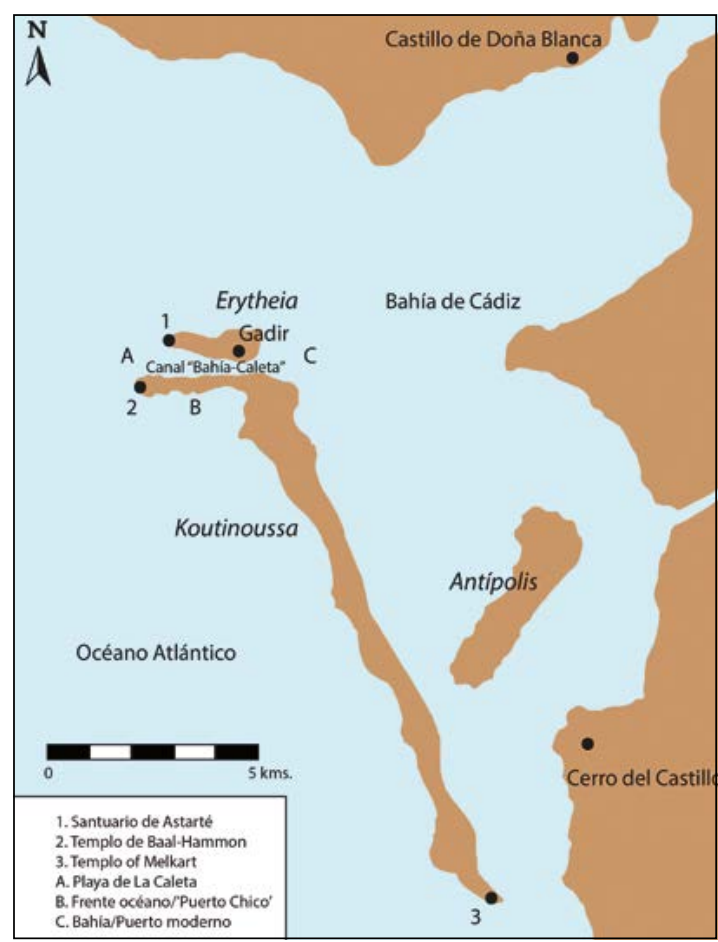

Figura 2. Paleotopografía de la bahía de Cádiz en época fenicia, con identificación de las islas citadas por las fuentes escritas (Erytheia, Koutinoussa y Antipolis), los templos (Afrodita/ Venus Marina/Astarte, Baal-Hammon/Kronion, Melqart/ Herakleion), el núcleo urbano insular (Gadir) y los asentamientos continentales (Castillo de Doña Blanca, El Puerto de Santa María y Cerro del Castillo, Chiclana de la Frontera) (@ autora).

bárbaros. Un escenario propicio para situar algunas de las hazañas de Herakles, el héroe colonizador por antonomasia (Fernández Camacho 2015), característica esta que le lleva, en muchas ocasiones, a sincretizarse de forma casi automática con la divinidad fenicia.

La importancia de la ciudad que reflejan las fuentes clásicas pervive desdibujada (y manipulada según los intereses de cada época) ${ }^{2}$ en la tradición literaria posterior (Fernández Camacho 2016). Los autores de época moderna y contemporánea (entre los que cabe destacar a Agustín de Horozco, Juan Bautista Suárez de Salazar, Fray Jerónimo de la Concepción, Adolfo de Castro y, más recientemente, a Adolf Schulten, César Pemán o Antonio García y Bellido) se hacen eco tanto del origen fenicio de la ciudad como de la grandeza

${ }^{2}$ El tratamiento que los historiadores medievales y modernos hacen de la Gadir fenicia bascula entre dos extremos no siempre reconciliables: el prestigio que le confiere ser "la ciudad más antigua de Occidente", por una parte, y la valoración negativa de sus "protagonistas": fenicios y cartagineses, por otra (Fernández Camacho 2016). de la misma en la Antigüedad, pese a que la información que transmiten es confusa y sesgada (Ramírez Delgado 1982: 30-41; Niveau de Villedary 2010: 629630). No existe unanimidad y sí en cambio numerosas inexactitudes en relación con la configuración del antiguo archipiélago, los nombres que reciben las islas, sus dimensiones y la propia situación de las mismas; fruto de la profunda transformación sufrida por el espacio físico durante este tiempo y de la casi absoluta pérdida de vestigios arqueológicos monumentales por la ocupación continuada del solar urbano a través de los siglos. En estas primeras etapas historiográficas los hallazgos arqueológicos son de carácter fortuito y aislados (Ramírez Delgado 1982: 100, n. 120) y lejos de clarificar el panorama no hacen más que contribuir a su confusión, al atribuirse a época fenicia restos de naturaleza romana e, incluso, posteriores.

Desde momentos tempranos se afianza en el imaginario colectivo la creencia de la antigüedad de la ciudad, su origen trimilenario, la filiación fenicia y su esencia de cuna de la civilización en Occidente (Delgado 2008: 385; Niveau de Villedary 2010: 630), hasta el punto que el escudo de la villa incorpora como motivo central al dios Herakles-Hércules (identidades clásicas del fenicio Melqart) sosteniendo las dos columnas que representan las puertas de Occidente (Fig. 3). Este empeño en sancionar un origen lejano y

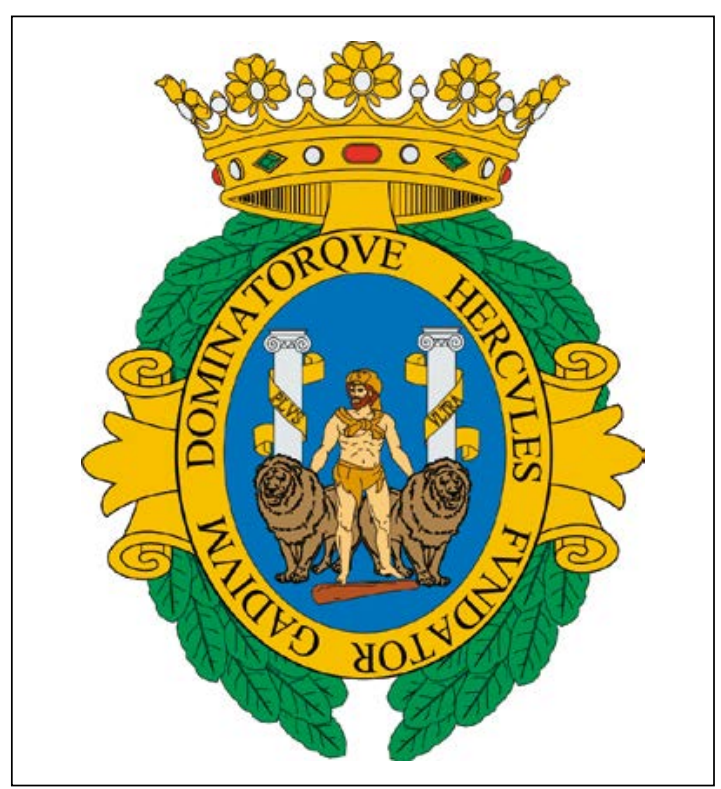

Figura 3. Escudo de la actual ciudad de Cádiz (España). Hércules acompañado por dos leones y por las columnas que simbolizan el Estrecho de Gibraltar, con la leyenda "Non plus ultra” (No más allá) y el lema "Hercules Fundator Gadium Dominatorque " ("Hércules dominador y fundador de Cádiz") (recuperado de: https://es.wikipedia.org/wiki/Cádiz). 


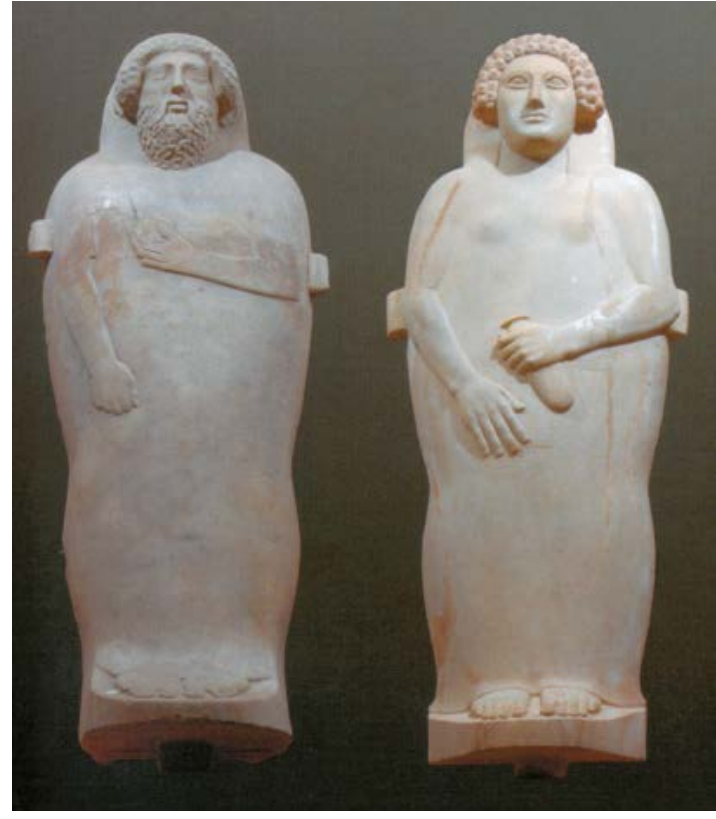

1

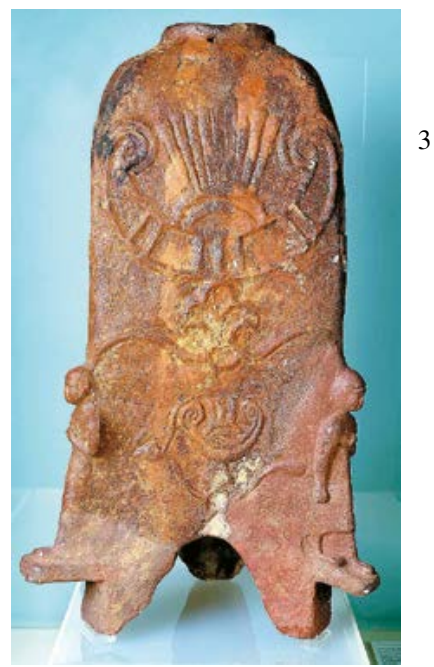

3
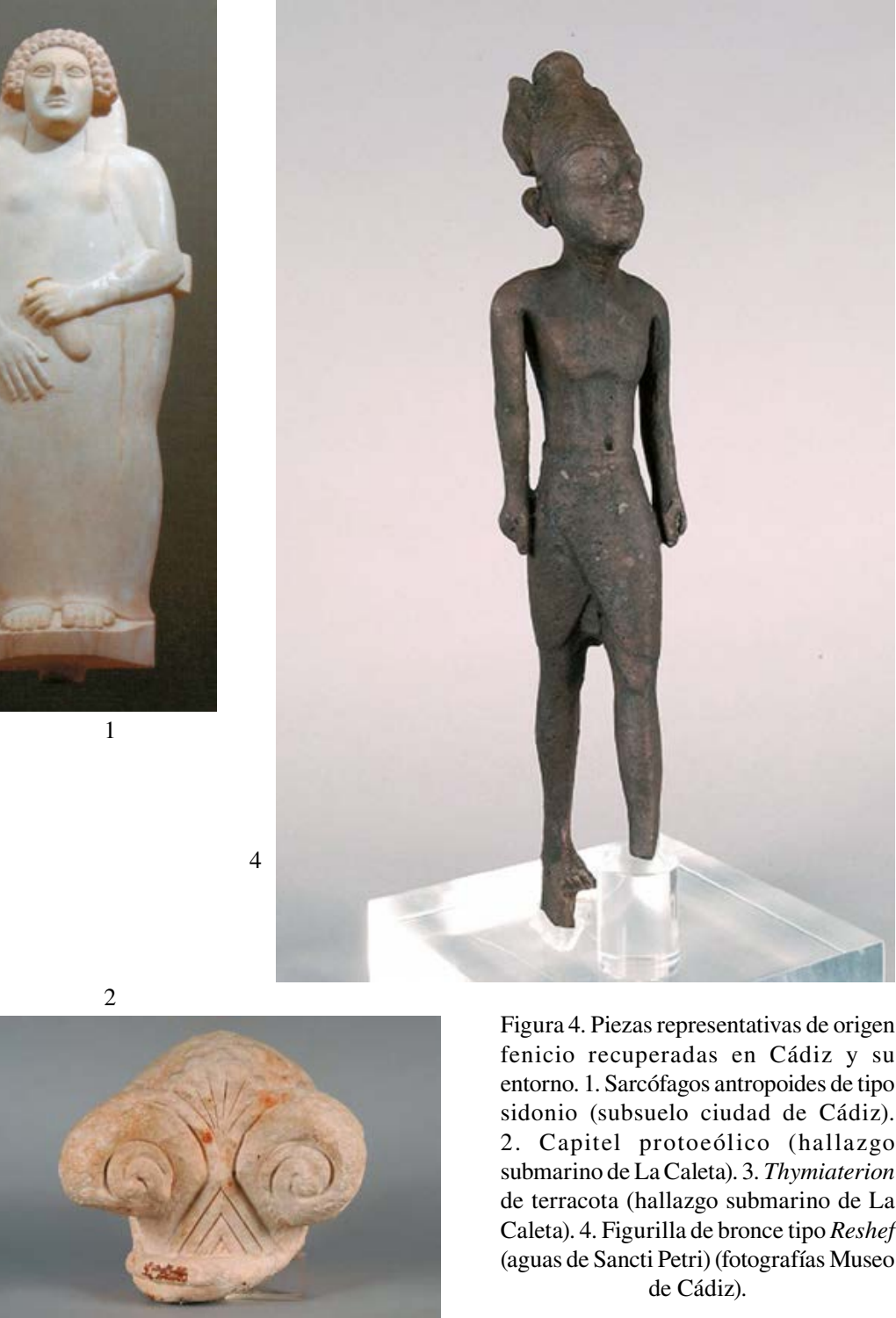

Figura 4. Piezas representativas de origen fenicio recuperadas en Cádiz y su entorno. 1. Sarcófagos antropoides de tipo sidonio (subsuelo ciudad de Cádiz). 2. Capitel protoeólico (hallazgo submarino de La Caleta). 3. Thymiaterion de terracota (hallazgo submarino de La Caleta). 4. Figurilla de bronce tipo Reshef (aguas de Sancti Petri) (fotografías Museo de Cádiz). prestigioso, tan arraigado como vago, ha perdurado en el tiempo impregnando a la ciudad y a sus habitantes de un a veces mal entendido orgullo histórico que, en ocasiones, llega a ser chovinista ${ }^{3}$; aunque, por otra

3 Defender la existencia de procesiones náuticas en honor a Isis a partir de las terracotas de procedencia subacuática halladas en los alrededores de la Punta del Nao, es de por sí aventurado, pero considerar estas como "la constatación de que en Cádiz se celebraba ya el carnaval en el s. VI a. C." (Abad y Corzo 2017: 95), la fiesta gaditana por antonomasia en la actualidad, aunque sugerente, es una afirmación presentista y forzada que no se ajusta a la realidad. Pese a ello ilustra a la perfección esa búsqueda de los orígenes de la ciudad y sus costumbres en un pasado remoto ( $y$, en consecuencia, prestigioso) de la que venimos hablando. parte, en la cara positiva ha favorecido el interés de la ciudadanía por los restos arqueológicos de la ciudad, por su preservación (salvo en épocas puntuales, donde prevalecieron otros intereses bajo el «boom» constructivo), por su conocimiento y estudio y por su puesta en valor; asumiendo como propia la historia de la ciudad (Abad y Corzo 2017: 89). En este proceso de "invención de la tradición" (Hobsbawn y Ranger 2002) las piezas fenicias más representativas se han llegado a convertir en símbolos reconocidos (y reconocibles) de la ciudad. Es el caso de los sarcófagos antropoides, el capitel protoeólico, las terracotas halladas bajo las aguas de La Caleta o los bronces procedentes de Sancti Petri, entre otros (Fig. 4, Apéndice I). 


\section{LOS COMIENZOS DEL S. XX: ENTRE LA ARQUEOLOGÍA MODERNA Y LA PERDURACIÓN DE LA CIUDAD IDEALIZADA}

El hallazgo casual del sarcófago antropoide masculino de tipo sidonio en 1887 (Fig. 5) da lugar al nacimiento de la arqueología gaditana moderna $(\mathrm{Ni}-$ veau de Villedary 2010: 630-631). No solo impulsa que el Museo Arqueológico se independice del de Bellas Artes del que hasta entonces dependía, sino que contribuye a que la ciudad se incluya en el plan de excavaciones sistemáticas auspiciadas por la ley de Patrimonio de 1911 (en las últimas campañas sustituida por la de 1933) y el posterior Reglamento de 1912 que la regulaba (Gabardón de la Banda 2014). En este contexto tienen lugar hasta catorce campañas arqueológicas (1916-1934) en la necrópolis púnica y romana de Cádiz. Los trabajos se centran extramuros de la ciudad, hacia ambas vertientes de los glacis de la muralla moderna: la que se abre al Atlántico (Playa de los Corrales o de las Mujeres) por el oeste y la orientada hacia la bahía al este. En ambos casos se trata de zonas muy modificadas en la actualidad, aunque tienen en común su uso funerario en la Antigüedad. En el frente abierto al océano la fuerte erosión marina es también la responsable de la aparición fortuita de un buen número de estructuras funerarias, algunas de las cuales fueron intervenidas "de urgencia" en el momento de su aparición, cuando quedaron descubiertas (y en parte destruidas) por la acción del mar (Ramírez Delgado 1982: 174-176). En la vertiente orientada hacia la bahía el fenómeno es el contrario, ya que se trata de un área ganada al mar a mediados del s. XX mediante aportes antrópicos, que ha dejado la antigua línea de costa bastante retranqueada en relación con la actual, si bien los hallazgos son también de naturaleza funeraria. Esta intensa actividad arqueológica se interrumpe a causa de la guerra civil española y, salvo intervenciones aisladas (Jiménez Cisneros 1971), no se reanuda hasta la década de los ochenta, con la consiguiente pérdida de información, que se agrava al tratarse de un periodo de gran auge urbanístico. Sirvan de ejemplo las palabras de M. J. Jiménez Cisneros, a la sazón comisaria local de Arqueología, que se lamenta que "la mayor parte de las veces estos hallazgos se han producido de una manera fortuita, en los cimientos de edificaciones, y estos se han procurado ocultar por los encargados de dichas obras" (1971: 40).

El hecho de que las intervenciones arqueológicos de esos años se programen en la parte moderna de la ciudad permite sacar a la luz buena parte de los cementerios fenicio-púnicos y romanos pero no aporta información destacable sobre la ubicación y características de

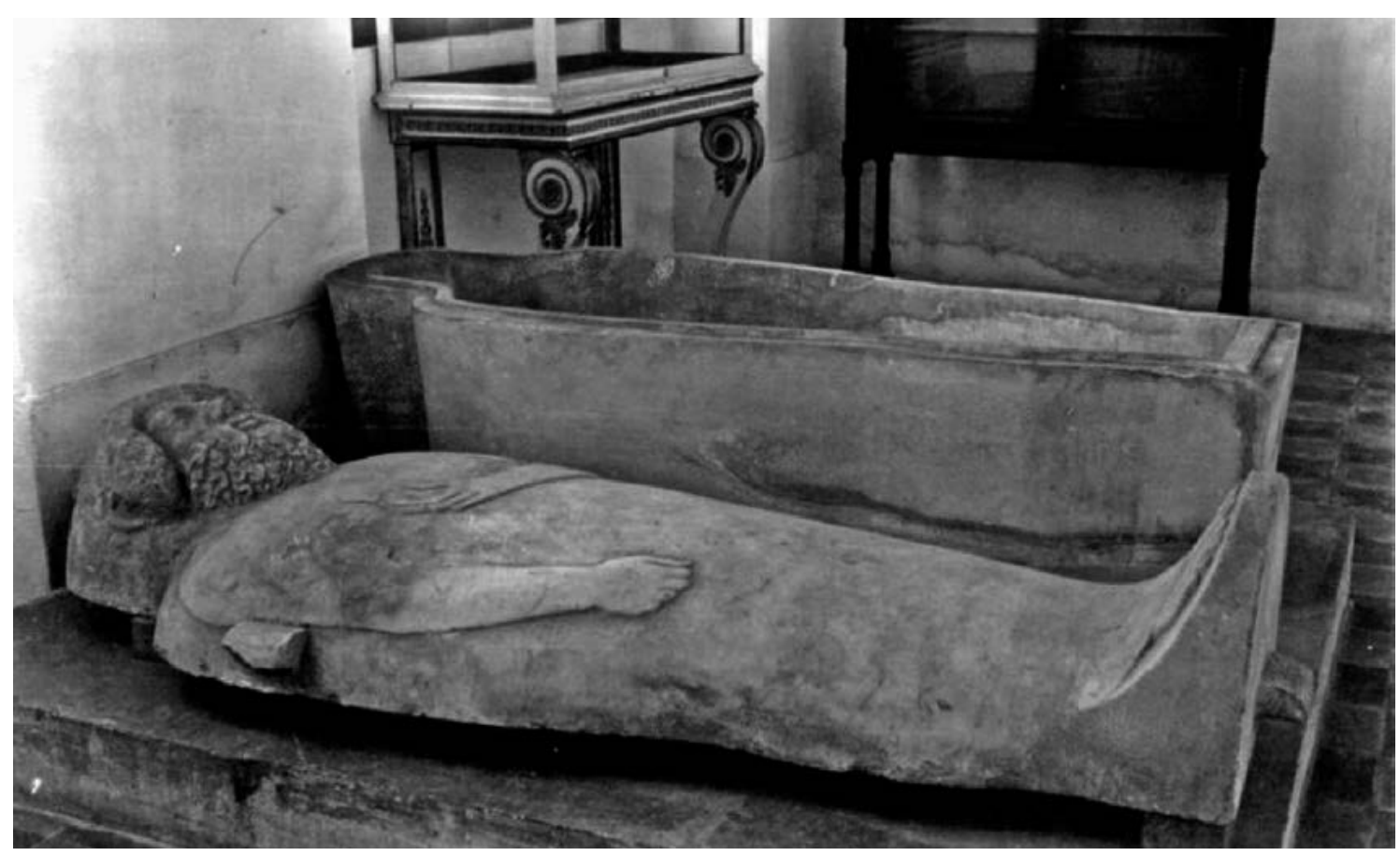

Figura 5. Imagen del sarcófago fenicio masculino descubierto en 1887 en las antiguas dependencias del Museo Arqueológico (fotografía Museo de Cádiz). 


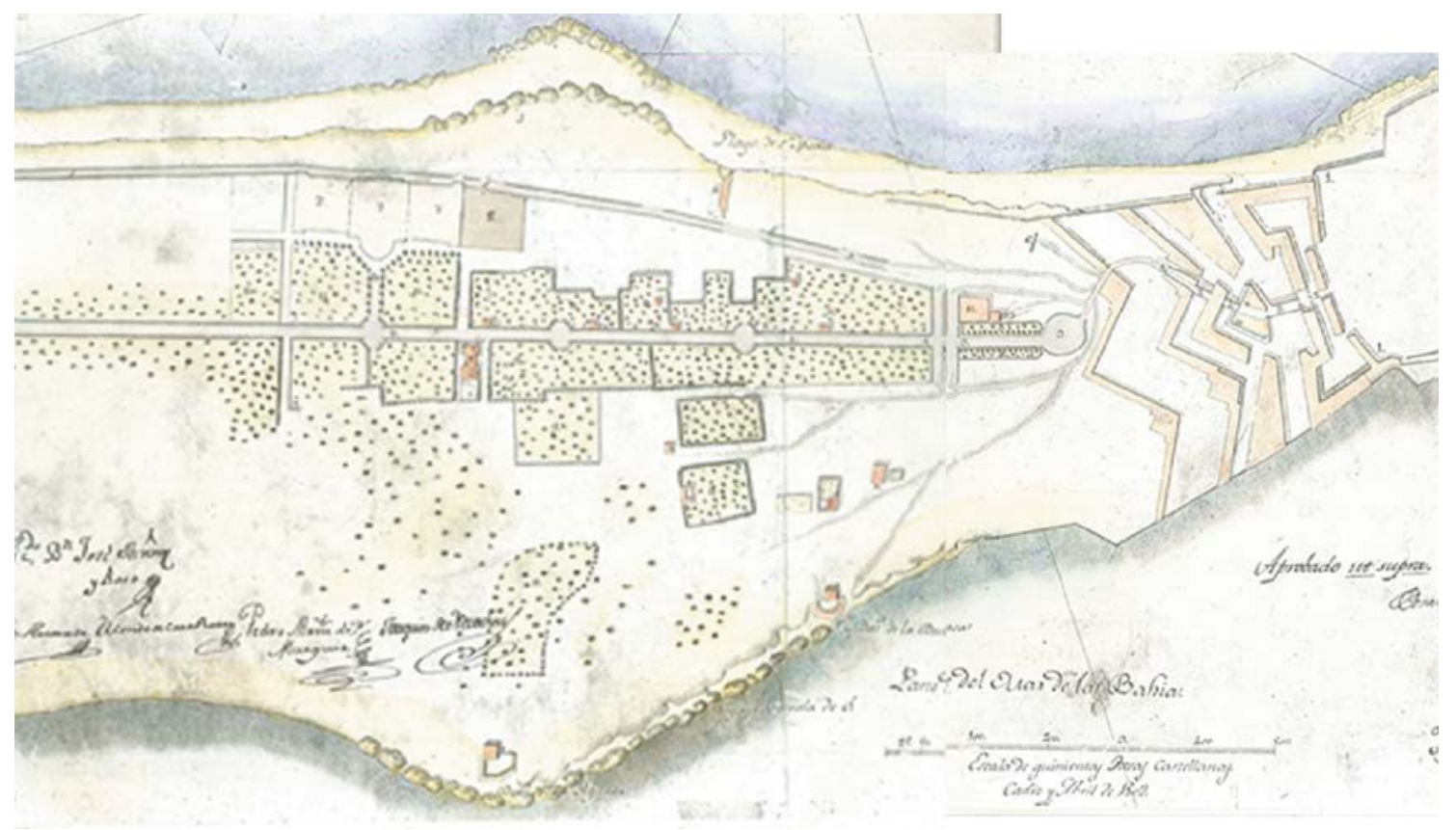

Figura 6. Plano firmado en 1802 por el arquitecto Torcuato J. Benjumeda con ocasión de su proyecto de cementerio en Extramuros, tras la epidemia de fiebre amarilla de 1800, en el que se aprecia el parcelario de extramuros formado por huertas a ambos lados del camino central de entrada a la ciudad y el estado inicial de la zona de la Punta de la Vaca y su batería, antes de los desmontes para el ferrocarril de mediados del s. XIX (cortesía de Juan Ramón Ramírez Delgado).

la antigua ciudad ${ }^{4}$ que, según las noticias clásicas y la tradición, se sitúa al norte, intramuros de la ciudad moderna. La razón principal de esta elección debe buscarse en que la zona extramuros es en esos momentos el área de expansión natural de la ciudad, caracterizada por un poblamiento disperso compuesto por fincas de recreos y huertos a ambos lados del camino que recorre el istmo que une la ciudad de Cádiz con la vecina población de San Fernando, y algunos barrios constituidos por casitas bajas alrededor de iglesias y del cementerio (San Severiano y San José). Completan el paisaje diversas instalaciones industriales y militares, como la fábrica de torpedos y algunas bodegas junto a la Segunda Aguada, llamada así porque era donde se facilitaba el descanso de los animales durante el transporte y trasiego; una zona que, en aquellos momentos, se situaba en plena línea de costa (Fig. 6). Se trata también de un momento de intensa actividad constructiva, que modifica de manera sustancial el paisaje anterior mediante desmontes y rellenos para acondicionar el terreno a los

\footnotetext{
4 "Pero, si bien es verdad, como afirman los anteriores arqueólogos que niegan la fundación de Cádiz en 1100, que no tenemos en Cádiz hallazgos arqueológicos que se correspondan con la fecha tradicional de su fundación, también es cierto que en el suelo de Cádiz no se han hecho excavaciones arqueológicas de ninguna clase, por medio de las cuales se hubiera podido llegar a la aclaración de este problema" (Jiménez Cisneros 1971: 40).
}

nuevos servicios (el tendido del ferrocarril moderno, la construcción de los nuevos astilleros Vea Murgía, etc.). En el curso de los trabajos de desmontes para la construcción de la Exposición Marítima Nacional de 1887, es cuando aparece el ya mencionado sarcófago masculino en la llamada Punta de la Vaca (Fig. 7).

Por el contrario, la ciudad intramuros se muestra como un espacio de reducidas dimensiones, rodeada por el mar, intensamente habitada y construida, con una ocupación histórica sin solución de continuidad desde la Antigüedad, cuya única posibilidad de expansión, además de en altura, es el citado istmo. Por tanto, los escasos hallazgos arqueológicos, nunca planificados, proceden de algunos solares de dimensiones medias que se reurbanizan: caso del Teatro Falla, el centro comercial donde se ubicaron los antiguos almacenes "Simago" y el edificio de la Central Teléfonica, entre otros. Si en el primero los hallazgos son de posible datación romana y funcionalidad industrial (Ramírez Delgado 1982: 123-124), el limo aparecido en la cimentación del edifico de los almacenes "Simago" fue uno de los puntales sobre los que se gestó la hipótesis de la existencia del canal que en época antigua atravesaba la ciudad (Ponce 2000), dividiendo el actual casco urbano y dando valor al testimonio de los escritores antiguos en su descripción del archipiélago original, formado, al menos, por dos islas habitadas. 


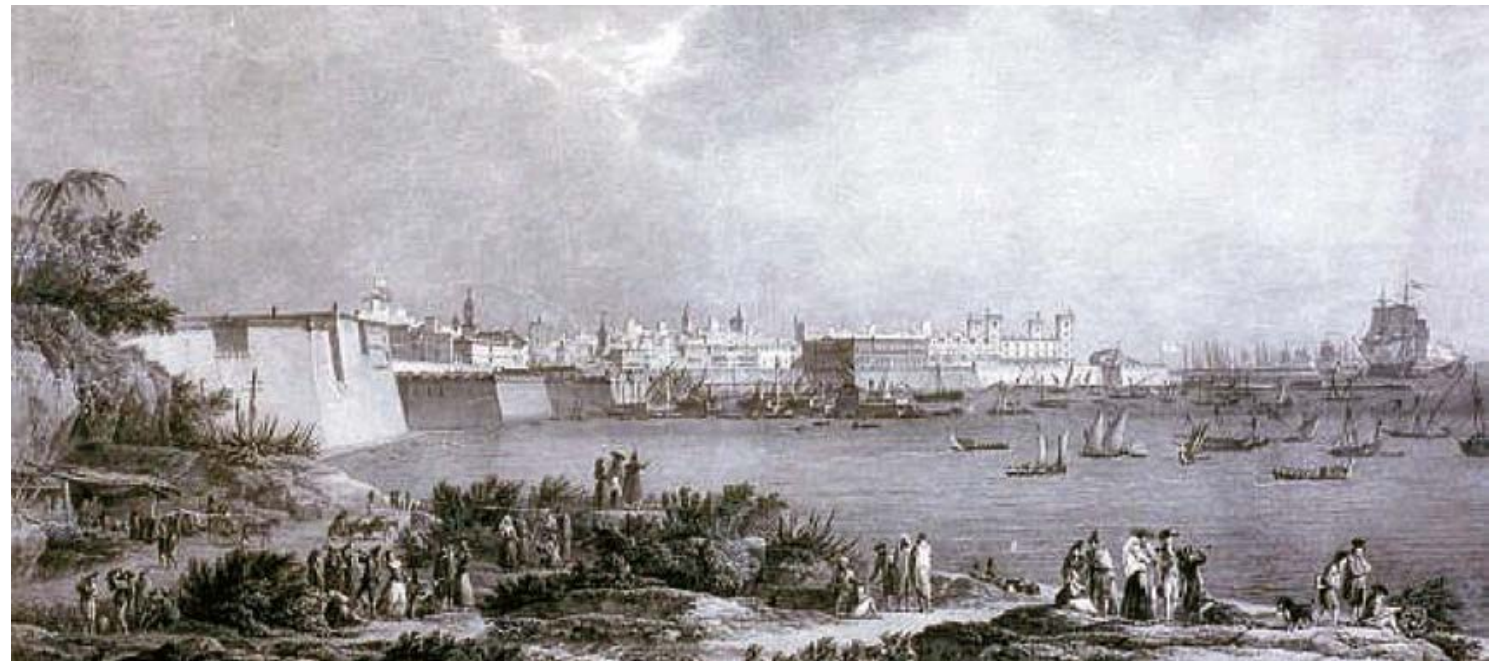

Figura 7. Vista del puerto de Cádiz desde la Punta de la Vaca. Grabado francés de Noel y Allix (1782. Museo Británico, Londres) (cortesía de Juan Ramón Ramírez Delgado).

Por último, la construcción de la Central Telefónica en 1928 sacó a la luz la famosa figurilla conservada en el MAN (Fig. 8), asociada a algunos restos constructivos que, aunque hechos desaparecer rápidamente, quedaron recogidos de forma documental (que no gráfica) por los eruditos de la época (Ramírez Delgado 1982: 102-104, n. 197). El hallazgo retoma con fuerza la primitiva hipótesis de la situación de la fundación fenicia en el casco histórico de la ciudad, que ante la ausencia de evidencias había sido desplazada, poco a poco, por la creencia que la antigua ciudad se debió situar en la zona más próxima al frente abierto al océano y, por tanto, destruida por el embate marino, por lo que sus ruinas se hallarían bajo las aguas.
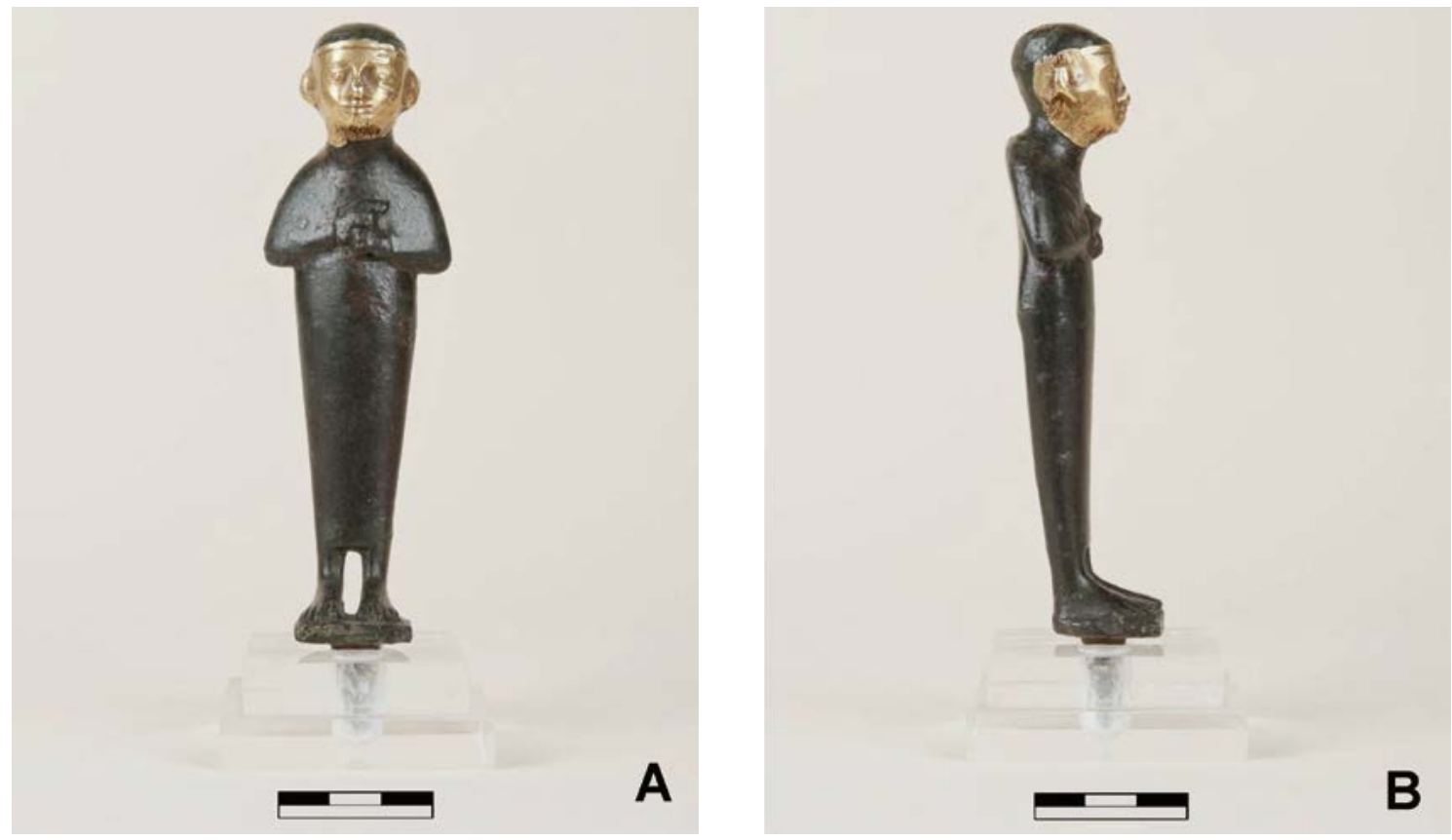

Figura 8. Figurilla de bronce con máscara de oro del dios Ptah hallado en 1928 en la Central Telefónica (c/ Ancha n 28, Cádiz) (fotografía Arantxa Boyero Lirón, MAN, No Inventario: 31920). 

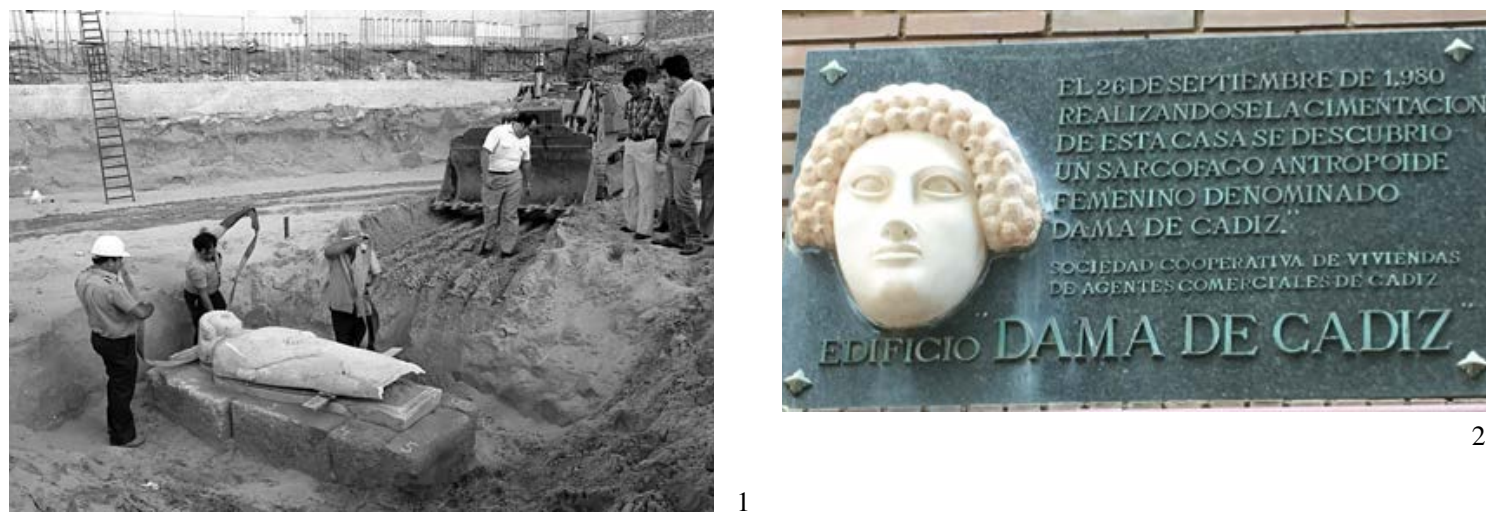

Figura 9. 1. Sarcófago antropoide femenino en el momento de su descubrimiento (fotografía M ${ }^{\mathrm{a}}$ Dolores López de la Orden, Museo de Cádiz). 2. Placa en la que se recuerda el hallazgo en el edificio actual sobre el solar del mismo (fotografía de la autora).

\section{EL "MODELO CLÁSICO" DE INTERPETACIÓN DE LA CIUDAD FENICIA}

En 1976 se publica en la prensa local una interesante propuesta firmada por Francisco Ponce Cordo$n^{n} s^{5}$, que propone la existencia de un paleocauce del río Guadalete -el conocido como "canal Bahía-Caleta", rebautizado recientemente como "Canal de Ponce" en honor a su descubridor- que dividiría en dos el actual casco histórico de la ciudad (Ponce 2000: 905). La hipótesis es rápidamente aceptada por otros investigadores (Juan Ramón Ramírez Delgado y Ramón Corzo en un primer momento y, años después, Oswaldo Arteaga al frente de un equipo multidisciplinar) que la completan y desarrollan, dando lugar a una nueva etapa historiográfica en la que se avanza de forma significativa tanto en la identificación de las islas citadas por las fuentes como en las propuestas concretas de localización del antiguo asentamiento fenicio. La existencia de una isla menor y una mayor adquieren así sentido. Mientras que el terreno situado al norte del canal se identifica con Erytheia, la menor de las islas, donde tendría lugar la fundación tiria, la que queda al sur, de mayor tamaño, se correspondería con la Kotinoussa citada por Timeo y Plinio, en cuyo extremo meridional se levanta el templo dedicado a Melqart. La configuración del antiguo archipiélago se completa con una tercera isla-Antípolis - identificada con la moderna Isla de León, donde se asienta la actual población de San Fernando. Si bien actualmente se pone en duda que el carácter insular de ésta perviviera en tiempos históricos (Frutos y Muñoz 2004a: 27), en los que el paisaje dominante, cambiante y en continua evolu-

\footnotetext{
${ }^{5}$ Suplemento del "Diario de Cádiz" del 12 de diciembre de
1976.
}

ción, sería el típicamente marismeño que favorecería la explotación de los recursos salineros y las comunicaciones entre las distintas zonas de la bahía. La identificación de las islas, no obstante, no está exenta de controversia. En este sentido, autores como Adolfo Domínguez Monedero han criticado la tendencia historiográfica a priorizar cuestiones como la identificación de las islas citadas en las fuentes y, sobre todo, sus nombres, que, como bien recuerda, son griegos y no fenicios, lo que podría enmascarar la realidad (Domínguez Monedero 2012: 155).

A partir de estos momentos se retoman los trabajos arqueológicos en la ciudad, impulsados por la aparición del segundo de los sarcófagos antropoides de tipo sidonio, en este caso femenino, en 1980 (Fig. 9). Las dos últimas décadas del s. XX y las primeras del XXI, una vez traspasadas las competencias en materia de cultura al gobierno autonómico andaluz, se han caracterizado por la normalización de la práctica arqueológica y por el control generalizado sobre las obras realizadas, lo que se ha traducido en la multiplicación de intervenciones arqueológicas. A su vez, toda esta actividad ha generado un ingente aporte documental y material, en su mayor parte aún por procesar (Niveau de Villedary 2010).

Como en etapas anteriores, en estos momentos la mayoría de los hallazgos arqueológicos se caracterizan por su naturaleza funeraria y suntuaria. Es precisamente esta ausencia de restos habitacionales lo que propició la proliferación de teorías y especulaciones, acerca tanto de la ubicación de la ciudad como del propio carácter urbano del asentamiento insular. En palabras de Ramírez Delgado: "Cádiz, la 'ciudad más antigua de Occidente', ha representado desde siempre un auténtico enigma para la ciencia arqueológica. Este halo de misterio que la envuelve se manifiesta, fundamentalmente, en dos cuestiones esenciales para nues- 


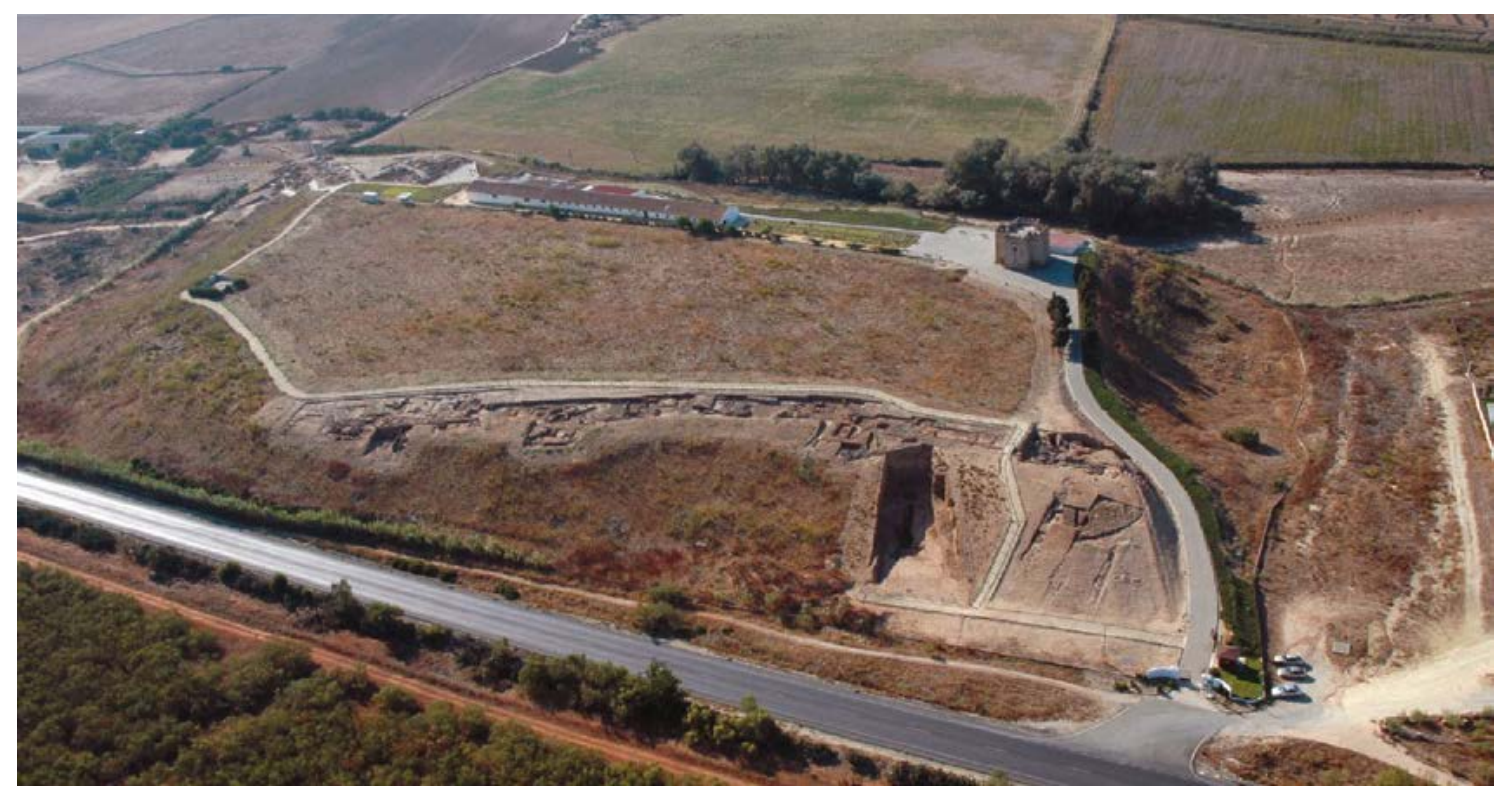

Figura 10. Vista área del yacimiento del Castillo de Doña Blanca (El Puerto de Santa Maria, Cádiz) (fotografía cortesía de José Ignacio Delgado Poullet).

tra historia más remota. En primer lugar, hay que considerar que seguimos sin poseer aún una confirmación directa y fehaciente de su propugnado origen trimilenario. En segundo lugar, es de destacar la falta casi absoluta de restos urbanos (excluidas, por tanto, las necrópolis) no solo de la etapa fenicio-púnica, sino también de la fase romana. Es este último problema, precisamente, el que se pretende analizar en este trabajo" (1982: 13).

Se trata de una etapa historiográfica definida, más que por la actividad arqueológica propiamente dicha, por la intensificación del eterno debate sobre la antigua ciudad en ámbitos académicos y científicos.

De un lado, y en sintonía con el panorama general de aquellos años (López Castro 1992), se discute sobre la cronología de la fundación de la colonia de Gadir, en el renovado intento de superar el desfase temporal entre los cómputos extraídos de las fuentes escritas y los hallazgos arqueológicos, en el contexto de lo que en aquellos momentos se definió como "precolonización".

Por otra parte, la ausencia de restos en el subsuelo gaditano quedaba compensada por los espectaculares hallazgos que en esos momentos tenían lugar en la orilla continental, en el yacimiento del Castillo de Doña Blanca (El Puerto de Santa María, Cádiz) (Fig. 10), que su excavador interpretaba, tras algunas dudas iniciales, como el reflejo en tierra firme de la ciudad fenicia extremo-occidental (Ruiz Mata y Pérez 1995). A pesar de la potente estratigrafía del sitio, con más de 9 metros de secuencia ocupacional ininterrumpida, los niveles fundacionales -como ocurría en otros yacimientos fenicios de la costa mediterránea peninsular (Prados 2007)- no permitían sostener fechas más antiguas para el establecimiento de las poblaciones orientales en el sitio que comienzos del s. VIII a. C. ${ }^{6}$

El descubrimiento de Doña Blanca reactiva la búsqueda de la ciudad insular y se retoman con fuerza las antiguas teorías sobre las posibles ubicaciones de la misma. Sin embargo, las particularidades que presenta Cádiz -comunes a la mayoría de las ciudades históricas-, con un casco urbano permanente e intensamente urbanizado y habitado, con edificios de pequeñas dimensiones y escasa cimentación que se sostienen por las medianeras de los colindantes etc., no facilitaban las intervenciones arqueológicas en los solares en caso de derribo de alguno. La protección a la que se sometió desde momentos tempranos el caserío gaditano ${ }^{7}$-salvo contadas excepciones-, reflejada en momentos más recientes en la redacción de los sucesivos PGOUs de la ciudad, tampoco ha contribuido a la excavación sistemática del subsuelo, salvo pequeños sondeos que, por motivos de seguridad, pocas veces han agotado la po-

\footnotetext{
${ }^{6}$ Fechas confirmadas por su excavador en diversos foros por dataciones radiocarbónicas nunca publicadas.

https://www.lavozdigital.es/cadiz/20100430/opinion/proteccion-caserio-neoclasico-gaditano-20100430.html; consultado el 2 de noviembre de 2018.
} 
tencia estratigráfica o alcanzado el suelo natural, sobre todo en las cotas topográficas más altas, que son, por ende, los sitios donde con más afán se ha buscado tradicionalmente la ciudad fenicia.

En este panorama, la discusión sobre la ubicación de la ciudad queda restringida al terreno de las probabilidades y no deja de ser tremendamente especulativa, como ya hemos señalado en otras ocasiones (Niveau de Villedary 2010 y e. p.).

Siguiendo a Juan Antonio Fierro, Juan Ramón Ramírez Delgado (1982: 63) se decanta por situar el lugar de asiento del Gadir fenicio-púnico en la isla de Erytheia, en el punto topográfico más alto de la ciudad actual (Fig. 11, 1), bajo la conocida como Torre Tavira, la torre vigía perteneciente a la Casa-Palacio de los Marqueses de Recaño, a unos $14 \mathrm{~m}$ sobre el actual nivel del mar (Ramírez Delgado1982: 85).

Ramón Corzo coincide con él en el reducido tamaño de la ciudad y también ubica en la isla menor la primitiva fundación tiria, que identifica con el Arx Gerions. Inicialmente, Corzo propone que en el punto más elevado, el correspondiente con la Torre Tavira, se levantara el templo a Astarté y no la ciudad; y sitúa el Kronion en la Catedral Vieja (Corzo 1980: 7) (Fig. 11, 2). La ciudad "pequeña" y "original" de Es- trabón la hace corresponder, a grandes rasgos, con el actual casco histórico de la ciudad de Cádiz, a excepción de los barrios de la Viña, Pópulo y Santa María que quedarían situados al otro lado del canal (Corzo 1980: 7). Junto a ella, la ciudad "nueva" construida por Balbo estaría ubicada en el llamado "Frente del Vendaval", desde los actuales barrios de Santa María y Pópulo hasta la isla de San Sebastián, y habría desaparecido por completo por el efecto erosivo del mar, que habría acabado con cualquier tipo de vestigio urbano (Corzo 1980). En un trabajo posterior propone una nueva ubicación para la ciudad fenicia arcaica: la plataforma rocosa existente entre el Castillo de Santa Catalina y la Punta del Nao, de la que tampoco quedarían rastros debido a la acción del mar (Corzo 1983: 10). No obstante, ni las intervenciones arqueológicas llevadas a cabo en el patio y en los accesos del mencionado castillo (Muñoz 1995-1996: 79), ni las prospecciones subacuáticas posteriores (HiguerasMilena y Sáez 2013) han aportado datos positivos en este sentido.

Poco después, José Luis Escacena retoma las ideas principales de estos autores y define el que hemos llamado "Modelo topográfico clásico de Gadir" (Niveau de Villedary e. p.) (Fig. 11, 3), que será el esque-

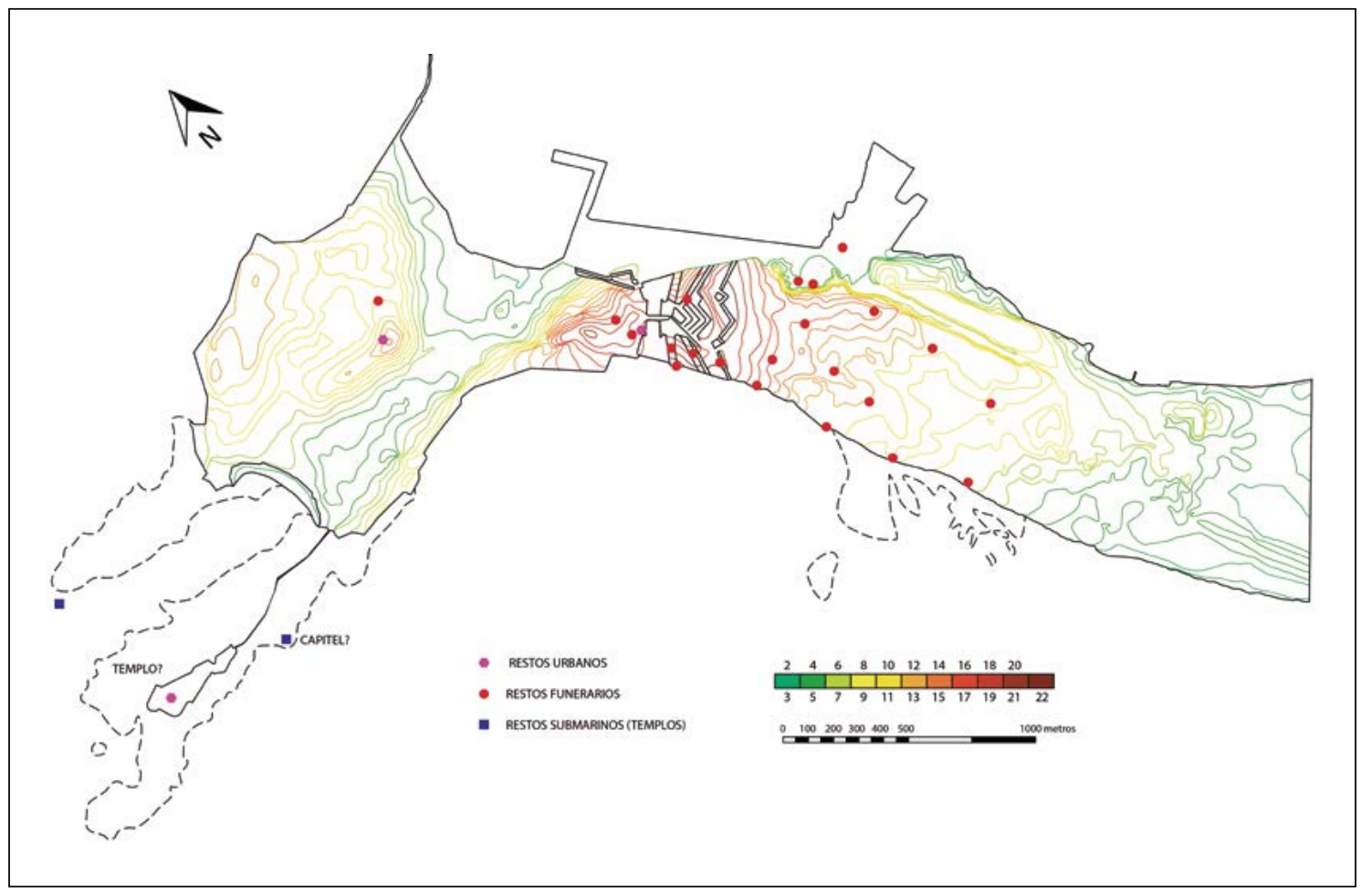

Figura 11. Paleotopografía de la ciudad de Cádiz y propuestas de ubicación de los asentamientos. 1. Ramírez Delgado (1982: fig. 1) (@ Pablo Sicre González, modificado a partir del original del autor). 


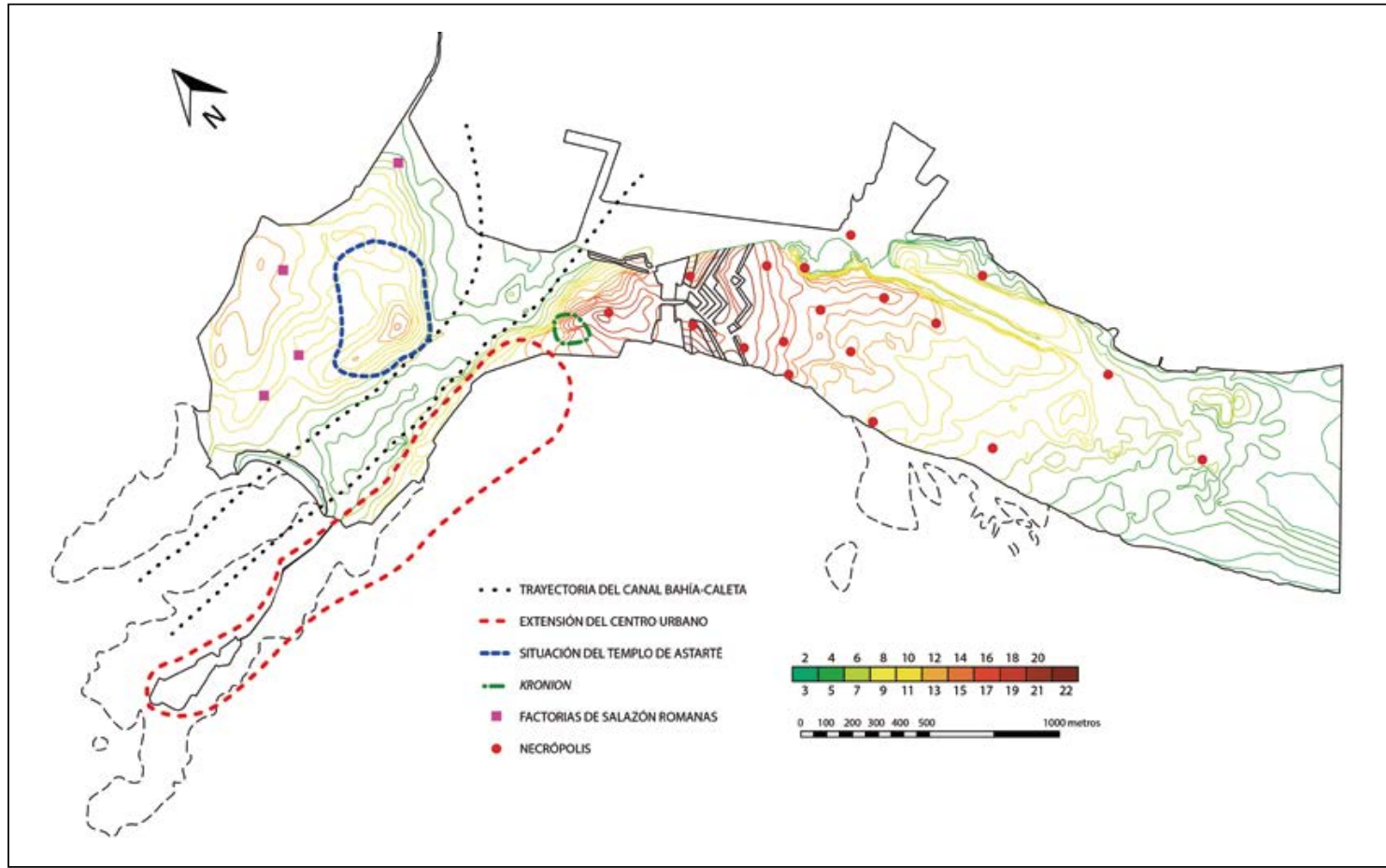

Figura 11. Paleotopografía de la ciudad de Cádiz y propuestas de ubicación de los asentamientos. 2. Corzo (1980: fig. 1) (@ Pablo Sicre González, modificado a partir del plano publicado por el autor).

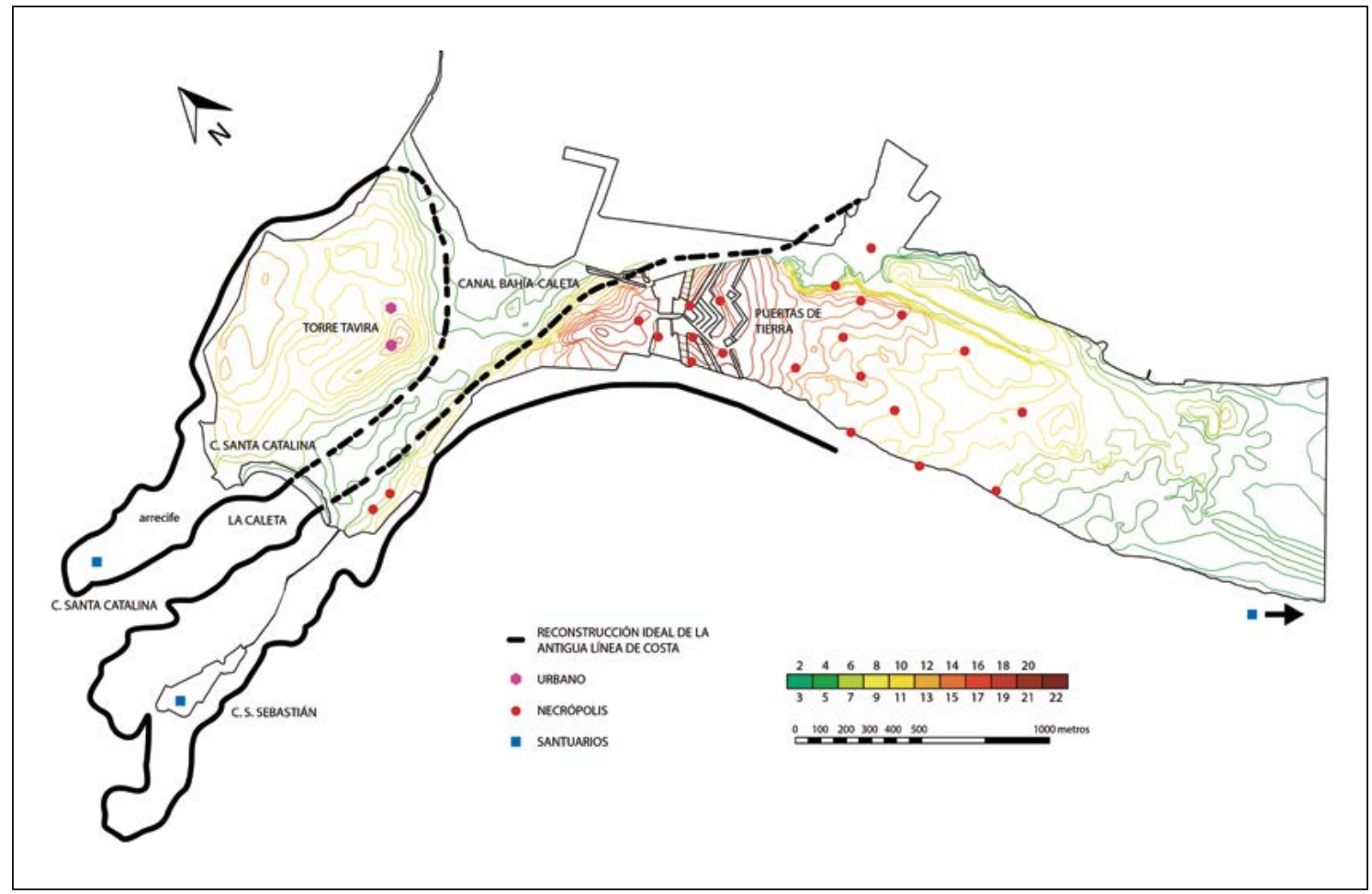

Figura 11. Paleotopografía de la ciudad de Cádiz y propuestas de ubicación de los asentamientos. 3. Escacena (1985: 42; fig. 2) (C Pablo Sicre González, modificado a partir del plano original). 


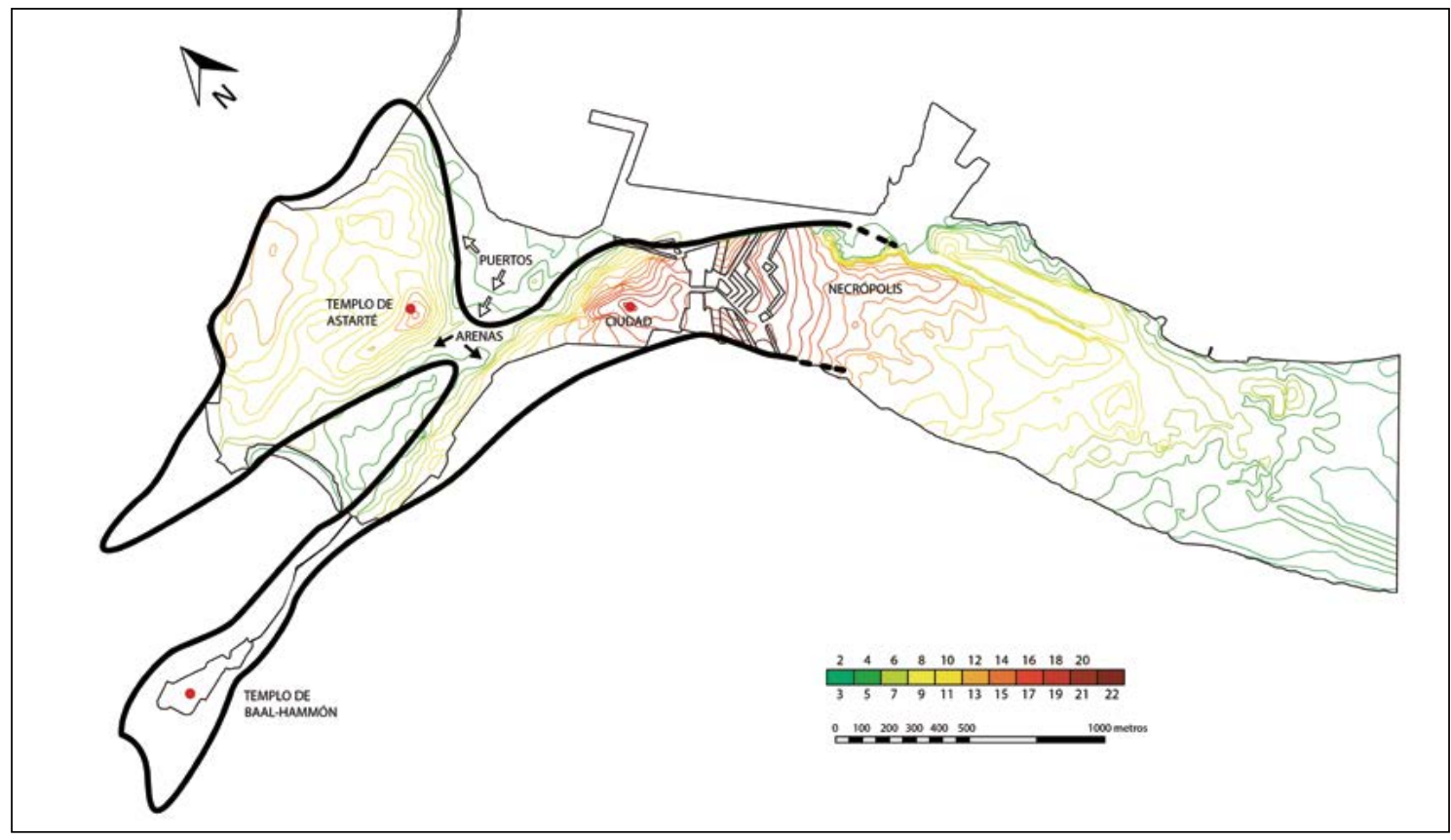

Figura 11. Paleotopografía de la ciudad de Cádiz y propuestas de ubicación de los asentamientos. 4. Álvarez (1992: 29) (C) Pablo Sicre González, modificado a partir del plano original publicado por el autor).

ma teórico que se fije y permanezca vigente en la investigación hasta finales del milenio. Escacena sitúa el núcleo urbano en la isla septentrional, en el altozano de la Torre Tavira (Escacena 1985: 44) y los templos en ambos extremos de la salida al océano del canal Bahía-Caleta: al norte, el santuario de Astarté, en el entorno del Castillo de Santa Catalina-Punta del Nao (Escacena 1985: 44-46) y en el opuesto el Kronion, ya en el extremo septentrional de Kotinoussa (Escacena 1985: 46). El templo de Melqart lo ubica en el extremo meridional de la isla mayor o Kotinoussa, en lo que hoy es el islote de Sancti Petri (Escacena 1985: 46-47), coincidiendo en este punto la mayor parte de los autores.

Disintiendo de la opinión generalizada que sintetiza el artículo de Escacena, Antonio Álvarez (1992), en otra vuelta de tuerca, intensifica el debate con una nueva interpretación de los datos textuales y de la información arqueológica más reciente en aquellos momentos y pasa a situar la antigua ciudad al otro lado del canal Bahía-Caleta, en el actual Barrio de Santa María, en terrenos de la isla meridional identificada con Kotinoussa (Fig. 11, 4). Según su razonamiento la isla pequeña estaría consagrada a Astarté (retomando la idea original de Corzo) y la ciudad habría que buscarla en el punto topográfico más alto de la otra isla, bajo la posterior ciudad romana (Álvarez 1992: 22).
En su hipótesis Álvarez se apoya en los posibles hallazgos de carácter fenicio que tuvieron lugar en torno a los años 90 en un solar de la c/ Concepción Arenal (Niveau de Villedary e. p.). No obstante, la asociación del conjunto cerámico con unas estructuras constructivas de tapial y posibles pavimentos muy mal conservados (Muñoz 1995-1996: 80, fig. 3) nunca ha quedado lo suficientemente clara. Tampoco la amplitud cronológica del elenco material $^{8}$ se ha considerado, por su parte, un argumento con el suficiente peso a la hora de situar en esta zona la primitiva fundación fenicia. A la problemática cronológica se une la espacial-funcional, toda vez que en el solar colindante salió a la luz un sector de la necrópolis de finales del s. VII - s. VI a. C. (Torres 2010: 56, n. 5). En cualquier caso, y fuera cual fuera su funcionalidad, el hallazgo de estructuras y materiales fenicios en esta zona no hace sino redundar en la consabida presencia fenicia desde tiempos arcaicos en la bahía y archipiélago gaditanos. A Álvarez corresponde el mérito de plantear por vez primera el cegamiento parcial del canal en tiempos prerromanos ${ }^{9}$, años antes de que lo hiciera Arteaga.

${ }^{8}$ Datados tipológicamente entre los siglos VII y sobre todo VI a. C., con alguna perduración de materiales más antiguos del s. VIII, caso de una posible ánfora fenicia oriental (Muñoz 1995-1996: 80, figs. 4 y 5).

9 La reconstrucción teórica sugerida por Antonio Álvarez nos parece más probable que la que años después planteara Oswaldo 


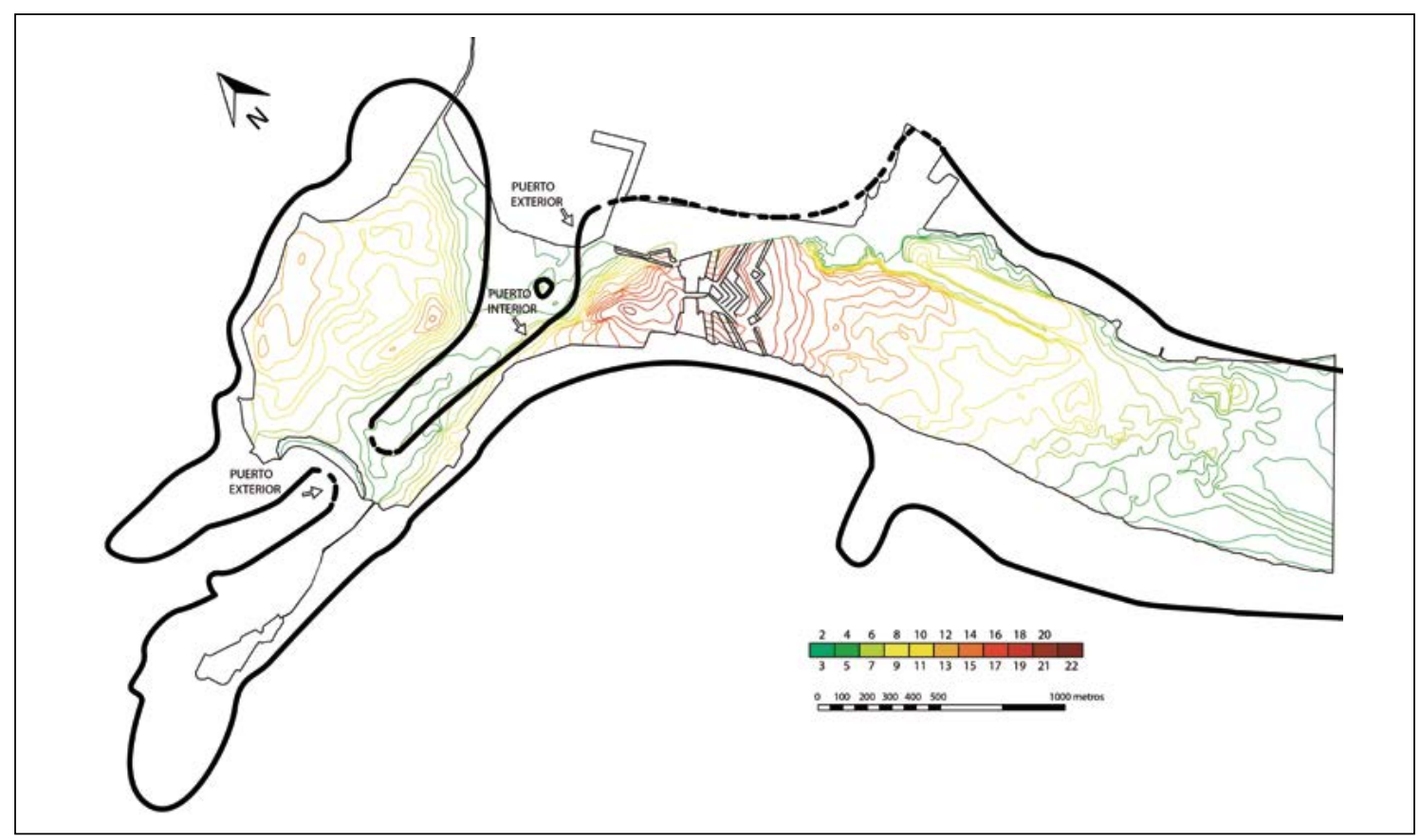

Figura 11. Paleotopografía de la ciudad de Cádiz y propuestas de ubicación de los asentamientos. 5. Arteaga y Roos (2002: 38; fig. 2) (C Pablo Sicre González, modificado a partir del original de los autores).

En esa misma década se formulan algunas propuestas que no han tenido igual eco en la investigación pero que conviene comentar siquiera brevemente, pues se anticipan al cambio de paradigma que trae el nuevo milenio. La primera de ellas viene de la mano de Antonio Caro. Este investigador no se muestra partidario de la existencia de un canal interior (Caro 1990-1991: 106-107) pero, sin embargo, y ahí radica la importancia del estudio, se adelanta al propio excavador del yacimiento portuense cuando propone que "Gadir (en referencia al enclave insular) y Doña Blanca deben ser considerados como un conjunto, como un solo núcleo" (Caro 1990-1991: 110). Aunque hace una diferenciación en la composición de la población: "orientales puros" en la Gadir insular y una población mixta formada por fenicios y tartesios en el enclave continental. Retomando esta idea, Juan Antonio Fierro (1995: 106-107) plantea

Arteaga tras la campaña de sondeos arqueogeológicos llevados a cabo por la Universidad de Bremen (vid. nota 14). Ambos autores reconstruyen un trazado ideal y esquemático, pero mientras que Arteaga sitúa el cegamiento en las proximidades de la salida del brazo de mar al océano (a la altura de la actual playa de La Caleta o sus proximidades), para Álvarez este tendría lugar en un punto central del recorrido, frente a la Torre Tavira; lo que resulta más probable si tenemos en cuenta tanto las circunstancias naturales (el régimen de mareas, vientos y otros) como los condicionantes antrópicos (el propio tráfico portuario, la evacuación de residuos urbanos e industriales, etc.). poco después que Gadir sea una "ciudad dual”: insular y continental.

A efectos de la reconstrucción del paisaje fenicio, el último hito destacado en estos momentos viene dado por las nuevas investigaciones geológicas llevadas a cabo en torno al trazado y naturaleza del canal Bahía-Caleta. Las perforaciones geoarqueológicas realizadas por un equipo de la Universidad de Bremen en el casco urbano de Cádiz permiten a Oswaldo Arteaga proponer la existencia de un puerto interior, que sitúa en la actual Plaza de la Catedral y que identifica con el puerto fenicio (Arteaga y Roos 2002: 26). En cuanto al trazado del canal plantea la existencia de distintos ramales delimitados por un pequeño "islote", que precipitaría la colmatación del curso de agua ya en época fenicia y que daría lugar a la existencia de dos puertos exteriores (Arteaga y Roos 2002: 28): uno situado en la Caleta, en mar abierto y otro en la bahía, donde se encuentra el muelle actual. Este último puerto, de funcionalidad comercial, quedaría conectado con el kothon o puerto interior identificado en la Plaza de la Catedral (Fig. 11, 5). No obstante, en la representación gráfica que acompaña al texto no queda claro el punto exacto por el que el canal se estrecha hasta terminar cegándose. En el croquis se observa que, en efecto, el pequeño islote situado cerca de la vertiente interior del canal (la que se abre a la bahía) pero, sin embargo, el defendido cierre se sitúa (sin que adivine- 
mos la razón) sobre la actual playa de La Caleta (Arteaga y Roos 2002: 38; fig. 2), zona abierta al mar aún en la actualidad, que continúa utilizándose como fondeadero de pequeñas embarcaciones de pesca. También resulta algo confusa la reconstrucción del trazado de las antiguas islas, pues no se ajusta a la paleogeografía de las mismas (sobre todo en la zona que limita con la bahía), habida cuenta que la primitiva línea de costa se retranquea al menos 300-375 metros de la actual, que es el resultado de aportes y rellenos realizados en pleno s. XX para ganar terreno al mar.

A pesar de estos aspectos problemáticos, la interpretación de Arteaga es rápidamente aceptada, sin demasiada crítica, por una amplia mayoría de investigadores, aunque no es compartida por todos. En este sentido hay que mencionar los estudios de un equipo de geólogos de la Universidad de Cádiz, en colaboración con miembros del Centro de Arqueología Subacuática que, a partir del análisis de estratigrafías sísmicas y secuenciales sobre perfiles sísmicos de alta resolución, siguen manteniendo que el canal BahíaCaleta constituye el resto fosilizado de un paleocauce del río Guadalete (Llave et alii 1999: 43) y no un estrecho formado entre dos islas por efectos de la inundación de los paleosuelos del paisaje plioceno-pleistoceno como proponían Arteaga y su equipo (Arteaga y Roos 2002: 27). El curso de agua, además, continuaría abierto y navegable a comienzos del primer milenio (Llave et alii 1999: 46; fig. 4), aunque empieza a estrecharse y a perder calado en su segunda mitad (Muñoz 1995-1996: 79). De la misma opinión es el equipo que ha excavado tanto el Teatro Cómico como la Casa del Obispo (Gener et alii 2012, 2014a y 2014b; Torres et alii 2014 y 2018; Zamora et alii 2010) que, aún sin haberse ocupado en concreto de este tema, reproducen la vía de agua abierta en la planimetría que acompaña las publicaciones sobre ambos yacimientos ${ }^{10}$; más recientemente, se han manifestado también en contra Lorenzo Abad y Ramón Corzo (2017: 91) y Juan Miguel Pajuelo ${ }^{11}$.

Por tanto, ambas interpretaciones (canal cegado en época fenicia o aún practicable durante estos momentos) incidirán directamente en las diferentes interpretaciones que se hagan a partir de estos momentos sobre el paisaje fenicio y la topografía de la antigua ciudad.

\footnotetext{
${ }^{10}$ De hecho, en la recreación de la evolución del paisaje que se proyecta en la musealización del Teatro Cómico (bajo el nombre genérico de «Yacimiento Gadir»), se representa el canal abierto y navegable hasta época romana (Vid. Niveau de Villedary 2018: 108; fig. 8).

${ }_{11}$ Manifiestamente a favor de la navegabilidad del canal en momentos prerromanos se muestra Juan Miguel Pajuelo en su estudio inédito: "El segundo puente romano de Cádiz" (2017). Agradecemos al autor la consulta del trabajo, así como sus comentarios y aclaraciones.
}

El paisaje insular no puede entenderse sin el hinterland continental (Botto 2014a). Desde un momento temprano se levantan en tierra firme, al menos, dos grandes asentamientos. El Castillo de Doña Blanca (El Puerto de Santa María, Cádiz), situado junto a la desembocadura del Guadalete, puede considerarse el gran establecimiento y puerto fenicio continental, siguiendo el modelo dual isla-costa de la ciudad de Tiro (Ruiz Mata 2016: 314), el esquema seguido en la mayor parte de las fundaciones fenicias a lo largo del Mediterráneo (Prados 2007). Se trata de un asentamiento de características urbanas, amurallado y con una arquitectura oriental desde su mismo origen a comienzos del s. VIII a. C. (Ruiz Mata 1999: 303-306). Más al sur, y quizás algo posterior en el tiempo (con los datos disponibles hasta el momento), se localiza el yacimiento del Cerro del Castillo, emplazado en la zona alta del casco urbano de la actual población de
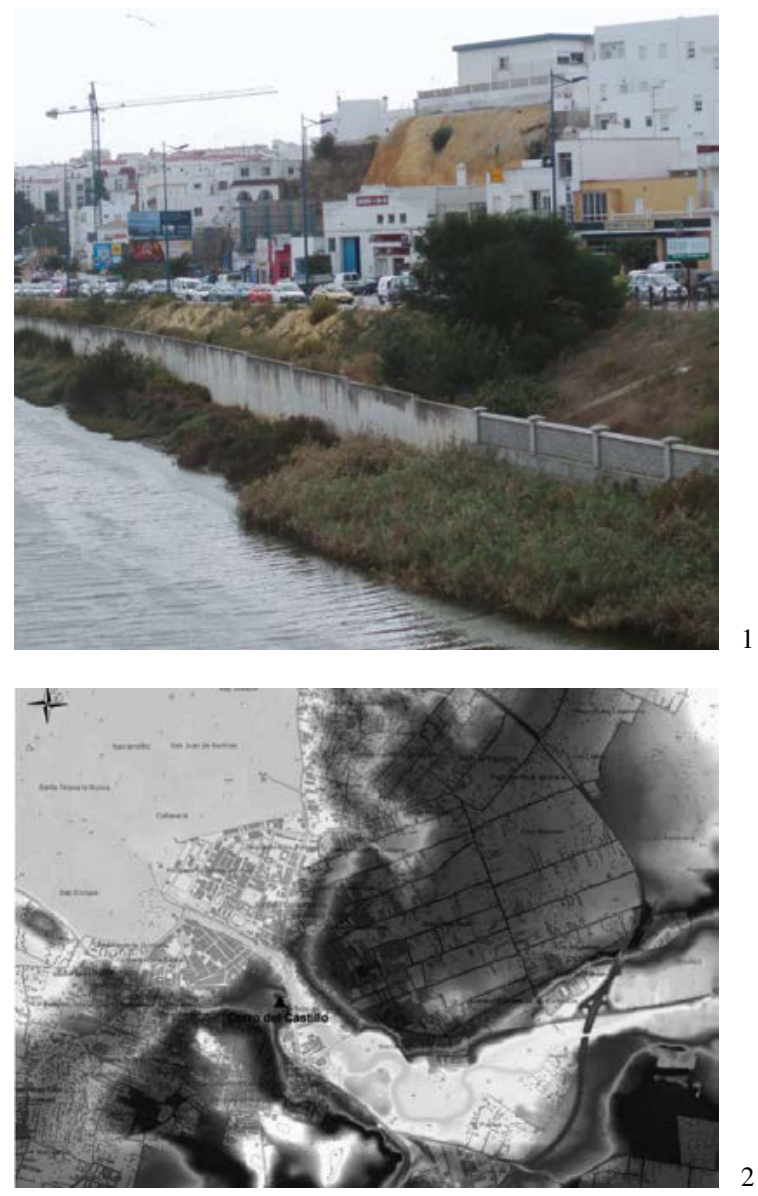

Figura 12. Yacimiento de el "Cerro del Castillo" (Chiclana de la Frontera, Cádiz). 1. Situación del Cerro del Castillo sobre el Río Iro (Bueno 2014: 226; fig. 2). 2. Modelo Digital del Terreno del Cerro del Castillo y su entorno (Bueno 2014: 227; fig. 3). 
Chiclana de la Frontera (Bueno 2014). El asentamiento, amurallado desde al menos el s. VII a. C., se sitúa en tierra firme, junto a la antigua desembocadura del río Iro y frente a la ubicación tradicional del templo de Melqart (Fig. 12). Una posición estratégica que permite controlar, de manera tanto efectiva como simbólica, el límite meridional del territorio de Gadir.

En cualquier caso, no hay que perder de vista que tanto el paisaje como el modelo de asentamiento son cambiantes y dinámicos y se muestran en continua transformación, por lo que en cualquier análisis que se acometa hay que tener en cuenta el factor tiempo y evitar una imagen fija (y, por tanto, sesgada y, en consecuencia, irreal) de lo que hubo de ser Gadir a lo largo de su historia.

\section{EL CAMBIO DE PARADIGMA Y LA CRÍTICA AL MODELO TRADICIONAL: EL "MODELO DE ASENTAMIENTO POLINUCLEAR O LA CIUDAD PLURAL"}

El descubrimiento y excavación del yacimiento del Castillo de Doña Blanca supuso el reconocimiento del rápido e intenso impacto que la llegada de los fenicios tuvo en la población local (Ruiz Mata y Pérez 1995: 126). El asentamiento se interpreta en un primer momento como un poblado indígena rápidamente aculturado (Ruiz Mata 1999: 310-311) para, a continuación, pasar a calificarse como un enclave mixto (que contaba con un "barrio fenicio") (Ruiz Mata 1999: 313, n. 28) y, finalmente, considerarse una ciudad fundada ex novo con características netamente orientales desde sus orígenes (Ruiz Mata y Pérez 1995).

A partir de entonces se integra plenamente dentro del discurso explicativo global del poblamiento fenicio de la bahía de Cádiz hasta que su excavador, en un artículo publicado a fines del milenio (Ruiz Mata 1999), propone una interesante hipótesis que abre una nueva etapa en la historia de la investigación sobre Gadir.

A partir de los precedentes -si bien tímidos- analizados en el punto anterior, Diego Ruiz Mata plantea abiertamente la posibilidad de que el núcleo fundacional fenicio no se hallara bajo la actual ciudad de Cádiz, sino al otro lado de la bahía, en el yacimiento del Castillo de Doña Blanca, situado en tierra firme junto a la antigua desembocadura del río Guadalete (Ruiz Mata 1999: 311); hipótesis que defiende por una serie de razones: el mejor posicionamiento del enclave continental frente al insular, la posibilidad del acceso rápido y fácil a los recursos naturales (agua y madera) y a las vías de comunicación, su posición de entrada natural al hinterland continental con las oportunidades de obtener mano de obra y las facilidades para la apertura de relaciones y mercados con la población autóctona, entre otras ventajas que no presentaba el enclave insular. Tesis en las que ha insistido su autor en trabajos posteriores (Ruiz Mata 2016 y 2018).

Dicho planteamiento, reproducido en el ámbito local por ciertos sectores de forma descontextualizada, levantó ríos de tinta y airadas réplicas (Muñoz 1999), recogidas incluso en la prensa local (Niveau de Villedary 2010: 653, n. 270), que no hicieron sino demostrar que la propuesta de Ruiz Mata no había sido entendida en el círculo científico más cercano. Como consecuencia de lo anterior tuvo lugar un "renacimiento" de las teorías tradicionales, forzadas al extremo ${ }^{12}$, a favor de la fundación fenicia insular (Muñoz 2004; Rodríguez 2008). Para ello se esgrimieron toda una serie de argumentos que probaban, según sus defensores (Muñoz 1998 y 2004), la antigüedad de la ocupación insular, muchos de ellos endebles ${ }^{13} \mathrm{y}$, en cualquier caso, sin fundamentos científicos irrefutables en aquellos momentos en los que apenas habían empezado a descubrirse niveles fenicios arcaicos bajo la ciudad de Cádiz. Un ejemplo ilustrativo de la precipitación con la que se asumieron hallazgos aún en curso es el entusiasmo

\footnotetext{
12 Valga como ejemplo las siguientes líneas extraídas de la Revista del Ateneo gaditano: "No cabe duda que la presencia fenicia en Occidente es un punto de inflexión decisivo en nuestra historia. Punto que tiene su reflejo, en nuestra ciudad, nada más y nada menos que por ser la principal y más antigua fundación de los fenicios de Tiro en la Península Ibérica. Esta circunstancia reflejada por la mayoría de los autores clásicos (Veleyo Patérculo, Estrabón, Mela, Plinio...) ha venido siendo admitida por la mayoría de los investigadores que se han dedicado a esta etapa histórica de nuestra ciudad, aún cuando hasta incluso la década de los años ochenta del siglo pasado, las huellas de esta presencia fenicia difícilmente remontaba los inicios del s. VI a.n.e., si bien conocíamos, aunque descontextualizados, diversos materiales hallados por azar [...] que venían a mostrar tímidamente ese abolengo y origen fenicio de nuestro territorio insular" (Muñoz 2004: 67). Las cursivas son nuestras.

13 En aquellos años los argumentos materiales "más sólidos" utilizados para apoyar la existencia de la ciudad arcaica lo constituían un conjunto de objetos de posible naturaleza funeraria, la mayor parte sin contextos ni cronologías claras (Muñoz 1998), cuya validez ha sido refutada con posterioridad (Torres 2010). Son, además, objetos de lujo, en muchos casos importaciones "exóticas" que, generalmente, suelen tener una larga vida y permanecer en uso varias generaciones, por lo que su amortización puede distar hasta varios siglos del momento en el que se fabrican (Niveau de Villedary e. p.). Entre estos elementos (Muñoz 1998; Torres 2010) se encuentran la estatuilla del dios Ptah que apareció en los cimientos del edificio de la Central Telefónica en 1928, un anillo signatario con inscripción fenicia hallado en la necrópolis de Puerta de Tierra, un oinocóe protoático conservado en el Museo de Copenhague -cuya procedencia gaditana es más que discutible-, una pyxis de tipología levantina hallada de forma casual en la Playa de Santa María del Mar y una serie de vasos de alabastro procedentes de contextos funerarios romanos, que se han interpretado como fruto del expolio de tumbas fenicias arcaicas aristocráticas, por comparación con las halladas en las necrópolis de Almuñécar, Trayamar, Chorreras, Lagos, Casa de la Viña o Abdera (López Castro 2006; Martín Ruiz 2017).
} 
desaforado que desataron algunos de los primeros descubrimientos realizados en el solar del antiguo Teatro Cómico, al anunciarse (vía conferencia de prensa) el hallazgo de parte de la muralla fenicia de la ciudad ${ }^{14}$ (Niveau de Villedary 2010: 623-624, n. 23), noticia que los propios arqueólogos responsables de la excavación se vieron obligados a desmentir el día después ${ }^{15}$.

En suma, se puede afirmar que en esos momentos ninguna de las dos posturas contaba con argumentos definitivos a la hora de zanjar la cuestión de la ubicación de la antigua fundación tiria. Desde las posiciones más tradicionales se seguía defendiendo a toda costa que la ciudad antigua se encontraba bajo la actual, apelando a razones históricas (continuidad nominal y topográfica) y a las (pocas) evidencias materiales disponibles por entonces, que se forzaban para hacerlas encajar en el esquema prefijado. Junto a estas, las nuevas teorías representadas por la postura de Diego Ruiz Mata, que ponía en duda el hasta entonces incuestionable axioma, fundamentaban su argumentación en la existencia de un asentamiento urbano amurallado con características orientales al otro lado de la bahía, frente a la ausencia de evidencias en territorio insular. Sin entrar en valorar la magnitud del registro continental, fuera de toda duda, hay que reconocer, no obstante, la debilidad de los argumentos ex silentio en relación al registro gaditano; y es que la ausencia de pruebas materiales objetivas conocidas no anula la existencia de estas, solo demuestra que por las causas que sean no se está en posesión de ellas (bien porque no existan o bien porque aún no hayan salido a la luz).

En cualquier caso, lejos del ámbito local más tradicional, la hipótesis del modelo de poblamiento polinuclear en torno a la bahía de Cádiz caló pronto entre los investigadores que la asumieron con el entusiasmo de quien ve por fin una puerta abierta a lo que

\footnotetext{
14 En la portada del Diario de Cádiz del 9 de mayo de 2002 se desmentía la noticia con este titular: "La muralla 'fenicia' de Cádiz es de origen romano". En las páginas interiores (p. 51) se aclaraba: "Historia de un hallazgo de envergadura que nunca existió" y se abogaba por la prudencia y el rigor científico contra las interpretaciones apresuradas de lo que resultó ser una cisterna romana. La expectación levantada por los trabajos que se estaban desarrollando en el solar del Teatro Cómico era tal que ese mismo día el desmentido ocupaba hasta el editorial del citado periódico (Apéndice II).

15 Ante el cruce de acusaciones de los responsables políticos (Apéndice III), al día siguiente eran los propios directores de la excavación los que aprovechaban la plataforma que les brindaba la prensa local para realizar, según palabras textuales, "una serie de aclaraciones con respecto a los hallazgos de época fenicia" (Tribuna Libre, Diario de Cádiz, 10 mayo 2002) y zanjar definitivamente la polémica desde el ámbito científico del que nunca debió salir. En muchas ocasiones, y este es un buen ejemplo, la precipitación (movida por el deseo y la pasión) no es buena consejera a la hora de hacer historia, menos si esta es pretendidamente científica.
}

durante siglos se había mostrado como un callejón sin salida. El nuevo modelo, frente a lo que en un primer momento se defendió en los círculos locales, no pretendía trasladar la fundación de la ciudad del territorio insular al continental, sino que proponía un nuevo patrón integral de ocupación del territorio más acorde tanto con la singularidad paleograográfica del entorno como con el modelo de asentamiento, explotación y relación con el mismo. Siguiendo su planteamiento, Diego Ruiz Mata (1999) considera que bajo el término Gadir quedan englobados todos los territorios, insulares y continentales, situados en torno a la bahía de Cádiz. Se trata de un patrón de asentamiento, polinuclear y funcionalmente disociado (con diferentes núcleos urbanos, centros religiosos, instalaciones industriales, necrópolis, etc.) que encuentra refrendo en la forma plural por la que los griegos denominan a la ciudad: Gadeira. Esta propuesta (con matices y variaciones) es aceptada en la actualidad por la gran mayoría de los investigadores (Sagona 2004: 254; Niveau de Villedary 2008 y 2018; Domínguez Monedero 2012; Botto 2014; Padilla 2014; Ruiz Mata 2016 y 2018; por último, Escacena 2018) y con ella se abre una nueva etapa en la historia de la investigación.

Es cierto que tras la localización del asentamiento primitivo bajo el solar de la ciudad de Cádiz en territorio insular (vid. infra), la hipótesis de Ruiz Mata no puede seguir defendiéndose punto por punto como fue formulada en su momento pero, aunque con matices y a tenor de los datos materiales y textuales, es factible seguir manteniendo la existencia de una ciudad polifuncional con distintos focos localizados en el entorno de la bahía de Cádiz, tanto en las islas como en tierra firme, con funciones diferenciadas (Ruiz Mata 1999, 2016 y 2018; Domínguez Monedero 2012 y, por último, Escacena 2018). Estaríamos ante un asentamiento polinuclear y multifuncional, desde un punto de vista tanto de la apropiación/ocupación del territorio como de la explotación de este y de las relaciones sociales que surgen en su seno y que se reflejarían no solo en los espacios habitacionales o productivos sino también en las áreas funerarias. Una ciudad, en suma y como define el propio Ruiz Mata, "plural” (2016: 315).

\section{Y POR FIN... ¿APARECIÓ GADIR? LA (RE) CONSTRUCCIÓN DE LA CIUDAD DESDE LOS DATOS OBJETIVOS}

Centrándonos exclusivamente en el territorio insular, las tentativas de reconstrucción de la secuencia histórica de Gadir desde una perspectiva arqueológica se sucedieron a partir de la intensificación de la actividad arqueológica en la ciudad (entre otros, Muñoz 
1995-1996; Muñoz y Perdigones 2000; Frutos y Muñoz 2004b; Rodríguez 2008). Estos primeros trabajos tenían en común la aceptación sin discusión (la mayor parte de las veces de forma no consciente) del modelo explicativo vigente en esos momentos -el que hemos llamado "Modelo topográfico clásico de Gadir", sintetizado por Escacena (1985)-, y se limitaban a encajar los nuevos datos en el esquema (pre)fijado, con el objeto de intentar verificar a toda costa la existencia de la antigua ciudad bajo la actual, incluso forzando las interpretaciones en este afán.

No es sino hasta el cambio de milenio cuando el descubrimiento, la excavación y la publicación de un importante número de contextos arcaicos han permitido esbozar el panorama de lo que hubo de ser el asentamiento primitivo de Gadir (o al menos parte de él) a partir de datos materiales objetivos y no desde el deseo o la intuición.

Coincidiendo con el cambio generalizado de paradigma gracias a la identificación en diversos puntos del Mediterráneo de una fase de colonización inicial más antigua que la admitida hasta ese momento (López Castro e. p.), también en estos últimos años la investigación sobre Gadir ha dado un giro de ciento ochenta grados al salir a la luz restos urbanos arcaicos de distinta naturaleza y entidad -pese a que en ningún caso alcanzan la antigüedad de este "primer horizonte colonial"- en diversos puntos de la ciudad (Botto 2014b; Niveau de Villedary 2018).

Pese a que estas intervenciones han sido ya reiteradamente presentadas por sus excavadores en diversos foros y publicaciones (Córdoba y Ruiz Mata 2005; Gener et alii 2012, 2014a y 2014b; Torres et alii 2014 y 2018; Zamora et alii 2010; Ruiz Mata et alii 2014), e incluso se han llevado a cabo varios intentos de síntesis sobre la morfología, topografía y funcionalidad de la antigua ciudad (Padilla 2014; Ruiz Mata 2016 y 2018; Niveau de Villedary 2018 y e. p.), creemos que es necesario hacer de nuevo, siquiera de forma somera, un recorrido por dichos hallazgos con el fin de integrarlos de forma crítica en el actual modelo explicativo de la ciudad arcaica de Gadir que, lejos de clarificarse con la esperada aparición de restos materiales, no ha hecho sino complicarse ante la disparidad de opiniones, en ocasiones divergentes, de los diferentes especialistas en torno a cuestiones clave como la antigüedad, la disposición, la morfología y, sobre todo, la funcionalidad de los restos aparecidos en territorio insular; lo que se materializa en el surgimiento de modelos explicativos muy diferentes, que trataremos en el siguiente epígrafe.

Retomando el hilo del discurso, en el punto anterior ya se hizo referencia a la existencia de restos de procedencia (y cronología) incierta, pero de naturale- za fundamentalmente funeraria, que en su día fueron esgrimidos para sostener la presencia de una necrópolis fenicia arcaica en Cádiz y así demostrar, de forma indirecta, la existencia de un poblamiento fenicio acorde con la información literaria clásica (Muñoz 1998). En cualquier caso, ni el carácter descontextualizado de los propios objetos, ni la interpretación forzada de los mismos contribuyeron a argumentar científicamente la existencia de la ciudad arcaica (Niveau de Villedary e. p.), que sin duda existió, como luego ha quedado demostrado, aunque nunca bajo esos presupuestos acientíficos.

Los primeros restos materiales no funerarios de filiación fenicia cierta de los que se tienen noticia aparecieron en contextos no bien definidos, sondeos de dimensiones reducidas o rellenos secundarios situados al sur de canal, en la antigua isla de Kotinoussa (c/ Paraguay, c/ Concepción Arenal, c/ Botica y Plaza de la Catedral) (Ruiz Mata 2016; Niveau de Villedary 2018 y e. p.). Se trata de conjuntos fechados de forma vaga en una amplia horquilla entre los ss. VIII al VI a. C., aunque en general y salvo perduraciones (como una posible ánfora oriental), la mayoría eran materiales occidentales de fechas más avanzadas, datados entre los siglos VII y VI, de acuerdo a la secuencia de Doña Blanca (Ruiz Mata y Pérez 1995), que no permitían una interpretación más allá que la de corroborar la presencia fenicia de forma continuada en las islas desde momentos tempranos.

Por su parte, en la isla de Erytheia los datos eran, si cabe, aún más vagos. Los resultados de los sondeos realizados en el no 13 de la c/ Marqués del Real Tesoro, en el punto más alto de la ciudad actual, donde se suponía que debía estar la fundación original, resultan incluso a día de hoy contradictorios. Los resultados tanto de un primer sondeo que alcanza prácticamente los -7 metros como de la posterior perforación (hasta casi -10) fueron negativos y solo aportaron niveles de arena de duna estéril (Lavado et alii 2000: 870). Sin embargo, y según se desprende de la lectura de la memoria de una segunda intervención llevada a cabo en el año 2000, bajo los pavimentos tardopúnicos documentados, entre las cotas -5.40 y -5.80 , la arena dunar se presentaba más suelta y amarillenta, de color castaño claro y con manchas de ceniza. En ese nivel el porcentaje de material cerámico aumentaba ostensiblemente y se documentaron ánforas, varios fragmentos de plato de barniz rojo, una boca de oinocóe con barniz rojo y diversos fragmentos de cerámica de cocina (Blanco 2002: 16). Dicho estrato ha sido relacionado con el periodo de transición Fenicio II/III del vecino solar del Teatro Cómico (Gener et alii 2014a: 14).

Tampoco los resultados de las intervenciones llevadas a cabo en el Teatro Andalucía resultaron con- 
cluyentes. En la publicación de la intervención se citaba la existencia de un "nivel fenicio de playa", que los excavadores fecharon en el s. VIII a. C. (Cobos et alii 1995-1996: 117). No existían estructuras constructivas, aunque se halló una fosa rellena de tierras arenoarcillosas y algunos restos materiales y orgánicos que se interpretaron como un vertedero de desechos y una serie de "áreas de consumo" con restos de ánforas 10.1.1.1 y 10.1.2.1 y platos fenicios de barniz rojo. Los restos más antiguos se fecharían en el s. VIII a. C.

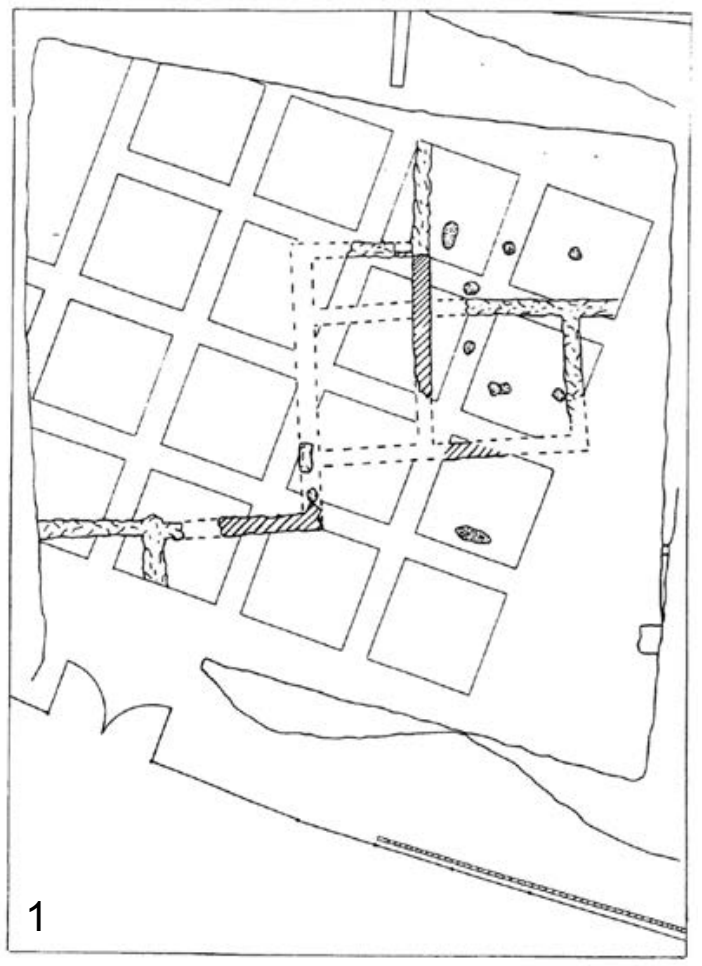

aunque otros son posteriores -VII a. C.-, siempre según sus editores (Lavado et alii 2000: 871).

Con estos precedentes, la situación real de la arqueología fenicia en Cádiz en los albores del milenio se movía en la fina línea que discurría entre la aparición de los primeros vestigios reales de ocupación fenicia en las islas y la urgencia devenida del deseo de la aparición de la ciudad antigua, largamente esperada. Esto provocó que, por una parte, los datos se sobredimensionaran y se tendieran a alzar algunas cronologías y, por otra, que dicha información se forzara hasta hacerla encajar en el modelo explicativo vigente definido en los años ochenta.

La realidad es que en esos momentos de la investigación los testimonios de ocupación arcaicos se limitaban a algunos puntos aislados, más evidentes (aunque también algo posteriores) en la isla de Kotinoussa: c/ Concepción Arenal, c/ Botica, c/ Paraguay (Muñoz 1995-1996; Niveau de Villedary e. p.), a los que seguía un dilatado hiato poblacional que no se rompería hasta el s. III a. C., cuando se advierte una fuerte reactivación del poblamiento en las islas que seguramente haya que relacionar con la llegada de los Bárquidas.

Las evidencias de estructuras habitacionales estables eran aún vagas y, como se ha apuntado, más tardías; aunque la aparición de restos de actividades antrópicas relacionadas con la explotación pesquera, el trasiego de mercancías y el consumo permitían sostener una ocupación que iría más allá de una mera frecuentación esporádica (Fig. 13).

Figura 13. 1. Restos constructivos fenicios de C/ Concepción Arenal (Lavado et alii 2000: 874; fig. 2). 2. Nivel de playa fenicia y progresiva colmatación del canal Bahía-Caleta documentado bajo el Teatro Andalucía (Cobos et alii 1995-96: 125; fig. 3).

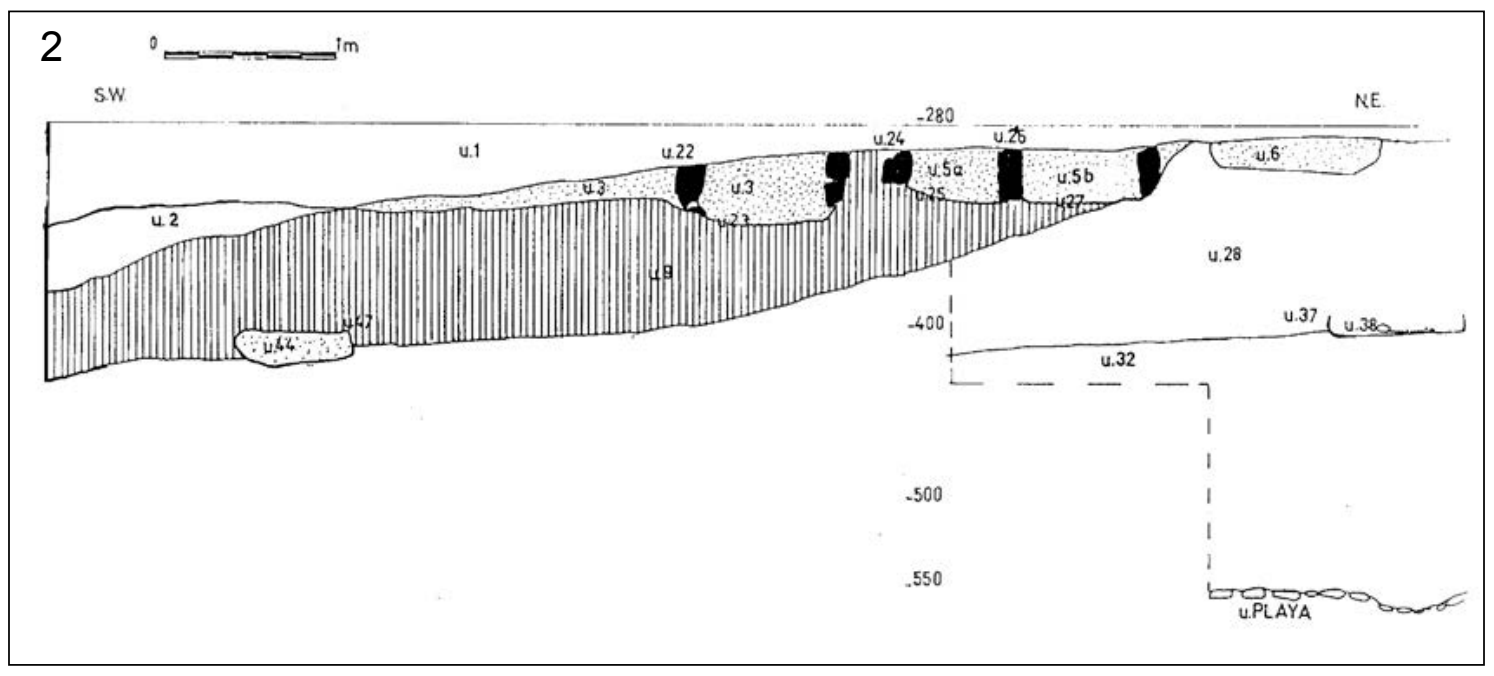




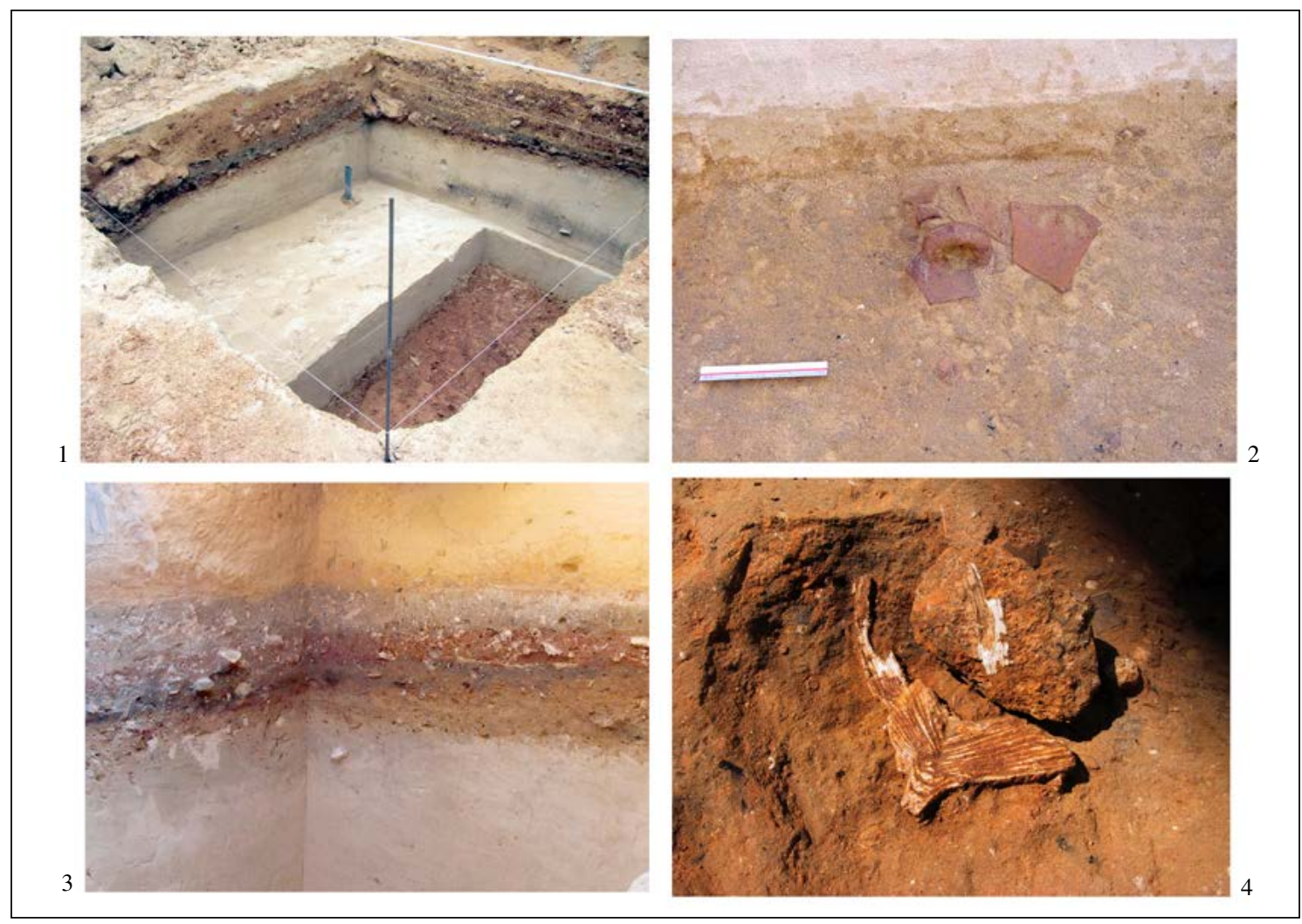

Figura 14. C/ Cánovas del Castillo n 38. 1. Vista general de la intervención. 2. Detalle de ánforas fenicias in situ. 3. Estratigrafía de la intervención con detalle de los diferentes suelos de ocupación entre estratos estériles de arena dunar de aportación eólica. 4. Restos de túnidos (fotografías Ignacio Córdoba Alonso).

No obstante, las principales novedades en cuanto a la constatación de la ocupación arcaica de las islas gaditanas han llegado en estos últimos quince años tras la excavación y publicación ${ }^{16}$ de los primeros contextos con horizontes monofásicos bien fechados en momentos arcaicos: c/ Cánovas del Castillo 38 (Córdoba y Ruiz Mata 2005) (Fig. 14) y c/ Ancha 29 (Ruiz Mata et alii 2014) (Fig. 15); las primeras secuencias crono-estratigráficas y las primeras evidencias de urbanismo: Casa del Obispo (Gener et alii 2014a) (Fig. 16) y, fundamentalmente, Teatro Cómico (Gener et alii 2012, 2014a y 2014b; Torres et alii 2014 y 2018; Zamora et alii 2010) (Fig. 17); y con la identificación y localización de la posible necrópolis arcaica en la c/ Hércules (Sáez y Belizón 2014) (Fig. 18). A toda esta información hay que sumar algunos datos novedosos sobre los templos,

${ }^{16}$ La publicación exhaustiva o, al menos, detallada y reciente de la mayor parte de los resultados de estas intervenciones nos exime de hacer aquí un análisis más profundo y remitimos al lector a la bibliografía generada por cada una de ellas y a las síntesis más recientes. como las últimas intervenciones en el Castillo de San Sebastián (Maya et alii 2014) (Fig. 19), Punta del Nao y alrededores de la Caleta (Sáez e Higueras-Milena 2016) que, aunque posteriores cronológicamente, abren interesantes perspectivas a la hora de confirmar la morfología del establecimiento fenicio fundado en el solar de la actual ciudad de Cádiz por los fenicios en momentos tempranos y contribuyen al mejor conocimiento y definición de la ciudad arcaica de Gadir. En este sentido, hay que traer a colación los recientes trabajos llevados a cabo en el sector más occidental de la isla de Erytheia, en el Colegio Mayor Universitario, en los que se han localizado materiales cerámicos del s. VII a. C. en el interior de un pozo (Sáez et alii 2019) (Fig. 20), un contexto similar al excavado en c/ Ancha, aunque posterior en el tiempo. Los citados hallazgos contribuyen a sostener la extensión de la ocupación fenicia hasta esta zona de la isla menor, posiblemente con una funcionalidad funeraria y/o ritual y su posible relación con el santuario de Astarté y sus dependencias anexas o con la actividad portuaria (y quizás industrial) del área en cuestión, situada junto a la playa de La Caleta. 


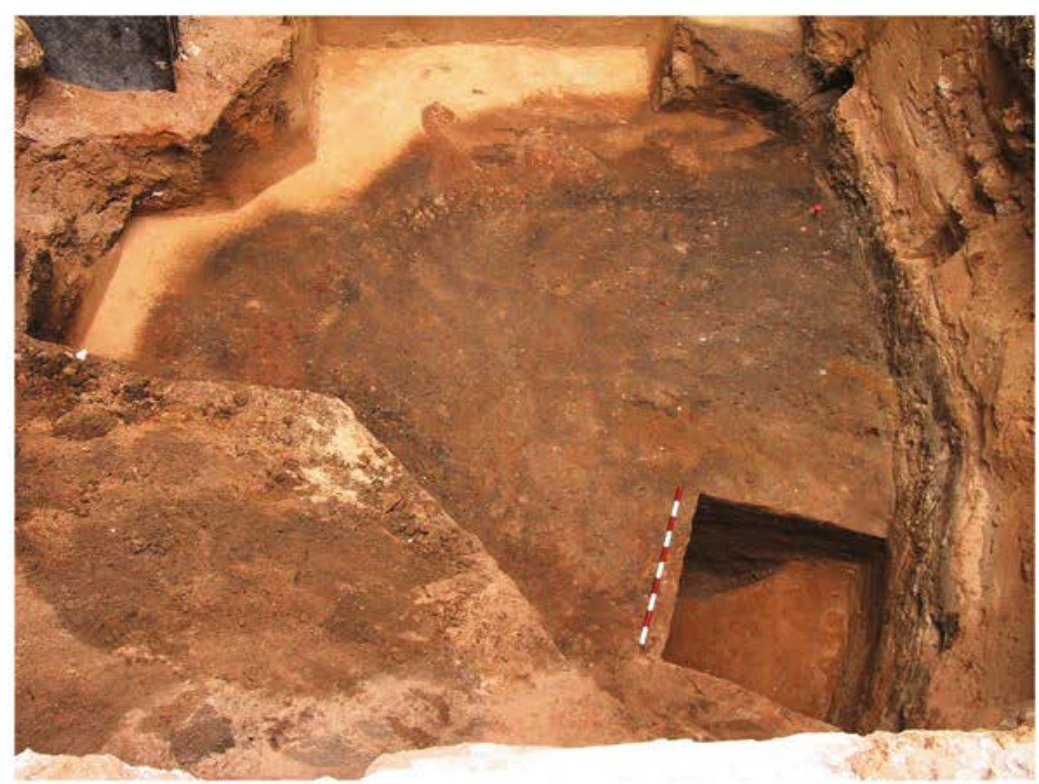

1

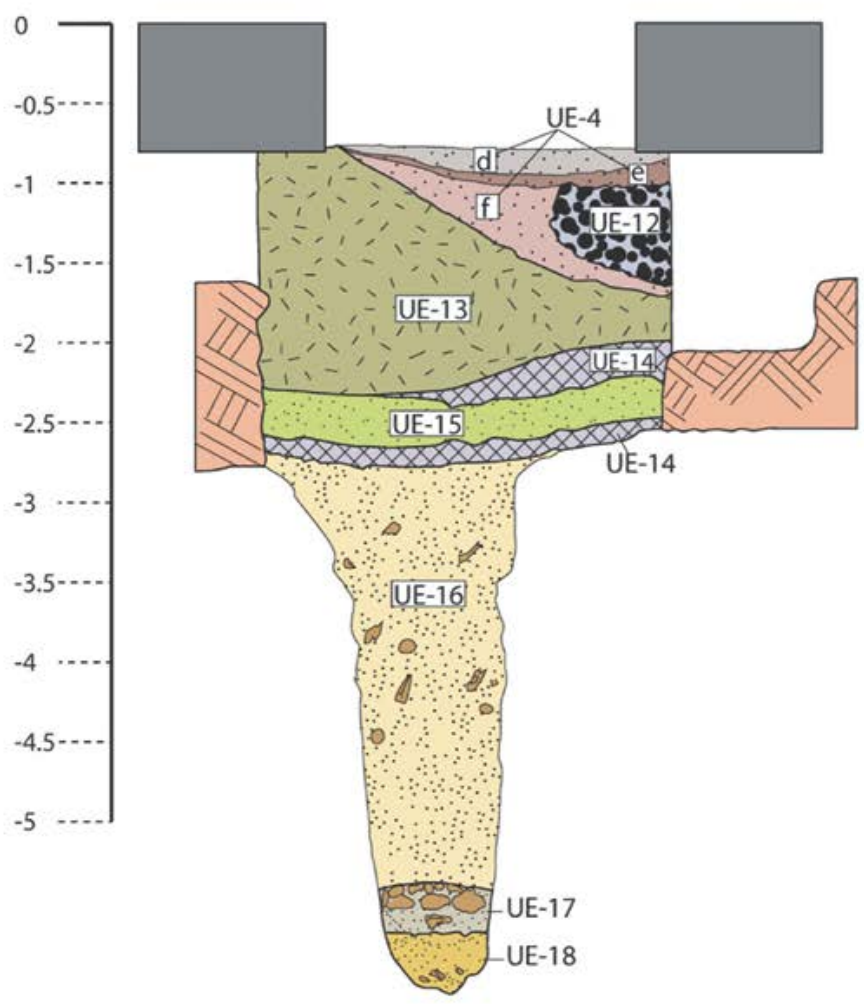

Figura 15. C/ Ancha n ${ }^{\circ} 29.1$. Vista general de la fosa con materiales fenicios y sondeo. Fotografía: Arqueogades S.L. 2. Sección del pozo excavado en la fosa (Ruiz Mata et alii 2014: 91; fig. 5b). 


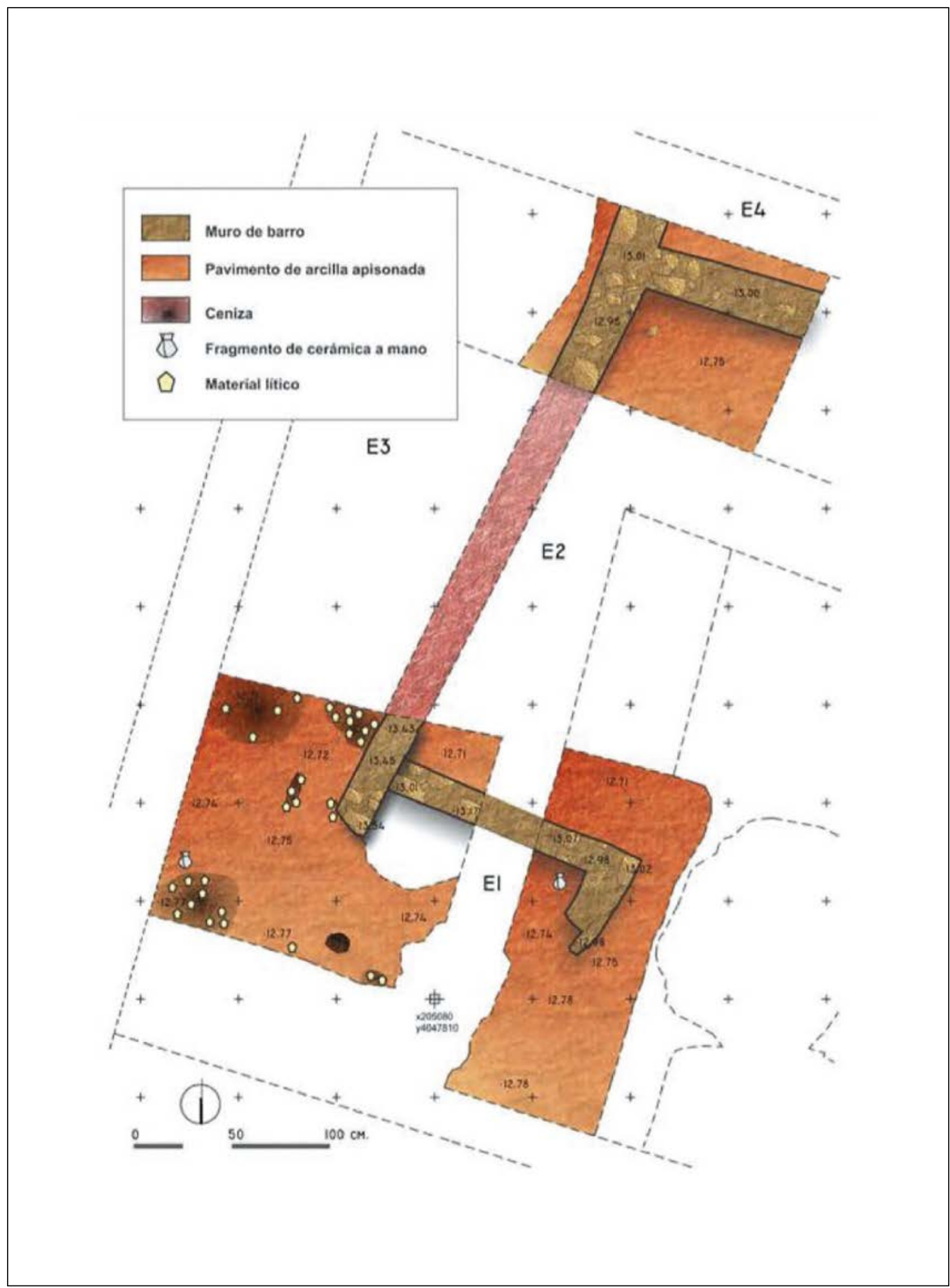

Figura 16. Planta de la Fase I de la Casa del Obispo (Gener et alii 2014b: 126; fig. 2a). 


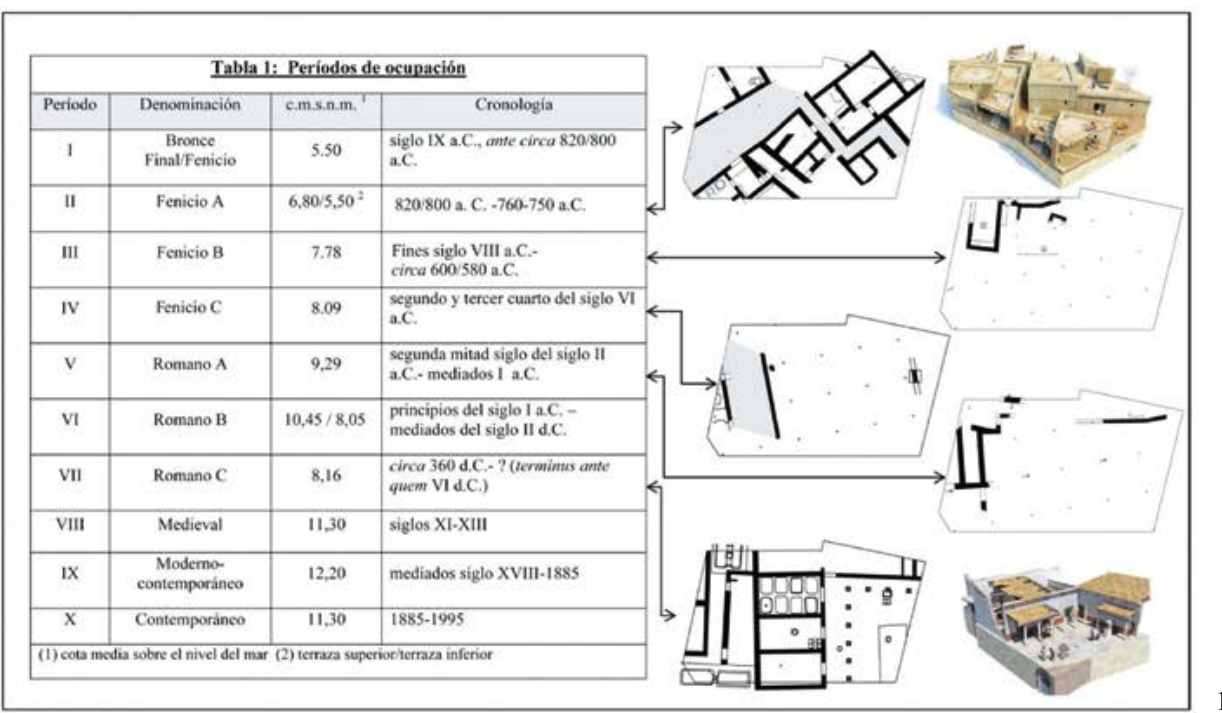
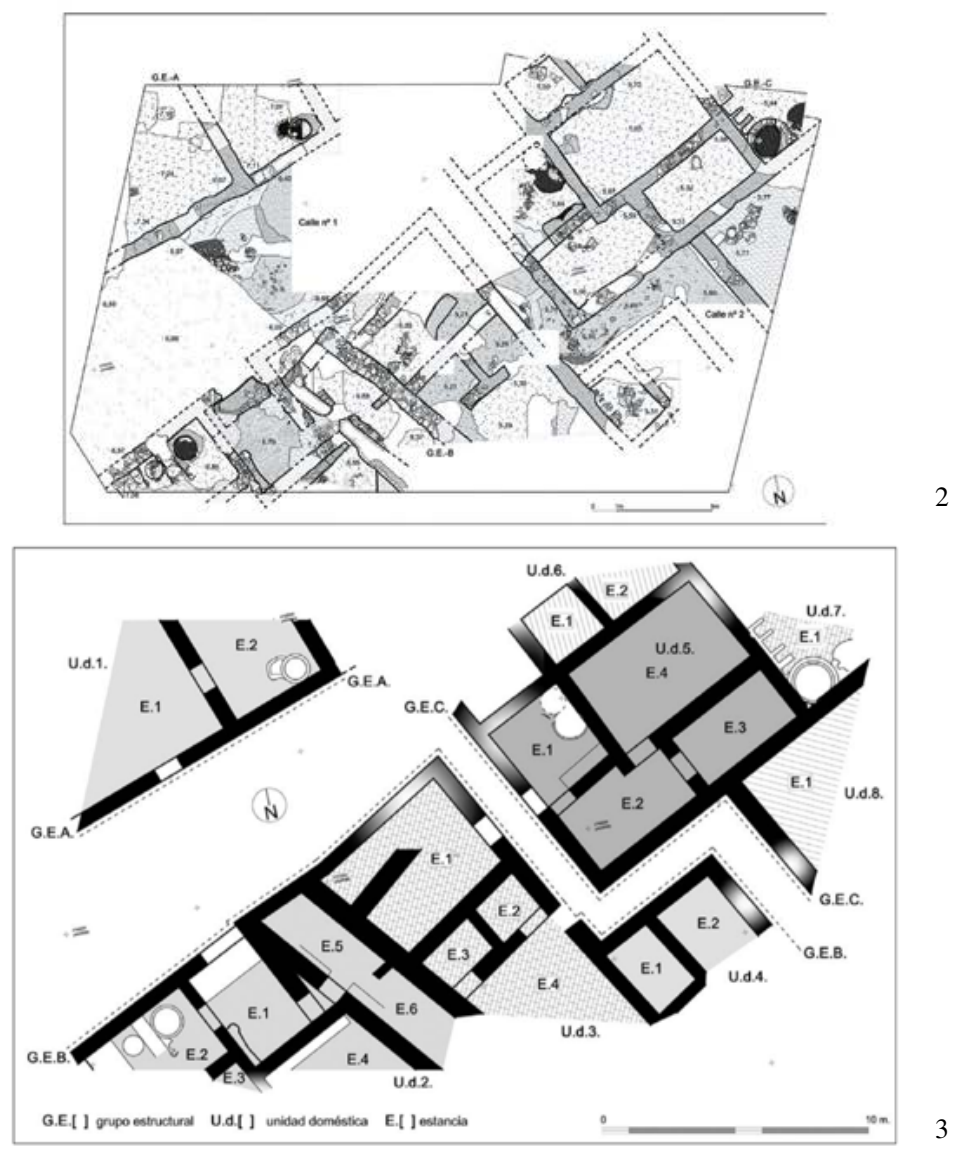

3

Figura 17. Teatro Cómico. 1. Periodos de ocupación (Gener et alii 2014a: 16; tab. 1). 2. Planimetría del Periodo II, Fenicio A (Gener et alii 2014a: 19; fig. 4). 3. Grupos estructurales y unidades domésticas del Periodo II, Fenicio A. (Gener et alii 2014a: 20; fig. 5). 


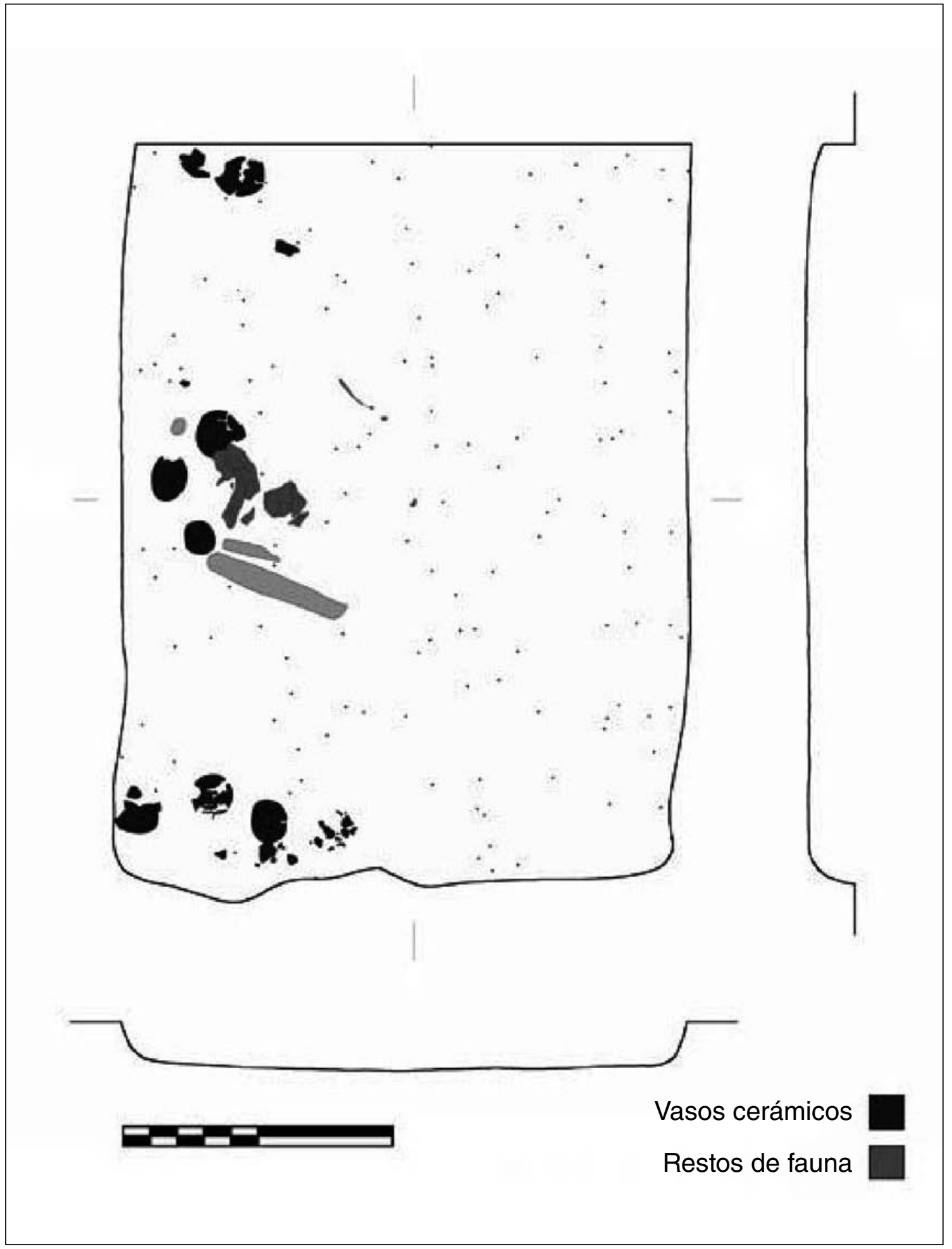

Figura 18. Planta y sección del posible enterramiento arcaico de la c/ Hércules 20 (Sáez y Belizón 2014: 186; fig. 4). 


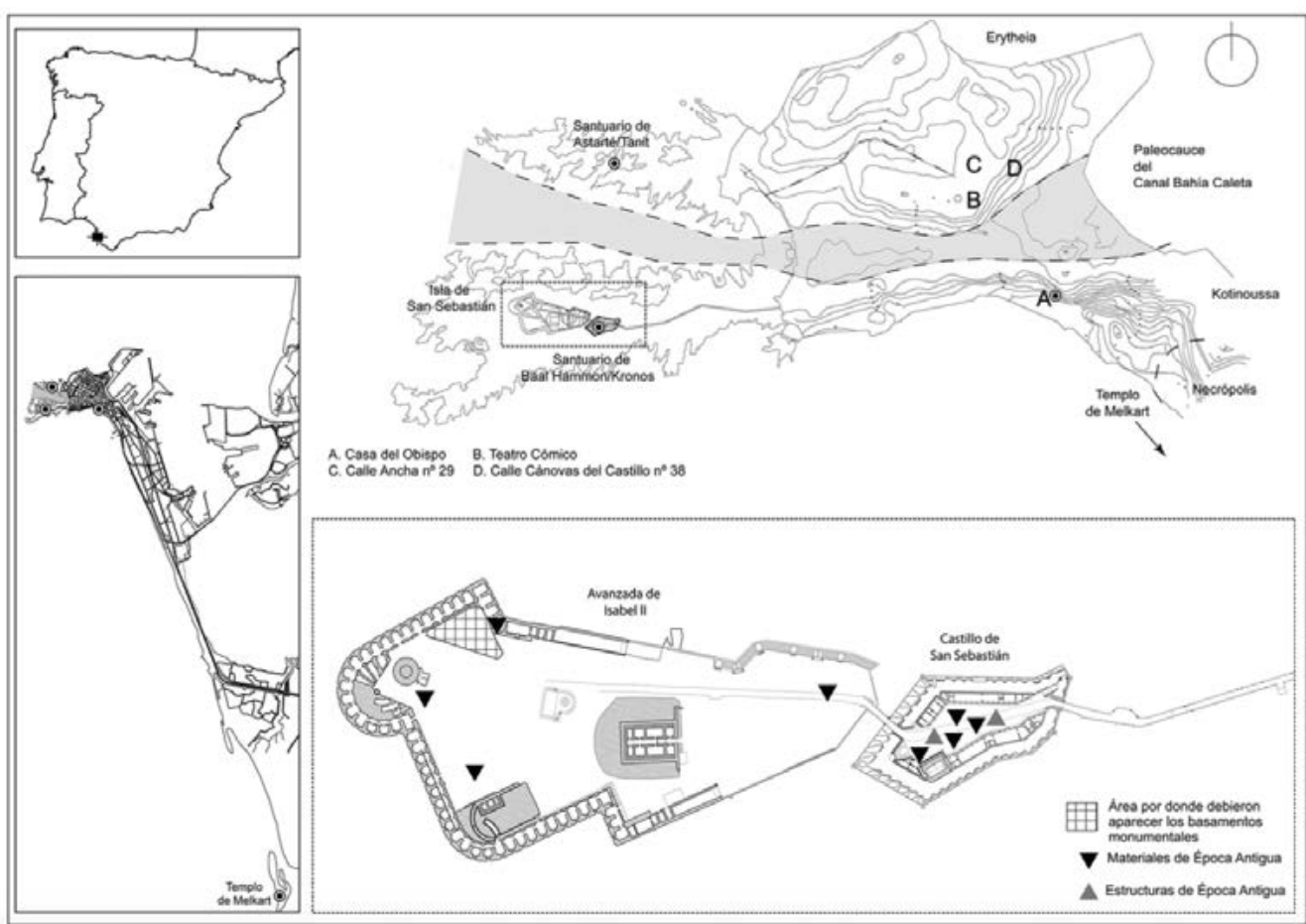

1
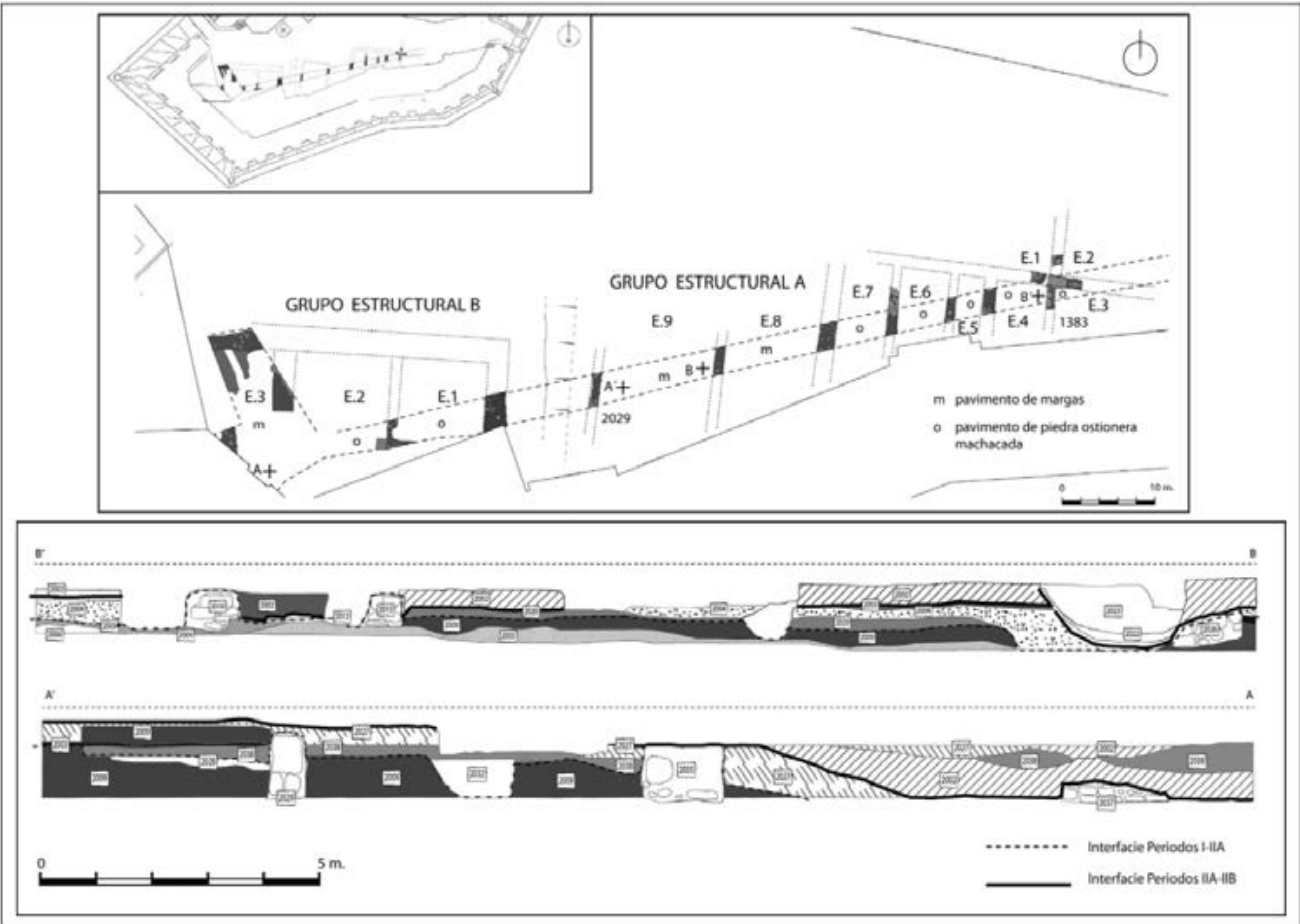

Figura 19. Intervenciones recientes (2009-2012) en el entorno del Castillo de San Sebastián, ubicación tradicional para el Templo de Baal-Hammón/Kronion. 1. Localización y topografía del Castillo de San Sebastián (Maya et alii 2014: 157; fig. 1). 2. Planta y perfiles del Periodo I / Fenicio (Maya et alii 2014: 165; fig. 6). 


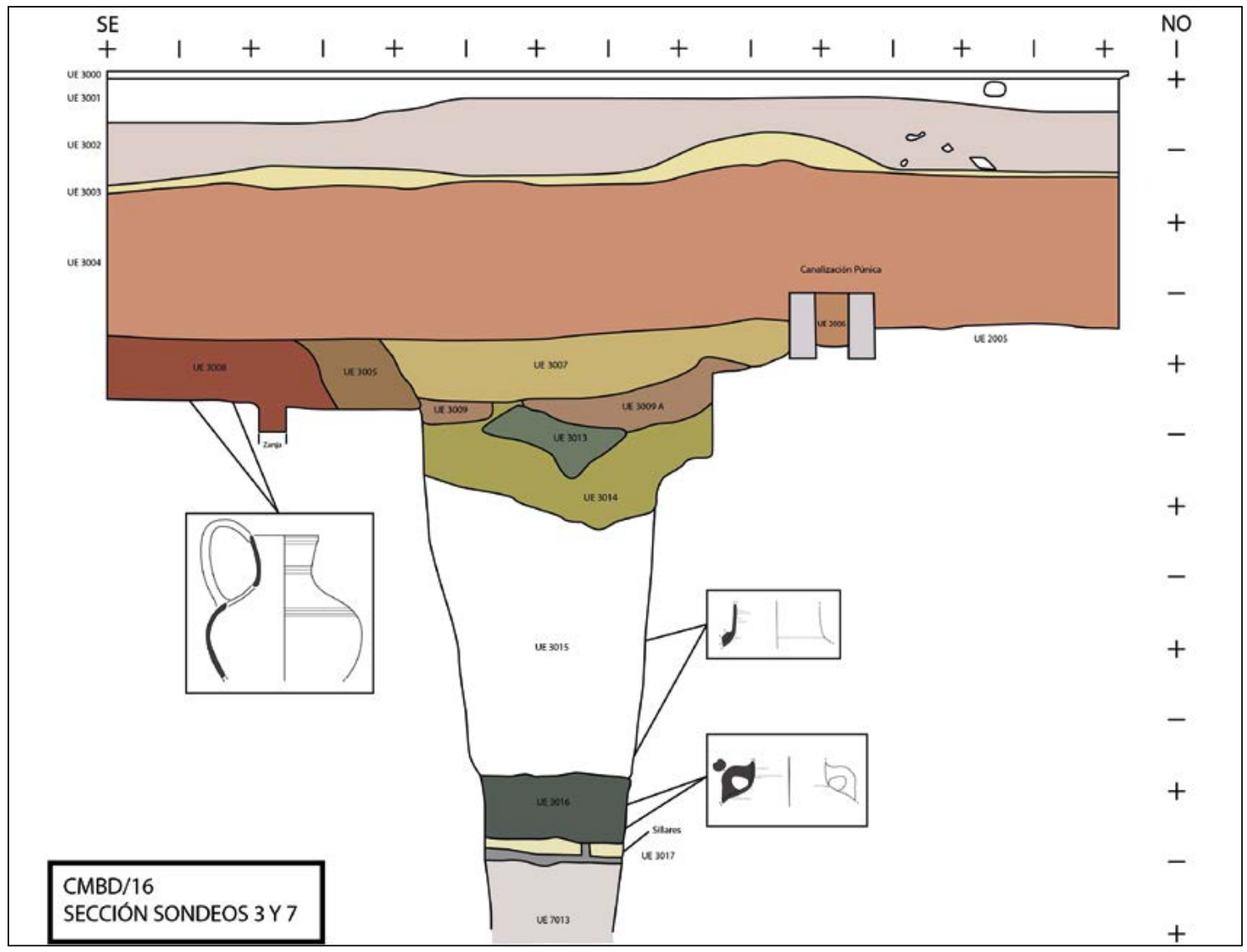

Figura 20. Sección y algunos de los materiales más significativos del pozo excavado en el Colegio Mayor Universitario (@Pablo Sicre González a partir de Sáez et alii 2019: 176, fig. 4).

\section{TENDENCIAS Y RETOS DE LA INVESTIGACIÓN EN LA ACTUALIDAD. ¿HACIA LA FORMULACIÓN DE UN NUEVO PARADIGMA?}

Gracias a todo este nuevo caudal de información ${ }^{17}$, en los últimos años han surgido distintas propuestas de reconstrucción de la morfología y funcionalidad de la antigua fundación tiria de Gadir, que si bien comparten algunos aspectos, difieren bastante en otros.

Uno de los modelos más completos en el que se analizan pormenorizadamente todos los elementos disponibles, tanto los hallazgos antiguos como las secuencias recientes, es el que desarrollamos hace un par de años (Niveau de Villedary e. p., un resumen de dicha propuesta en Niveau de Villedary 2018). Mediante la articulación de toda esta información hemos defendido la existencia, de acuerdo con sus excavado-

\footnotetext{
${ }_{17}$ Muchas de las intervenciones más recientes quedan recogidas en Botto 2014b.
}

res, de un foco urbano principal (con centro en el sector excavado en el Teatro Cómico), de funcionalidad habitativa, con un tamaño reducido, emplazado en la orilla norte del canal sobre cuya pendiente discurre suavemente, en un paisaje dunar mucho más plano que lo inicialmente supuesto ${ }^{18}$. Este centro principal, fundado hacia finales del s. IX-principios del s. VIII a. C., sufre hasta tres colapsos y sucesivas reconstrucciones hasta que se abandona definitivamente en el último tercio del s. VI a. C., sin que sepamos a ciencia cierta la ubicación de la ciudad a partir de ese momento ${ }^{19}$ (Niveau de Villedary 2014). El análisis de las vivien-

\footnotetext{
18 Uno de los argumentos sobre el que descansaba el "Modelo topográfico clásico" (\$ 3) era, precisamente, la altura sobre el nivel del mar de los puntos contemplados.

${ }^{19}$ Se han planteado varias posibilidades, siempre en el terreno de la hipótesis (Niveau de Villedary 2014), pues no han aparecido vestigios urbanos que puedan fecharse desde el siglo VI en adelante. La mayor parte de la información es de naturaleza funeraria, cultual o industrial. Un estado de la cuestión en Niveau de Villedary 2015.
} 
das, calles, equipamientos domésticos, evidencias de actividades y materiales documentados, además de confirmar el origen oriental de los restos urbanos, permiten defender con argumentos sólidos el carácter doméstico y privado de las estancias. Posiblemente se tratara, por el espacio disponible, de una ciudad de reducidas dimensiones (en torno a la hectárea propuesta por Domínguez Monedero 2012: 176), que se extendiera hacia el noroeste, donde es probable que se situara la acrópolis y/o los edificios públicos.

En cuanto a los límites meridionales, estos vendrían dados por el propio curso de agua (canal BahíaCaleta). Esta zona periurbana estaría relacionada con actividades de tipo portuario, carga y trasiego de mercancías y actividades pesqueras. Son espacios sin estructuras permanentes pero con restos de suelos y actividades antrópicas, fechadas en torno al s. VIII a. C. Ambas áreas, tanto la paleoplaya del Teatro Andalucía (al sur del asentamiento principal del Teatro Cómico) como el sector "pesquero" de Cánovas del Castillo (a poco más de $200 \mathrm{~m}$. al noreste), quedarían fuera de los límites físicos estrictos de la ciudad, aunque formarían parte de los "arrabales" periurbanos donde tendrían lugar diversas actividades económicas orientadas al aprovechamiento marino y al tráfico comercial y cuyos límites no serían fijos en el tiempo.

A unos 140 metros lineales al norte se localizan los espacios de c/ Ancha. El contexto descubierto en 1928, de dudosa adscripción por la falta de información fiable, es interpretado por algunos investigadores (Ruiz Mata 2016) como la gran tumba monumental de un personaje de alto rango (¿religioso?), en cuyo entorno se desarrollaría una intensa actividad de carácter ritual, cuyo exponente más explícito sería el gran foso relleno de materiales fenicios arcaicos hallado en el solar de enfrente (c/Ancha 29) (Ruiz Mata et alii 2014). En el interior de esta fosa se excava un pozo de funcionalidad desconocida, al que dicho investigador otorga un valor religioso-simbólico. Para Ruiz Mata esta misma asociación tumba heroizada de gran personaje-espacio subsidiario de culto en torno a este, sería el patrón que se repetiría un par de centurias después en el conjunto de la Casa del Obispo, e incluso apuesta por un modelo similar en el caso de los dos sarcófagos antropoides. Tuviera una funcionalidad funeraria o estrictamente ritual, lo cierto es que esa zona quedaría ya fuera de los límites estrictos de la ciudad como tal.

También al norte, algo más alejado y separado del espacio habitativo por un curso de agua estacional hoy perdido, se halla lo que hasta el momento puede ser el único ejemplo de enterramiento arcaico en el área insular de Gadir. La estructura excavada en la c/ Hércules, defendida como tumba por sus excavadores, presenta una serie de problemas en los que por tiempo y espacio no podemos entrar, pero que la alejan, por una parte, de los habituales campos de urnas característicos de los cementerios fenicios "planos" arcaicos (tipo Tiro-Al Bass o Ayamonte), pero también de los típicos enterramientos "locales, indígenas o tartésicos" (como los queramos llamar) y, por supuesto, de las clásicas tumbas aristocráticas.

En suma, defendemos que la primitiva ciudad de Gadir se situó al sur de la isla de Erytheia sobre una suave elevación natural (Fig. 21). En el punto topográfico más alto actual se emplazaría la posible acrópolis o área pública. La áreas residenciales se extenderían por sus flancos (como demuestra el importante sector de viviendas excavado) hasta llegar al paleocauce del canal Bahía-Caleta por el sur y el este, donde se localizan los límites periurbanos de funcionalidad económica. La ciudad posiblemente se extendería por el oeste y por el norte, aunque no tenemos certeza de ello y, en cualquier caso, tampoco debió alcanzar una gran superficie, habida cuenta que las recientes intervenciones llevadas a cabo en el Colegio Mayor Universitario (al noroeste) han proporcionado restos fenicios, al menos desde el s. VII a. C., procedentes de un contexto de posible funcionalidad votiva que recuerda al de c/ Ancha 29 (fosa y pozo), aunque algo posterior cronológicamente (Sáez et alii 2019). El límite norte, a su vez, queda definido por un espacio no urbanizado aunque sí ocupado, donde tendrían lugar actividades de tipo ritual en relación con la posible necrópolis de la ciudad (c/ Ancha) y por el propio cementerio (c/ Hércules).

En cuanto a los datos procedentes del extremo septentrional de la isla de Kotinoussa son, en líneas generales, posteriores cronológicamente. Posiblemente se trate de un área de expansión urbana o periurbana a partir de los ss. VII-VI a. C., con una funcionalidad industrial, portuaria o relacionada con los templos próximos (Niveau de Villedary e. p.). Los posibles restos constructivos y materiales pueden interpretarse como barrios periféricos o como instalaciones extraurbanas industriales relacionadas con las actividades portuarias, rituales, etc. En cualquier caso, no parecen formar parte del núcleo habitacional principal, situado al norte del canal. A partir de finales del s. VII a. C. la zona situada más al sur se comienza a utilizar como cementerio (Torres 2010: 56).

El carácter portuario del enclave quedaría reforzado por la existencia de dos puertos exteriores: uno abierto al Atlántico (playa de La Caleta) y otro a la bahía (en la ubicación del puerto actual) y al menos otros tres interiores: dos fondeaderos de poco calado en el frente abierto al océano Atlántico y, el más importante, el kothon o puerto interior situado en la zona de la moderna Catedral (Arteaga y Roos 2002). 


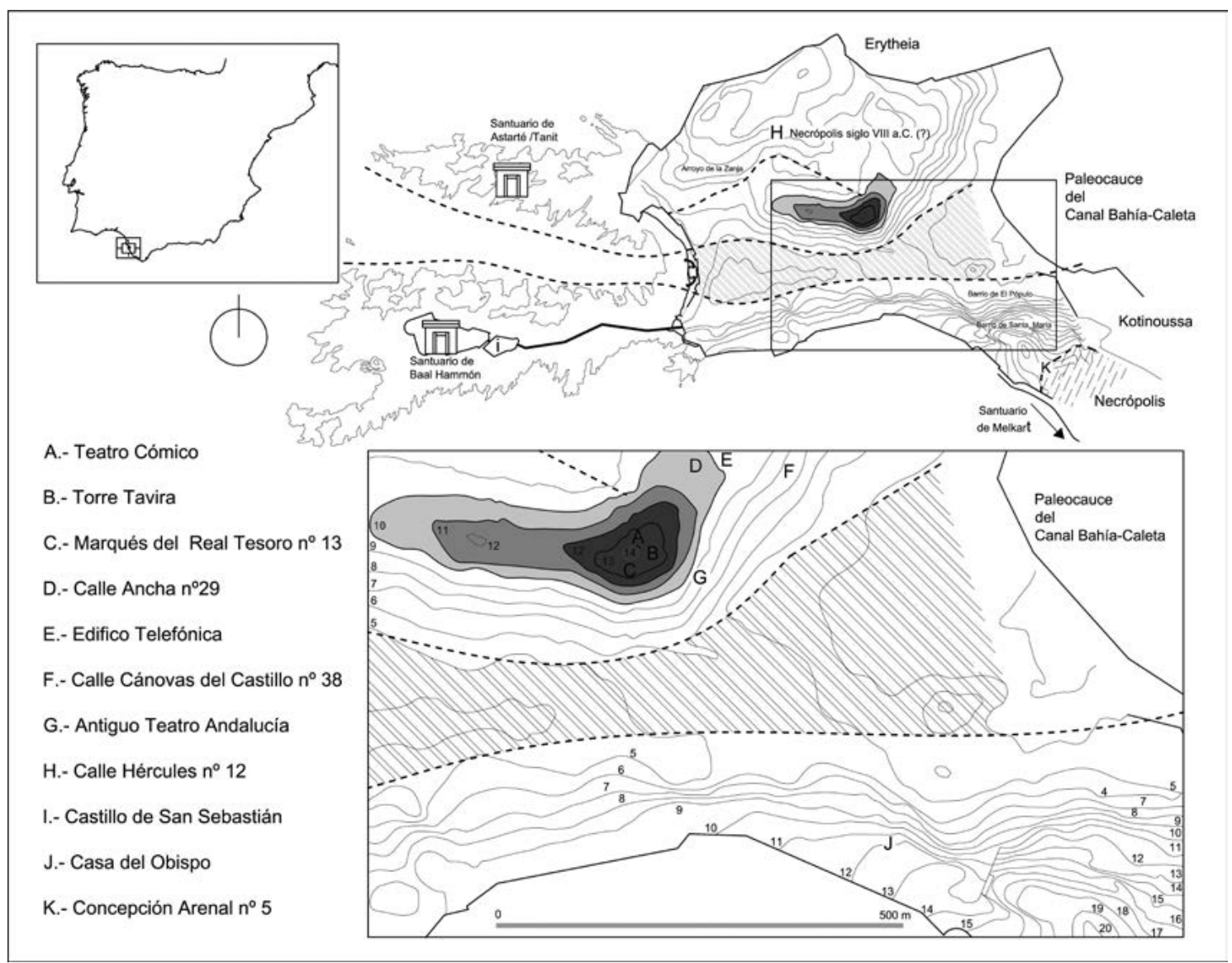

1

Figura 21. 1. Extensión probable del núcleo urbano primitivo de Erytheia con la localización de los puntos excavados y los elementos principales en época arcaica (@) autora, modificado a partir del plano original cortesía de J. M. ${ }^{a}$ Gener Basallote). 2. Distancia entre los diferentes sitios excavados o que han proporcionado materiales fenicios arcaicos (@ autora, modificado a partir de Ruiz Mata 2016: 314; fig. 4).

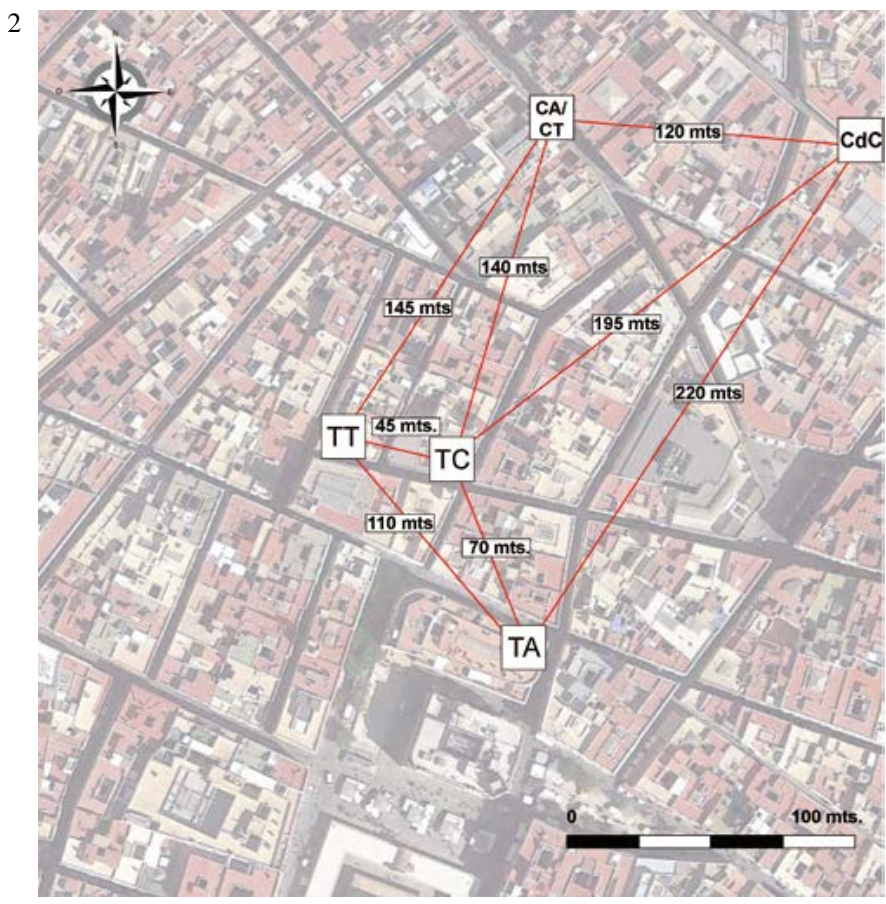


Junto a los templos clásicos citados por las fuentes y situados en los extremos septentrionales de ambas islas, junto a la boca occidental del canal (al norte el dedicado a Astarté y al sur el Kronion de las fuentes), otra posible zona con carácter sagrado es el entorno de la Catedral actual, en la isla mayor. Dicho espacio sabemos que se sacraliza con seguridad a partir de finales del s. VI a. C. cuando empiezan a realizarse ofrendas y pequeños banquetes alrededor de un enterramiento monumental apartado de la necrópolis habitual (Gener et alii 2014a). Los restos arcaicos documentados bajo esta estructura son interpretados como espacios domésticos por sus excavadores, pero no hay que descartar sin más el carácter religioso de los mismos, habida cuenta tanto de la continuidad sagrada del espacio como de la propia posición topográfica destacada del conjunto, así como de la presencia de algunos elementos materiales destacables - concretamente un vaso "tipo Carambolo"- (Niveau de Villedary e. p.).

Por su parte, Diego Ruiz Mata defiende que los datos aún son demasiado parciales y limitados como para establecer un orden lógico, funcional y secuencial de los espacios arqueológicos habitados y apuesta por la existencia de un hábitat insular disperso (Ruiz Mata et alii 2014: 92). Aunque no excluye que la primera fundación tiria se situara en el entorno del Teatro Cómico, defiende que la extensión urbana de este núcleo fue siempre muy pequeña, delimitada en las proximidades por zonas de ocupación de funcionalidad diversa (económica y religiosa/funeraria/ritual) y con secuencias estratigráficas cortas; incluso en el caso de la secuencia más prolongada, la del Teatro Cómico, donde la ocupación del sitio solo se prolonga durante tres siglos (Ruiz Mata 2016: 309-310). Para este investigador la explicación a la escasa entidad del núcleo insular deriva directamente de su concepción de la ciudad en estos primeros siglos, de acuerdo a la tesis que ya planteó hace casi dos décadas. Su hipótesis es que por "Gadir se entiende a varios núcleos de la Bahía, siendo el templo de Melqart -el dios protector de Tiro-, el centro religioso de este espacio, la conciencia de la pertenencia al lugar originario, y al mantenimiento de rituales que comportan la cohesión social y el sustento de la ideología y de los comportamientos éticos y sociales" (Ruiz Mata 2016: 315). En este esquema el centro económico básico lo constituye el Castillo de Doña Blanca mientras que el núcleo insular se caracteriza por "su carácter simbólico y representativo de su centro de origen, un papel específico religioso y político, que se mantuvo en la memoria colectiva a lo largo del tiempo" (Ruiz Mata 2016: 315) (Fig. 22). Carácter dual en el que insiste en su último trabajo (Ruiz Mata 2018: 267 y 276).
En sentido similar, Aurelio Padilla ya había sugerido unos años antes (2014) la posibilidad de que las viviendas excavadas en el Cómico, al menos las correspondientes al último nivel de habitación (el Fenicio $\mathrm{C}$ de sus editores), respondieran a las estructuras y habitaciones anexas a algún tipo de edificio de funcionalidad cultual (si no a algunas dependencias del propio santuario) debido a la documentación de una serie de rasgos característicos de los edificios de estas tipologías: existencia de pavimentos de conchas, las dimensiones de algunas estancias, la presencia de posibles altares centrales en las mismas y bancos corridos con lámparas dispuestos sobre ellos. Incluso otros hallazgos, como los productos almacenados en diferentes habitaciones consideradas como despensas, las propias huellas de bóvidos y de otras especies en los pavimentos de las calles (que interpreta como la de los animales en procesión llevados a inmolar) le llevan a insistir en esta interpretación (Padilla 2014: 30). La teoría puede ser sugerente, pero los argumentos, frente a los de los excavadores y editores del sitio, adolecen de suficiente peso. Mediante este discurso, la intención de Padilla no es sino reforzar las tesis de Ruiz Mata de la "capitalidad" fenicia occidental del asentamiento continental del Castillo de Doña Blanca, por una parte, y del carácter sagrado de la isla, por otro (Padilla 2014: 31).

La interpretación más novedosa se debe a José Luis Escacena, que en un trabajo reciente readapta el viejo patrón de asentamiento fenicio y lo trasplanta al tradicional territorio "tartésico" (Escacena 2018). Plantea este investigador que los establecimientos orientales (entendidos estos en su concepción más amplia que engloba tanto los tradicionales asentamientos fenicios como los secularmente considerados tartésicos u orientalizantes) se sitúan siempre -como había quedado demostrado para la costa malagueña a finales de los años 70- en las desembocaduras de los ríos, lo que facilita la penetración al interior, pero también el total control de la movilidad y del trasiego en ambos sentidos, curso arriba (hacia el hinterland) y curso abajo, hacia mar abierto, es decir tanto la salida como la entrada natural de los productos y mercancías; pero no solo de estas, sino también de gentes, tecnologías e ideas, entre otros elementos; una vez invalidado el "factor comercial" como el motivo principal de la implantación de poblaciones orientales en el lejano Occidente (Escacena 2018: 143).

Observa que la población se sitúa siempre en la margen occidental del curso de agua mientras que en la orilla contraria se levantan espacios sagrados (Fig. 23) que refrendan y dan cobertura ideológica a la apropiación del terreno y al establecimiento de poblaciones en principio foráneas (otro asunto es lo rá- 


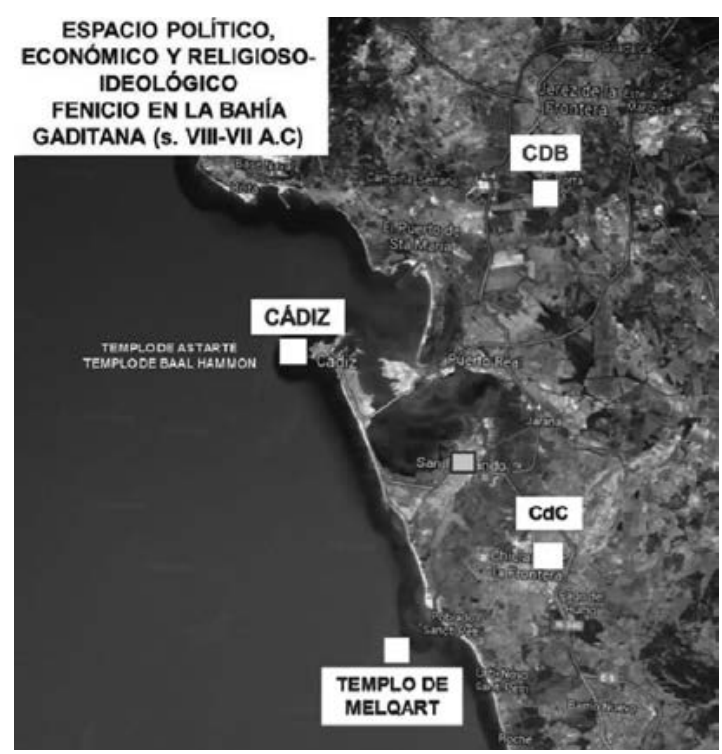

Figura 22. Espacio político, económico y religioso de Gadir y la bahía de Cádiz en época arcaica (Ruiz Mata 2016: 315; fig. 5).

pidamente que estas poblaciones dejan de ser forasteras para convertirse en locales, de segunda generación o como queramos llamarlas, pero eso es ya otra historia). Se trataría en palabras del propio Escacena de centros habitacionales de funcionalidad portuaria separados por un río de los santuarios, un conjunto que representaría un todo político y administrativo (aquí recoge el modelo plural de Ruiz Mata, por ejemplo 2016: 311) que controlaba económica y simbólicamente la entrada al interior y, por consiguiente, a los recursos del hinterland, especialmente interesantes para los colonos (tierras de cultivo, productos, minerales, mano de obra, etc.) (Escacena 2018: 144). Este modelo se repite en muchas de las desembocaduras de los ríos más occidentales como el Guadalquivir (Spal/ Carambolo), el Guadiana (Ayamonte/Castro Marim) y el Tinto/Odiel (Onuba/Aljaraque). Se trata en definitiva, como el propio autor reconoce, de releer en "clave oriental" lo que desde hace años se leía en "clave orientalizante" (Escacena 2018: 141).

En cuanto al territorio netamente gaditano, y a pesar de que no duda de la premisa de que el río Guadalete cumple la misma función delimitadora y de entrada al territorio que se reconocía en los casos del Guadalquivir y el Guadiana, Escacena cree que la ecuación es más compleja que en los ejemplos anteriores (Escacena 2018: 147). No deja de señalar con acierto que, por diversas causas, conocemos peor los yacimientos de la zona y sus dinámicas, pero por otra parte, no menos importante, subraya que la propia configuración paleogeográfica del archipiélago original y los mecanismos de transformación del mismo y de la propia bahía gaditana no se conocen aún lo suficiente, pese a los avances llevados a cabo, pues hubo de ser mucho más rápido, dinámico y profundo de los que tradicionalmente se ha valorado, influyendo los tiempos de manera decisiva en la propia configuración y evolución dinámica del paisaje cultural; tiempos y ritmos que intuimos, pero desconocemos con exactitud.

Por último, valora un aspecto que no se había tenido en cuenta hasta ahora: las corrientes mareales y
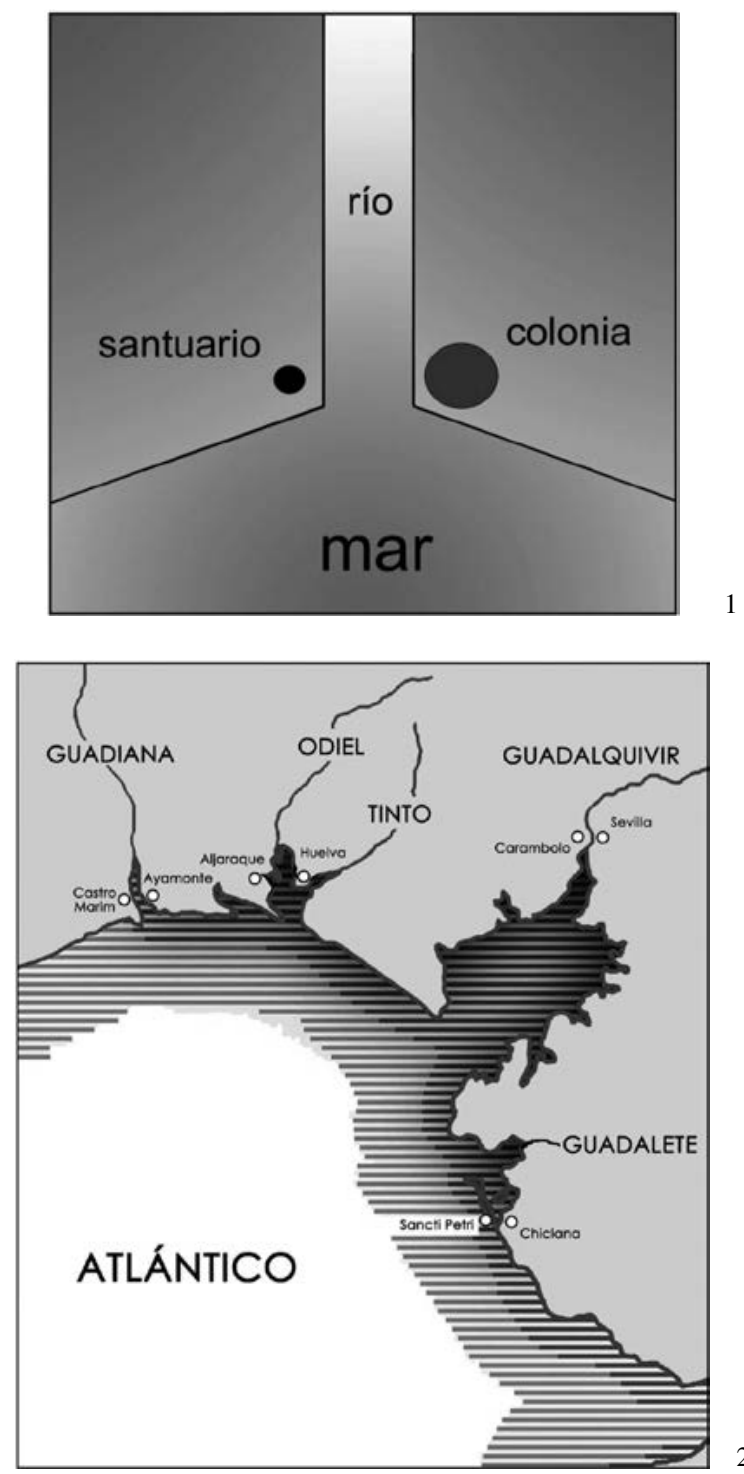

Figura 23. 1. Modelo teórico de la ocupación fenicia de las costas del Suroeste ibérico (Escacena 2018: 144; fig. 1). 2. Ocupación fenicia de las costas del Suroeste ibérico de acuerdo al patrón planteado: asentamiento (orilla este) - vía de agua santuario (orilla oeste) (Escacena 2018: 165; fig. 9). 
el régimen de vientos dominantes, en una zona donde Levante y Poniente se alternan (Escacena 2018: 147) alterando de forma decisiva aspectos de la vida marítima cotidiana aún en la actualidad. En función de este régimen cambiante de vientos propone que el acceso a la bahía se efectuara de forma habitual por la zona sur, es decir por el actual Caño de Sancti Petri, entre el extremo meridional de la antigua isla de Kotinoussa (donde la tradición, la historiografía y algunos hallazgos arqueológicos sitúan el templo de Melqart), en cuya orilla continental se sitúa el segundo de los asentamientos urbanos-portuarios conocidos por el momento: el del Cerro del Castillo. Lo que Escacena denomina "Puerta Sur" a la bahía (Escacena 2018: 148), sería la entrada habitual utilizada por las embarcaciones que arribaran desde el este cuando arreciase el Levante, viento que es el dominante durante los meses en los que es posible la navegación. De ahí que plantee, de acuerdo al modelo propuesto con anterioridad, que el principal santuario fenicio arcaico, el dedicado a Melqart, se situase al oeste del acceso sur.

Hasta ahí el modelo se ajusta al mayoritariamente aceptado, es al proponer que la ciudad original estuviese en la otra orilla cuando se aparta del mismo, pues admitir este esquema conllevaría retrotraer, al menos hasta el s. IX a. C., el origen del asentamiento amurallado del Cerro del Castillo (situado en la parte este del curso de agua), y por consiguiente, apostar por la naturaleza fenicia del sitio desde su propia fundación ex novo (sobre la que aún existen muchas dudas) y que se tratase, en esencia y sobre los otros dos centros habitacionales y portuarios conocidos: el continental (Castillo de Doña Blanca) e incluso el insular (cuyos restos mejor conocidos hasta el momento son los exhumados en el Teatro Cómico), de la Gadir prístina y original. En sus propias palabras "la más antigua aplicación del topónimo Gadir" (Escacena 2018: 148).

La teoría, si bien sugerente y "rompedora" como nos tiene acostumbrados José Luis Escacena, plantea, como él mismo reconoce, una serie de problemas que deben ser desarrollados con mayor profundidad (Escacena 2018: 148-149); sobre todo en relación a la fundación en la zona norte de un segundo asentamiento para que actuara de puerto de entrada directo hacia el interior a través del río Guadalete: El Castillo de Doña Blanca (Escacena 2018: 149), hecho que hubo de suceder en un momento temporal próximo a la que él propone que pudo ser la fundación original, que sitúa, como hemos visto, al sur (en contra Ruiz Mata, quien apuesta por la importancia del enclave continental septentrional desde un primer momento, considerándolo el gran puerto internacional de la bahía, vid. 2016: 312-313).
En su propuesta se suma a quienes defienden que el sector excavado en el Teatro Cómico pudiera responder, como sostienen otros investigadores (Padilla 2014: 30), a dependencias anexas al no lejano santuario de Astarté (Escacena 2018: 149), en una isla caracterizada por su función simbólico-religiosa, más que habitativa (Ruiz Mata 2016: 309).

\section{A MODO DE SÍNTESIS ¿CIUDAD REAL O TRADICIÓN INVENTADA?}

A lo largo de nuestro discurso hemos insistido en que la idea que hoy tenemos de Gadir es el resultado de una construcción historiográfica, en gran parte inventada, que surge desde la propia Antigüedad (Delgado 2008: 385) pero que no responde exactamente a la realidad.

La falta de atención de los autores antiguos hacia el Extremo Occidente se ha explicado por razones de lejanía y, sobre todo, por un desinterés general de los pueblos griegos hacia esta parte del mundo; que posibilitó que, paradójicamente y al mismo tiempo, la leyenda de la antigüedad de la ciudad fuera creciendo. A su vez, ambas circunstancias han terminado por investir a la ciudad de un "prestigio" institucionalizado e interiorizado a lo largo de los siglos pero, en gran parte, fabricado ad hoc (Hobsbwan y Ranger 2002), del que es muy difícil desprenderse a la hora de acometer un análisis histórico científico de la ciudad fenicia.

Si la secular falta de datos alimentó la leyenda aun en momentos recientes, contribuyendo a envolver en un halo de misterio todo lo que rodeaba al pasado más lejano de la colonia extremo-occidental (valga recordar el éxito de ciertas teorías como la de la "ciudad engullida por el mar") ${ }^{20}$, el descubrimiento de vestigios fenicios arcaicos en el subsuelo gaditano no ha zanjado la cuestión.

En ese momento se diferenciaban dos posturas historiográficas, tradicionalmente enfrentadas: quienes defendían a toda costa el emplazamiento de la ciudad antigua bajo la actual, en territorio insular, con base a la tradición (fundamentada, a su vez, en los testimonios literarios clásicos) y a la continuidad toponímica y urbana en épocas romana y posteriores; y aquellos que abogaban por una ciudad plural, a partir de los hallazgos en territorio continental (fundamentalmente los procedentes del Castillo de Doña Blanca) y en otras zonas de la bahía. Para estos últimos, el núcleo insular tradicional habría sido sobrevalorado históricamente.

${ }^{20}$ Todavía recogida en publicaciones de aparición reciente. Vid. Abad y Corzo 2017: 99-100. 
Frente a lo que cabría esperar, los hallazgos recientes no han hecho sino aumentar las diferencias entre ambas, radicalizándose las posiciones en muchos casos. Para los partidarios de la primera posibilidad, el descubrimiento de un buen número de contextos fenicios arcaicos en territorio insular, incluyendo la primera secuencia urbana, no hace sino refrendar (con argumentos ahora incontestables) lo que se venía defendiendo históricamente, sin reconocer la debilidad de la argumentación anterior que incurría, de hecho, en una falacia ad antiquitatem.

Los partidarios de la segunda posición, cuyo origen hay que buscarlo en gran parte en razonamientos ex silentio y ad ignorantiam ante la secular exigüidad del registro insular, se resisten, una vez halladas evidencias materiales objetivas, a cambiar su argumentación, que buscan acomodar al nuevo paradigma (el de la "ciudad dual en un territorio plural"), cayendo en el mismo error que se denunciaba.

En este "enfrentamiento" en ocasiones se olvida que la constatación de la ciudad insular (sea cual sea sus dimensiones, entidad y funcionalidad) no anula la hipótesis del poblamiento polinuclear alrededor de la bahía, sino que, por el contrario, contribuye a reforzarla.

Volviendo al punto de partida, creemos que esto es debido a que la fundación prístina de Gadir es uno de esos topos enraizados, tanto en el imaginario colectivo como en la investigación histórica, en los que la construcción de la tradición pesa aún más que el análisis científico y objetivo de la información ${ }^{21}$.

Lo cierto es que a día de hoy la realidad insular revela la existencia de un área urbana localizada bajo la actual ciudad, de características netamente levantinas, por ahora sin evidencias de estar amurallada, de dimensiones reducidas, que no debió extenderse mucho más allá de los límites conocidos; junto a ella se han constatado una serie de espacios sin construcciones edilicias permanentes y funcionalidad diversa (económica: comercial, portuaria y pesquera, ritual/ votiva, cultual y funeraria). Un panorama impensable hace solo veinte años, pero muy lejos aún de la esplendorosa "ciudad imaginada".

Ampliando el análisis al resto de la bahía, el paisaje fenicio se completa con una red de asentamientos fenicios de características urbanas (amurallados en este caso), templos, santuarios e implantaciones industriales que muestran la organización y apropiación del territorio, real y simbólicamente, desde momentos tempranos. Sin lugar a dudas y como ocurre en el resto del Mediterráneo, la ciudad no puede en-

\footnotetext{
${ }^{21}$ Otro caso paradigmático resulta la construcción (ficticia) de Tartessos. Entre otros muchos: Ferrer y Prados 2013.
}

tenderse sin el territorio ni este sin el asentamiento insular.

El reto está en articular toda esta información (¿creando nuevos modelos interpretativos actualizados que integren los nuevos datos?), por lo que en el punto actual el principal obstáculo es más mental que real. Persiste la imagen falseada del gran orbe, la ciudad esplendorosa y milenaria creada de forma ficticia. La tendencia a la idealización, a la ciudad deseada y soñada, pesa aún demasiado como para romper definitivamente con el modelo imaginado, con la "tradición inventada". Para poder seguir avanzando en el conocimiento de la Gadir real, la que fue, no la que se ha "imaginado", es necesario sacudirse los prejuicios en las dos direcciones. En este sentido, en los últimos años se observa una preocupante tendencia (desde el punto de vista histórico) a teñir de ese mismo espíritu legendario, con cierto aire de misterio, a la que se rebautiza (valga la paradoja) como "protagonista silente" o "ciudad sin nombre", en referencia a la damnatio memoriae sufrida en la Antigüedad por el actual asentamiento del Castillo de Doña Blanca, seguramente como represalia por su condición de plaza fuerte cartaginesa o pro-cartaginesa en el segundo conflicto romano-cartaginés (Ruiz Mata 2018: 266-267); dejando la duda en el aire de si este hecho fue el causante del traslado del topónimo o, al menos, de la restricción de su uso a territorio insular a partir de esos momentos ${ }^{22}$. Ruiz Mata no deja de tener parte de razón, pero al plantear el tema en los términos en los que lo hace ("arrinconada en la historia", "muerte en vida", "trágico final") se corre el peligro de convertir un problema histórico real: el desconocimiento del nombre antiguo de la ciudad continental (y las razones de ello), en una nueva "tradición inventada".

Por esta razón, porque existe el riesgo de volver a los antiguos paradigmas, es por lo que insistimos en la necesidad de construir (de forma consciente) nuevos modelos explicativos y abandonar definitivamente los antiguos axiomas.

22 “No pasó por Cádiz ningún geógrafo investigador, erudito e historiador curioso que se preguntase cuál fue el nombre de esa ciudad, cuál fue su historia y la transmitiese? Cuando algo se ve tan manifiesto a la vista, tan cerca de Cádiz o navegando, y se oculta, la razón no puede ser otra que política y estratégica, de olvido intencionado. Lo supongo, pero no dispongo de textos que lo confirmen. Sabemos que los informes fenicios y púnicos, que debió haberlos, se hallan perdidos, e ignoramos lo que se escribió de ella y cuál fue nombre fenicio, aunque solo fuesen asuntos de negocios o simples anécdotas de marinos y comerciantes. Pero ¿y los más tardíos grecorromanos con objetivos más científicos? A veces el silencio es una respuesta explícita en el conjunto de los datos tangibles. Un modo de borrar el pasado de algo que molesta" (Ruiz Mata 2018: 267) 


\section{APÉNDICE I}

Paz Pasamar, Pilar, "La dama de Cádiz"23, Historias bélicas, 2012, Sevilla, pp. 35-39.

[...] Todos se hacen a un lado para dejar paso a los hombres que habrán de transportar el sarcófago, después de remachar a golpe de martillo los clavos sobre la madera. Al mismo tiempo, desde el huerto, comienza a oírse un cántico funeral acompasado y grave. Las voces se pierden con el viento de levante:

El padre Sol

se acuesta en el mar

y su esposa Baant arregla el lecho

de las aguas

para que el sueño del esposo sea tranquilo.

Baant extenderá su negro velo

sobre los que hemos vivido un día de luz.

La luz que nos donó el Padre Sol

que ahora se acuesta sobre el mar...

Alrededor del foso, ya asentados los sillares y el sarcófago de mármol en posición vertical, iluminado por la luz de las teas, los familiares, jornaleros y esclavos se sitúan respetando el orden jerárquico.

[...]

A ver, dame. Qué asco. Tengo escalofríos, que metí la mano en eso que me parese que es una tumba de las romanas, que hay por toas partes, y tú ya ves cómo me he puesto. habrá que avisar a Dragaos y al Museo y a la policía municipal. tú niño, légate a la Oriental y llama, llama a toas partes y de paso me tares un sentenario que me hase farta, a la vuelta, claro. ¿Cómo voy a darte si tengo la mano empringá? Ya haremos cuentas.

Cómo se va a poner la parienta cuando me huela. Hasta las trancas, digo, y el joío levante. Me vi dá un baño en la Caleta... En fin de semana en remojo, digo... Mira, mira, tú, oye, qué cosa más grande, toa grande, toa de mármol. Ven pacá. Aquí está la tapa, y rota por los pies... No, si el golpetazo ha sío de órdago tío. Maldita sea, que nos van a paralisar ahora, que te juro por mi mare que es algo grande y de importancia. Una pieza de una vé. ¡Pero baja ya de la cabina! Por aquí, dame, qué asco. A ver qué dicen, que esto trae cola, te lo digo yo. Esto tiene que valé una jartá. es una señora y de guapa, no veas. No, si los romanos sabían hacer las cosas. Mira qué rizos, como los de la parienta cuando se coge los rulos, igualito. Es guapa de verdá... ¡La de fotos que va a echarle el Jumán cuando se enteren los del diario por

${ }^{23}$ Recuperado de: http://cuadernodecadiz.blogspot. com/2012/05/el-cadiz-fenicio-y-sus-sarcofagos-en-la.html. Consultado el 1 de noviembre de 2018. aquí y por allá! Pero al que le va a dar algo es a Don Ramón como no llegue pronto. Y a ver si también vuelve el niño, qué le habrán dicho del Ayuntamiento, porque aquí no se puede haser ná por ahora, y la pringue no se me va ni frotando. Acércame otro botijo, hombre, Rafael, que ya he acabado con éste. Y, ahora, mucho cuidao con la cabeza, dejarla al borde de la tapa a ver qué nos mandan que hagamos... ¡No toquéis ná, digo!... Que esto se va a poner como el Carranza por el Trofeo, que ya vienen mirones... y lo que sobra en Cádiz son mirones ¡Qué nadie toque ná!

\section{APÉNDICE II}

"El error de la muralla", Diario de Cádiz, 9 de mayo de 2002, Editorial, p. 4.

Al final ha resultado que la supuesta muralla "fenicia" de la calle San Miguel, de Cádiz, era romana. Un error lamentable, aunque inducido por la certeza de un asentamiento de origen fenicio en la zona. En todo caso, este episodio es sintomático del trasfondo de la cultura local. En su día tanto la Junta como el Ayuntamiento elogiaron el hallazgo y se encargaron de difundir sus propios méritos, con ruedas de prensa por medio. Aprovechar el error para hacer política de revancha no viene a cuento. La falta de rigor en estos asuntos sin duda existe, y sería bueno que todos los agentes culturales reflexionaran sobre el papel que están representando.

\section{APÉNDICE III}

"Historia de un hallazgo de envergadura que nunca existió", Diario de Cádiz, 9 de mayo de 2002, p. 51.

El teniente de alcalde delegado de Cultura, Antonio Castillo, abogaba ayer por el "rigor científico" a la hora de hablar de los hallazgos arqueológicos. El motivo se dilucidaría poco después, cuando indicó que "algunas hipótesis adelantadas se quedaron en eso, en hipótesis" porque "no era lo que parecía que era". Hablando en cristiano, lo que Antonio Castillo quería indicar era que la muy renombrada muralla fenicia en realidad era una gran cisterna romana. Volvió entonces a pedir "prudencia y rigor científico", mientras aludía, veladamente, a aquel arqueólogo que, en su día, adelantó la noticia de un hallazgo que, dos días después, y en rueda de prensa, el propio Antonio Castillo calificaba como importantísimo. Las prisas, en todos los casos, siempre son malas consejeras. 


\section{BIBLIOGRAFÍA}

Abad Casal, L. y Corzo Sánchez, R. 2017: “Gadir/ Gades/Cádiz. Muchas novedades pendientes de una interpretación global", M. M. Ros Sala (ed.), Conviviendo con la Arqueología: Las capitales de las grandes potencias Mediterráneas en la Antigüedad. Una mirada alternativa, Phicaria V, Murcia, 87-103.

Álvarez Rojas, A. 1992: "Sobre la localización del Cádiz fenicio", Boletín del Museo de Cádiz V, 17-30.

Arteaga Matute, O. y Roos, A. M. 2002: "El puerto fenicio-púnico de Gadir. Una nueva visión desde la geoarqueología urbana de Cádiz”, Spal 11, 2139. https://doi.org/10.12795/spal.2002.i11.02

Blanco, F. J. 2002: Comentario de los resultados arqueológicos obtenidos del sondeo realizado en la C/Marqués del Real Tesoro, 13 (Cádiz). Memoria inédita depositada en la Delegación Provincial de Cultura de Cádiz.

Botto, M. 2014a: "Los fenicios en la Bahía de Cádiz: estrategias de poblamiento y de aprovechamiento del territorio, relaciones con el mundo indígena, comercio (siglo IX- finales del siglo VII/inicios del VI a.C.)", M. Botto (ed.), Los Fenicios en la Bahía de Cádiz: Nuevas investigaciones, Collezione di Studi Fenici 46, Roma-Pisa, 265-281.

Botto, M. (ed.) 2014b: Los Fenicios en la Bahía de Cádiz: Nuevas investigaciones, Collezione di Studi Fenici 46, Roma-Pisa.

Bueno Serrano, P. 2014: "Un asentamiento del Bronce Final - Hierro I en el Cerro del Castillo, Chiclana, Cádiz. Nuevos datos para la interpretación de $G a$ deira.)", M. Botto (ed.), Los Fenicios en la Bahía de Cádiz: Nuevas investigaciones, Collezione di Studi Fenici 46, Roma-Pisa, 225-251.

Caro Bellido, A. 1990-1991: "Gadir y su entorno", Anales de la Universidad de Cádiz 7-8 (I), 105-116.

Cobos, L., Muñoz, A. y Perdigones, L. 1995-1996: "Intervención arqueológica en el solar del antiguo teatro Andalucía de Cádiz: La factoría de salazones y la representación gráfica del Faro de Gades", Boletín del Museo de Cádiz. VII, 115-121.

Córdoba Alonso, I. y Ruiz Mata, D. 2005: "El asentamiento fenicio arcaico de la calle Cánovas del Castillo (Cádiz). Un análisis preliminar”, S. Celestino y J. Jiménez (eds.), El Periodo Orientalizante, Anejos de Archivo Español de Arqueología XXXV, Mérida, 2, 1269-1322.

Corzo Sánchez, R. 1980: "Paleotopografía de la bahía gaditana”, Gades 5, 5-14.

Corzo Sánchez, R. 1983: "Cádiz y la arqueología fenicia”, Anales de la Real Academia de Bellas Artes de Cádiz 1, 5-79.
Delgado Hervás, A. 2008: "Fenicios en Iberia", F. Gracia Alonso (coord.), De Iberia a Hispania, Madrid, 347-474.

Domínguez Monedero, A. 2012: "Gadir", C. Fornis (ed.), Mito y arqueología en el nacimiento de ciudades legendarias de la Antigüedad, Sevilla, 153197.

Escacena Carrasco, J. L. 1985: "Gadir", Aula Orientalis 3, 39-58.

Escacena Carrasco, J. L. 2018: "Huelva-Aljaraque y el patrón poblacional fenicio de la costa tartésica", P. Campos (ed.), Arqueología y territorio en la provincia de Huelva: veinte años de las Jornadas de Aljaraque, Huelva, 137-177.

Fernández Camacho, P. 2015: “A Space without Ethnology: Study of the Ideological Treatment of the West in Greek and Roman Literature through the Sources about the Island of Gades", L'Antiquité Classique 84, 63-73.

Fernández Camacho, P. 2016: "La ciudad bipolar. La construcción de la imagen de Cádiz en la historiografía del siglo XVI a través de las fuentes clásicas", Ágora. Estudos Clássicos em Debate 18, 193-215.

Ferrer Albelda, E. y Prados Pérez, E. 2013: “Tarteso, de ciudad a Imperio (o sobre la creeación de identidades ficticias)", J. M. Campos y J. Alvar (eds.), Tarteso. El emporio del metal, Córdoba, 395-414.

Fierro Cubiella, J. A. 1995: Gadir. Historia de un mito, Cádiz.

Frutos Reyes, G. y Muñoz Vicente, Á. 2004a: "La incidencia antrópica del poblamiento fenicio-púnico desde Cádiz a Sancti Petri”, G. Chic, G. De Frutos, Á. Muñoz y Á. Padilla (eds.), Gadir-Gades. Nueva perspectiva interdisciplinar, Sevilla, 5-69.

Frutos Reyes, G. y Muñoz Vicente, Á. 2004b: "La implantación colonial fenicia arcaica en el archipiélago de las Gadeira: una propuesta para el debate", Huelva en su Historia $2^{\mathrm{a}}$ Época 11, 83106.

Gabardón de la Banda, J. F. 2014, "La regulación del Patrimonio Arqueológico como dominio público a raíz de la promulgación de la ley de 1911: un antecedente de la Ley 16/1985", Anuario Jurídico y Económico Escurialense XLVII, 263-284.

Gener, J. M., Navarro, M. A., Pajuelo, J. M., Torres, M. y Domínguez-Bella, S. 2012: "Las crétulas del siglo VIII a. C. de las excavaciones del solar del Cine Cómico (Cádiz)", Madrider Mitteilungen 53, 134-186.

Gener, J. M., Jurado, G., Pajuelo, J. M. y Torres, M. 2014a: "El proceso de sacralización del espacio en Gadir: el yacimiento de la Casa del Obispo (Cádiz). Parte I", M. Botto (ed.), Los Fenicios en la 
Bahía de Cádiz: Nuevas investigaciones, Collezione di Studi Fenici 46, Roma-Pisa, 123-155.

Gener, J. M., Navarro, M. A., Pajuelo, J. M., Torres, M. y López, E. 2014b: “Arquitectura y urbanismo de la Gadir fenicia: el yacimiento del 'Teatro Cómico' de Cádiz”, M. Botto (ed.), Los Fenicios en la Bahía de Cádiz: Nuevas investigaciones, Collezione di Studi Fenici 46, Roma-Pisa, 14-50.

Higueras-Milena, A. y Sáez Romero, A. M. 2013: "Aplicación experimental de técnicas geofísicas para la localización, investigación y difusión del patrimonio arqueológico en la zona de La Caleta (Cádiz)", X. Nieto, A. Ramírez y P. Recio (eds.), Navegación y comercio en la Antigüedad. I Congreso de Arqueología Náutica y Subacuática Española, Madrid, 992-1007.

Hobsbawn, E. y Ranger, T. 2002: La invención de la tradición, Barcelona.

Jiménez Cisneros, M. J. 1971: Historia de Cádiz en la Antigüedad, Cádiz.

Lavado, M. L., Molina, M., Cobos, L., Blanco, F. y Sibón, F. 2000: "El asentamiento antiguo de Cádiz a través de las últimas excavaciones arqueológicas", Actas del IV Congreso Internacional de Estudios Fenicios y Púnicos II, Cádiz, 869-879.

Llave, E., Hernández-Molina, F. J., Alonso Villalobos, C., Gallardo Abarzuza, M., Vázquez, J. T. y López-Aguayo, F. 1999: “Caracterización y evolución del paleocauce del río Guadalete en la bahía de Cádiz durante el cuaternario terminal”, Geogaceta 26, 43-46.

López Castro, J. L. 1992: "La colonización fenicia en la Península Ibérica: 100 años de investigación”, Actas del Seminario La colonización fenicia en el sur de la Península Ibérica. 100 años de investigación, Almería, 11-79.

López Castro, J. L. 2006: "Colonials, merchants and alabaster vases: the western Phoenician aristocracy", Antiquity 80, 74-88. https://doi.org/10.1017/ s0003598x00093273

López Castro, J. L. (ed.) en prensa: Entre Útica y Gadir. Navegación y colonización fenicia en Occidente a comienzos del I milenio AC.

Martín Ruiz, J. A. 2017: "Enterramientos fenicios arcaicos en el sur de la Península Ibérica (siglos IX-VIII a.C.)", Revista Atlántica-Mediterránea de Prehistoria y Arqueología Sociales 19, 115-130. https://doi.org/10.25267/rev_atl-mediterr_prehist_ arqueol_soc.2017.v19.08

Maya, R., Jurado, G., Gener, J. M., Torres, M., López, E. y Zamora, J. Á. 2014, "Nuevos datos sobre la posible ubicación del Kronion de Gadir: las evidencias de época fenicia”, M. Botto (ed.), Los Fenicios en la Bahía de Cádiz: Nuevas investigacio- nes, Collezione di Studi Fenici 46, Roma-Pisa, 156-180.

Muñoz Vicente, Á. 1995-1996: "Secuencia histórica del asentamiento fenicio-púnico de Cádiz: un análisis crono-espacial tras quince años de investigación arqueológica", Boletín del Museo de Cádiz VII, 77-105.

Muñoz Vicente, Á. 1998: "Notas sobre la necrópolis fenicia de Cádiz", Homenaje al Profesor Carlos Posac Mon, Ceuta, 131-141.

Muñoz Vicente, Á. 1999: "Gadir en el Castillo de Doña Blanca: Análisis crítico de una hipótesis", Revista de Historia de El Puerto 23, 55-64.

Muñoz Vicente, Á. 2004: "Nuevos hallazgos para el conocimiento del pasado fenicio en la ciudad de Cádiz", Ateneo 4, 67-70.

Muñoz Vicente, Á. y Perdigones Moreno, L. 2000: "Estado actual de la arqueología fenicio-púnica en la ciudad de Cádiz", Actas del IV Congreso Internacional de Estudios Fenicios y Púnicos II, Cádiz, 881-891.

Niveau de Villedary y Mariñas, A. M. 2008: "Estado de la cuestión y nuevas perspectivas de la arqueología púnica en la Península Ibérica: el caso de la bahía de Cádiz”, J. P. Vita y J. Á. Zamora (eds.), Nuevas Perspectivas II: La arqueología fenicia y púnica en la Península Ibérica, Cuadernos de Arqueología Mediterránea 18, Barcelona, 81-127.

Niveau de Villedary y Mariñas, A. M. 2010: “"Deconstruyendo' paradigmas. Una (re)visión historiográfica crítica al modelo interpretativo tradicional del Cádiz fenicio-púnico a la luz de los nuevos datos", E. Ferrer (ed.), Los Púnicos de Iberia: proyectos, revisiones, síntesis, Mainake 32-I, Málaga, 619-671.

Niveau de Villedary y Mariñas, A. M. 2014: "De colonia a ciudad. Algunos apuntes sobre la situación y naturaleza de la ciudad de Gadir", C. Ferrando y B. Costa (eds.), In amicitia. Miscel-lània d'estudis en homenatge a Jordi H. Fernández, Treballs del Museu Arqueològic d'Eivissa i Formentera 72, Eivissa, 485-515.

Niveau de Villedary y Mariñas, A. M. 2015: "La estructuración del espacio urbano y productivo de Gadir durante la Fase Urbana Clásica: cambios y perduraciones", Complutum 26-1, 225-242. https:// doi.org/10.5209/rev_cmpl.2015.v26.n1.49351

Niveau de Villedary y Mariñas, A. M. 2018: “Gadir revisited. A proposal for reconstruction of the Archaic Phoenician foundation", Vicino Oriente XXII, 91-109.

Niveau de Villedary y Mariñas, A. M. e. p.: "La Gadir arcaica: cronología, topografía y morfología urba- 
na”, J. L. López Castro (ed.), Entre Útica y Gadir. Navegación y colonización fenicia en Occidente a comienzos del I milenio AC, en prensa.

Padilla Monge, A. 2014: "Los inicios de la presencia fenicia en Cádiz", Gerión 32, 15-56. https://doi. org/10.5209/rev_geri.2014.v32.46664

Ponce Cordones, F. 2000: "Sobre la ubicación del Cádiz fenicio", Actas del IV Congreso Internacional de Estudios Fenicios y Púnicos II, Cádiz, 905-914.

Prados Martínez, F. 2007: Los Fenicios. Del monte Líbano a las columnas de Hércules, Madrid.

Ramírez Delgado, J. R. 1982: Los primitivos núcleos de asentamiento en la ciudad de Cádiz, Cádiz.

Rodríguez Muñoz, R. 2008: El hábitat fenicio-púnico de Cádiz en el entorno de la Bahía, BAR International Series 1778, Oxford.

Ruiz Mata, D. 1999: "La fundación de Gadir y el Castillo de Doña Blanca: Contrastación textual y arqueológica", Complutum 10, 279-317.

Ruiz Mata, D. 2016: "Las ciudades fenicias del Castillo de Doña Blanca y Cádiz durante el s. VIII a.C. Mi visión actual según los datos recientes", M. Botto et alii (eds.), Lo mio maestro e'l mio autore. Studi in onore di Sandro Filippo Bondì, Rivista di Studi Fenici XLIV, Roma, 305-318.

Ruiz Mata, D. 2018: "Gadir, su estructura plural. Un modo de ver su fundación fenicia en el espacio y en el tiempo", Onoba 6, 249-288. https://doi. org/10.33776/onoba.v0i6.3414

Ruiz Mata, D. y Pérez, C. J., 1995: El poblado fenicio del Castillo de Doña Blanca (El Puerto de Santa María, Cádiz), Biblioteca de Temas Portuenses 5, El Puerto de Santa María.

Ruiz Mata, D., Pérez, C. J. y Gómez, V. 2014: "Una nueva zona fenicia de época arcaica en Cádiz: el solar de la 'Calle Ancha, no 29'”, M. Botto (ed.), Los Fenicios en la Bahía de Cádiz: Nuevas investigaciones, Collezione di Studi Fenici 46, RomaPisa, 83-122.

Sáez Romero, A. M. y Belizón Aragón, R. 2014: "Excavaciones en la calle Hércules, 12 de Cádiz. Avance de resultados y primeras propuestas acerca de la posible necrópolis fenicia insular de $G a$ dir", M. Botto (ed.), Los Fenicios en la Bahía de Cádiz: Nuevas investigaciones, Collezione di Studi Fenici 46, Roma-Pisa, 181-201.
Sáez Romero, A. M. e Higueras-Milena Castellanos, A. 2016: "Cerámicas fenicias arcaicas de procedencia subacuática del área de la Caleta (Cádiz): ensayo de contextualización e interpretación histórica", Cuadernos de Prehistoria y Arqueología 42, 119-142. https://doi.org/10.15366/cupauam2016.42.004

Sáez Romero, A. M., Lara Medina, M. y Bernal Casasola, D. 2019: "Indicios de la ocupación feniciopúnica en la isla menor gaditana", D. Bernal, J. M. Vargas y M. Lara (eds.), 7 metros de la Historia de Cádiz... Arqueología en El Olivillo y en el Colegio Mayor Universitario, Cádiz, 169-235.

Sagona, C. 2004: "The Phoenicians in Spain from a central Mediterranean Perspective: A Review Essay", Ancient Near Eastern Studies 41, 240-266. https://doi.org/10.2143/anes.41.0.562930

Torres, M., Gener, J. M., Navarro, M. A., Pajuelo, J. M., y López, E. 2018: "Los materiales cerámicos de la fase II (820-750 a.C.) de las excavaciones efectuadas en el Teatro Cómico (Gadir/Cádiz)", M. Guirguis (ed.), From the Mediterranean to the Atlantic: people, goods and ideas between East and West. II. 8th International Congress of Phoenician and Punic Studies (Italy, Sardinia Carbonia, Sant'Antioco 21th-26th October 2013), Pholia Mediterranea 2, Pisa-Roma, 176-185.

Torres, M., López, E., Gener, J. M., Navarro, M. A. y Pajuelo, J. M. 2014: "El material cerámico de los contextos fenicios del 'Teatro Cómico' de Cádiz: un análisis", M. Botto (ed.), Los Fenicios en la Bahía de Cádiz: Nuevas investigaciones, Collezione di Studi Fenici 46, Roma-Pisa, 51-82.

Torres Ortiz, M. 2010: "Sobre la cronología de la necrópolis fenica arcaica de Cádiz", A. M. Niveau de Villedary y V. Gómez (eds.), Las necrópolis de Cádiz. Apuntes de arqueología gaditana en Homenaje a J. F. Sibón, Cádiz, 31-67.

Zamora, J. Á., Gener, J. M., Navarro, M. A., Pajuelo, J. M. y Torres, M. 2010: "Epígrafes fenicios arcaicos en la excavación del Teatro Cómico de Cádiz (20062010)", Rivista di Studi Fenici XXXVIII-2, 203-36.

Recibido: 12-11-2018

Aceptado: 11-03-2019 